Prepared in cooperation with the City of Aurora, Colorado Springs Utilities, Lower Arkansas Valley Water Conservancy District, Pueblo Board of Water Works, Southeastern Colorado Water Conservancy District, and Upper Arkansas Water Conservancy District

\title{
Characterization of Streamflow, Water Quality, and Instantaneous Dissolved Solids, Selenium, and Uranium Loads in Selected Reaches of the Arkansas River, Southeastern Colorado, 2009-2010
}

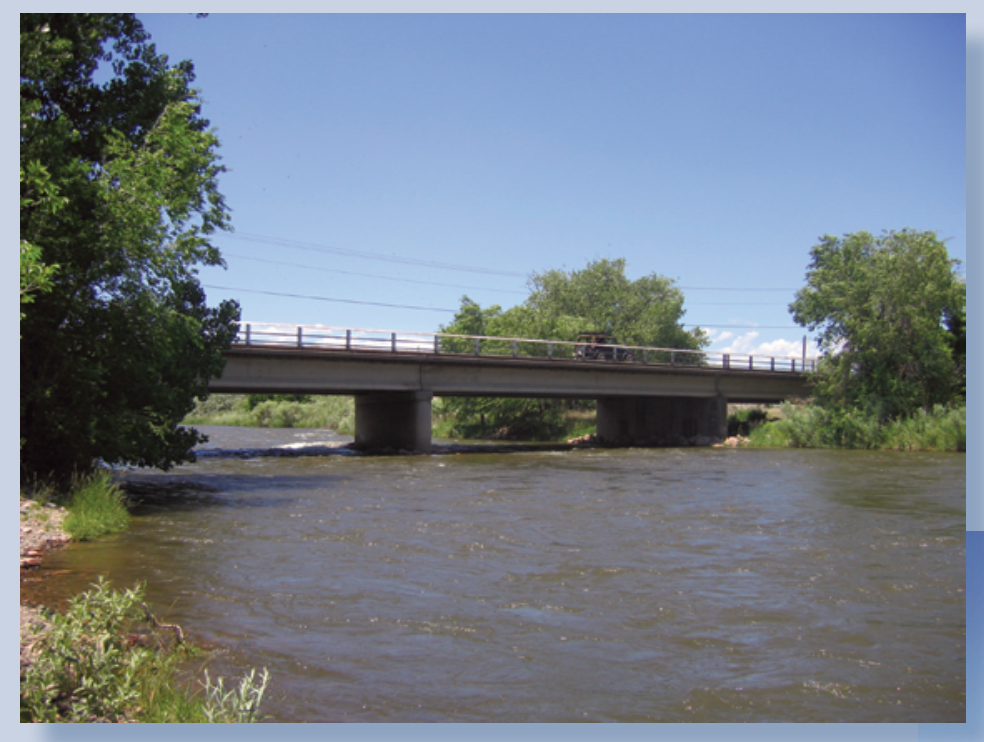

Scientific Investigations Report 2012-5234

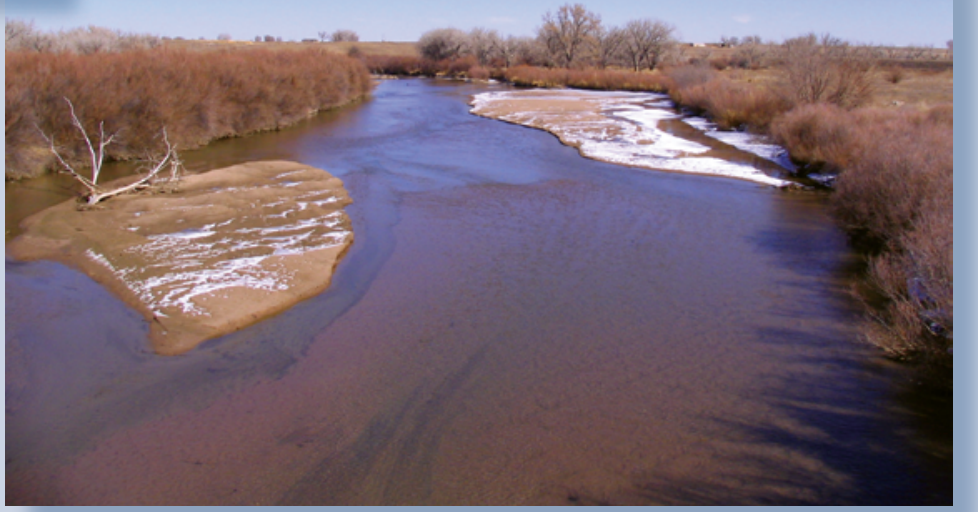


COVER. (1) Arkansas River at Fourmile Road, Canon City, Colorado (photo taken by Roderick Ortiz, U.S. Geological Survey, 6/19/2009). (2) Arkansas River at Swink, Colorado (photo taken by Roderick Ortiz, U.S. Geological Survey, 2/5/2010). 


\section{Characterization of Streamflow, Water Quality, and Instantaneous Dissolved Solids, Selenium, and Uranium Loads in Selected Reaches of the Arkansas River, Southeastern Colorado, 2009-2010}

By Tamara Ivahnenko, Roderick F. Ortiz, and Robert W. Stogner, Sr.

Prepared in cooperation with the City of Aurora, Colorado Springs Utilities, Lower Arkansas Valley Water Conservancy District, Pueblo Board of Water Works, Southeastern Colorado Water Conservancy District, and Upper Arkansas Water Conservancy District

Scientific Investigations Report 2012-5234 


\section{U.S. Department of the Interior \\ KEN SALAZAR, Secretary \\ U.S. Geological Survey \\ Marcia K. McNutt, Director}

U.S. Geological Survey, Reston, Virginia: 2013

For more information on the USGS - the Federal source for science about the Earth, its natural and living resources, natural hazards, and the environment, visit http://www.usgs.gov or call 1-888-ASK-USGS.

For an overview of USGS information products, including maps, imagery, and publications, visit http://www.usgs.gov/pubprod

To order this and other USGS information products, visit http://store.usgs.gov

Any use of trade, firm, or product names is for descriptive purposes only and does not imply endorsement by the U.S. Government.

Although this information product, for the most part, is in the public domain, it also may contain copyrighted materials as noted in the text. Permission to reproduce copyrighted items must be secured from the copyright owner.

Suggested citation:

Ivahnenko, Tamara, Ortiz, R.F., and Stogner, R.W., Sr., 2013, Characterization of streamflow, water quality, and instantaneous dissolved solids, selenium, and uranium loads in selected reaches of the Arkansas River, southeastern Colorado, 2009-2010: U.S. Geological Survey Scientific Investigations Report 2012-5234, 60 p. 


\section{Contents}

Abstract

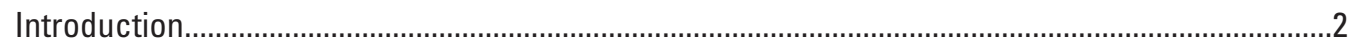

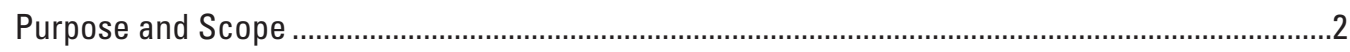

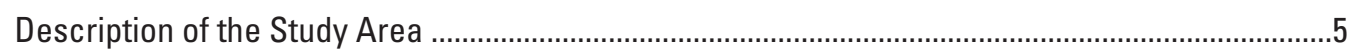

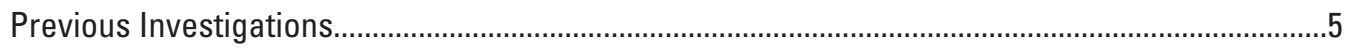

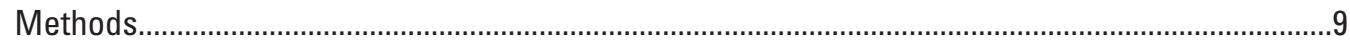

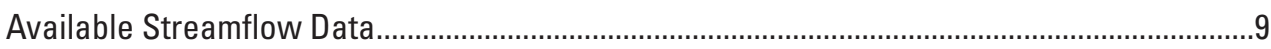

U.S. Geological Survey Streamflow Data .....................................................................

Colorado Division of Water Resources Streamflow Data .................................................

Wastewater Treatment Plant Streamflow Data..................................................................12

Available Continuous Water-Quality Monitor Data .................................................................12

Water-Quality Sampling Techniques and Analytical Methodology.........................................12

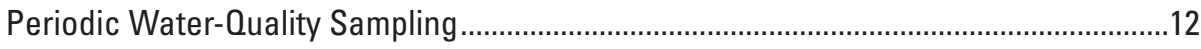

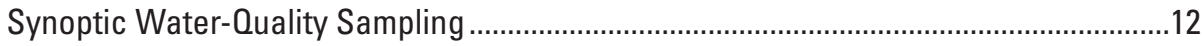

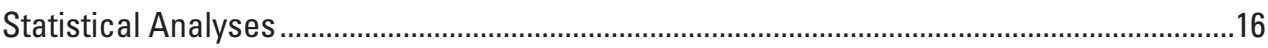

Quality-Assurance Procedures ..............................................................................................16

Characteristics of Streamflow, Water Quality, and Instantaneous Dissolved Solids, Selenium, and Uranium Loads in the Arkansas River Basin from Canon City to Near Portland .........23

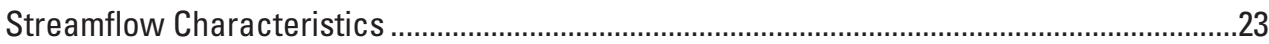

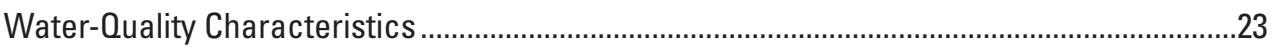

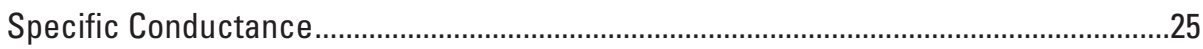

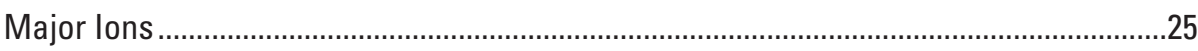

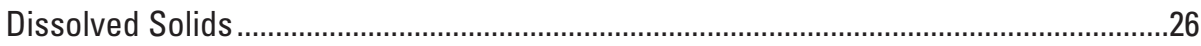

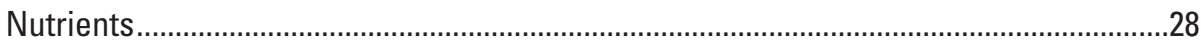

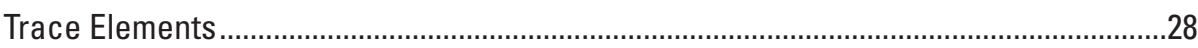

Hydrogen and Oxygen Isotopes ...........................................................................

Characteristics of Instantaneous Dissolved Solids, Selenium, and Uranium Loading ...........34

Characteristics of Streamflow, Water Quality, and Instantaneous Dissolved Solids, Selenium, and Uranium Loads in the Arkansas River Basin from Avondale to Las Animas ................39

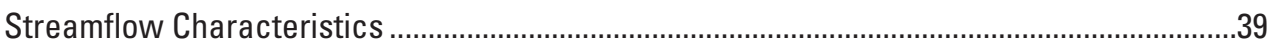

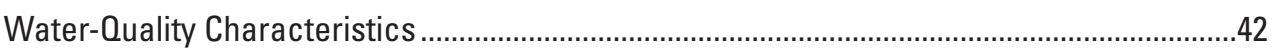

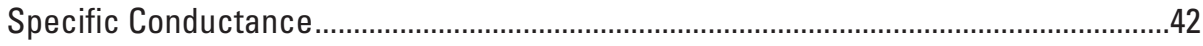

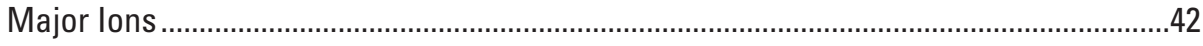

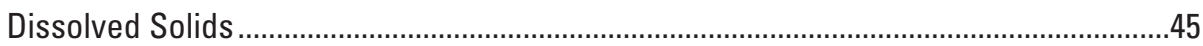

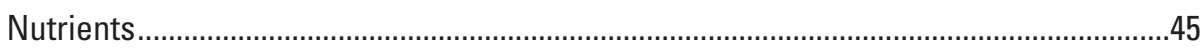

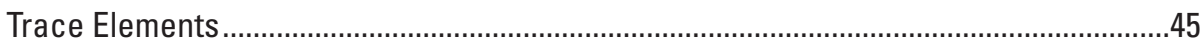

Hydrogen and Oxygen Isotopes ............................................................................51

Characteristics of Instantaneous Dissolved Solids, Selenium, and Uranium Loading ...........53

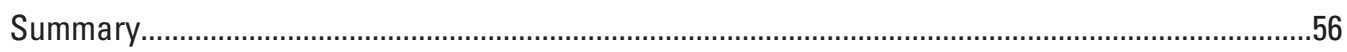

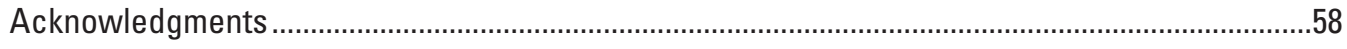

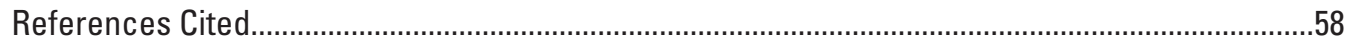




\section{Figures}

1. Location of the Arkansas River Basin in Colorado..

2. Delineation of the Upper Arkansas River Basin study area and locations of streamflow and water-quality sites, Canon City to Pueblo Reservoir, Colorado.

3. Delineation of the Lower Arkansas River Basin study area and location of streamflow and water-quality sites, Avondale to Las Animas, Colorado

4. Annual Arkansas River hydrographs (2010) (A) Arkansas at Portland, (B) Arkansas near Avondale, and $(C)$ Arkansas at Las Animas.

5. Streamflow hydrographs for $(A)$ Arkansas River at Canon City and $(B)$ Arkansas River at Portland on the Arkansas River, 1990-2010..

6. Seasonal streamflow hydrographs for Beaver Creek, Bear Creek, Brush Hollow, Fourmile Creek, and Hardscrabble Creek, Upper Arkansas River Basin, 2009-2010 .....24

7. Continuous specific conductance values at main-stem sites in the Upper Arkansas River Basin from Canon City to near Portland, 2009-2010

8. Comparison of median concentrations of six major ions in the Arkansas River, from Canon City to near Portland, 2009-2010...

9. Generalized geology and 2010 irrigated cropland in the Upper Arkansas River Basin, from Canon City to near Portland

10. Comparison of dissolved-solids in the Arkansas River and selected tributaries from Canon City to near Portland, 1990-2010.

11. Relation between dissolved-solids concentration and streamflow in the $(A)$ Arkansas River and $(B)$ selected tributaries from Canon City to near Portland, 2009-2010

12. Comparison of concentrations of dissolved nitrite-plus-nitrate and total phosphorus in the Arkansas River from Canon City to near Portland, 1990-2010 .32

13. Comparison of concentrations of dissolved selenium and dissolved uranium in the Arkansas River from Canon City to near Portland, 2009-2010.

14. Relation of concentrations of $(A)$ dissolved selenium and $(B)$ dissolved uranium with specific conductance and dissolved solids in the Arkansas River from Canon City to near Portland, 1990-2010.

15. Relation of concentrations of dissolved selenium and dissolved uranium with streamflow in the Arkansas River from Canon City to near Portland, 2009-2010 .35

16. Delta $D$ and delta ${ }^{18} 0$ in samples from the Arkansas River and selected tributaries from Canon City to near Portland, 2009-2010.

17. Streamflow hydrographs in the Arkansas River: $(A)$ Arkansas River near Avondale and Arkansas River near Nepsta, $(B)$ Arkansas River at Catlin Dam and Arkansas River near Rocky Ford, (C) Arkansas River at La Junta and Arkansas River at Las Animas, 1990-2010

18. Annual streamflow hydrographs $(A)$ for Huerfano River, Timpas Creek, and Crooked Arroyo and seasonal hyrdrographs $(B)$ for Sixmile Creek, Chicosa Creek, Apishipa River, Patterson Hollow, and Hungerford Hollow, 2009-2010

19. Continuous specific conductance values at main-stem sites in the Arkansas River Basin from Avondale to Las Animas, 2009-2010

20. Generalized geology and 2010 irrigated cropland in the Lower Arkansas River Basin, from Avondale to Las Animas.

21. Comparison of median concentrations of six major ions in the Arkansas River, from Avondale to Las Animas, 2009-2010. 
22. Comparison of dissolved-solids concentrations in the Arkansas River and

selected tributaries from Avondale to Las Animas, 1990-2010. . .46

23. Concentrations of dissolved solids and streamflow in the Arkansas River $(A)$ and selected tributaries $(B)$ from Avondale to Las Animas, 2009-2010 . .48

24. Comparison of concentrations of $(A)$ nitrite-plus-nitrate and $(B)$ total phosphorus in the Arkansas River from Avondale to Las Animas, 1990-2010 . .49

25. Comparison of concentrations of $(A)$ dissolved selenium and $(B)$ dissolved uranium in the Arkansas River from Avondale to Las Animas, 2009-2010

26. Relation of concentrations of $(A)$ dissolved selenium and $(B)$ dissolved uranium with specific conductance and dissolved solids in the Arkansas River from Avondale to Las Animas, 1990-2010.

27. Relation of concentrations of dissolved selenium and dissolved uranium with streamflow in the Arkansas River from Avondale to Las Animas, 2009-2010 .51

28. Delta $D$ and delta ${ }^{18} 0$ in samples from $(A)$ main-stem sites on the Arkansas River from Avondale to Las Animas and (B) selected tributaries, 2009-2010.

\section{Tables}

1. Site names, station names, information, and monitoring equipment information for sites in and near the Upper Arkansas River Basin and Lower Arkansas River Basin study areas, 2009-2010.

2. Analytical methods for analyses of water-quality samples collected in the Arkansas River Basin study areas, 2009-2010.

3. Periodic water-quality sampling sites in the Upper Arkansas River Basin and Lower Arkansas River Basin study areas, 2009-2010

4. Synoptic water-quality sampling sites in the Upper Arkansas River Basin and Lower Arkansas River Basin study areas, 2009-2010

5. Results of field blank quality-assurance samples collected in the Arkansas River Basin study areas, 2009-2010.

6. Relative percent difference between replicate quality-assurance samples collected in the Arkansas River Basin study areas, 2009-2010

7. Relative percent differences in concentration of dissolved selenium and specific conductance between EWI and point samples collected in the Arkansas River Basin study areas, 2009-2010.

8. Summary statistics for Arkansas River streamflow data 1990-2008 and 2009-2010 for Arkansas River at Canon City and Arkansas River at Portland gage stations ...........25

9. Regression equations relating dissolved-solids concentration and specific conductance in the Upper Arkansas River and selected tributaries from Canon City to near Portland, 2009-2010

10. Measured and calculated ungaged streamflow, contributions to dissolved-solids loads and dissolved-solids concentration for three reaches in the Upper Arkansas River Basin, September 15, 2010

11. Change in streamflow and loads of dissolved solids, selenium and uranium between main-stem sites in the Upper Arkansas River Basin, September 15, 2010

12. Summary statistics for Arkansas River streamflow data 1990-2008 and 2009-2010 for Arkansas River at Avondale, Arkansas River near Nepesta, Arkansas River at Catlin Dam, Arkansas River near Rocky Ford, Arkansas River at La Junta, and Arkansas River at Las Animas gage stations. 
13. Regression equations relating dissolved solids and specific conductance in the Lower Arkansas River and selected tributaries from Avondale to Las Animas, 2009-2010

14. Measured and calculated ungaged streamflow, contributions to dissolved-solids loads and dissolved-solids concentrations for six reaches in the Lower Arkansas River Basin, November 16-19, 2009.

15. Change in streamflow and loads of dissolved solids, selenium, and uranium between main-stem sites in the Lower Arkansas River Basin, November 16-19, 2009... 


\section{Conversion Factors}

Inch/Pound to SI

\begin{tabular}{|c|c|c|}
\hline Multiply & By & To obtain \\
\hline \multicolumn{3}{|c|}{ Length } \\
\hline inch (in.) & 2.54 & centimeter $(\mathrm{cm})$ \\
\hline inch (in.) & 25.4 & millimeter $(\mathrm{mm})$ \\
\hline foot $(\mathrm{ft})$ & 0.3048 & meter $(\mathrm{m})$ \\
\hline mile (mi) & 1.609 & kilometer $(\mathrm{km})$ \\
\hline yard $(\mathrm{yd})$ & 0.9144 & meter $(\mathrm{m})$ \\
\hline \multicolumn{3}{|c|}{ Area } \\
\hline acre & 4,047 & square meter $\left(\mathrm{m}^{2}\right)$ \\
\hline acre & 0.004047 & square kilometer $\left(\mathrm{km}^{2}\right)$ \\
\hline square mile $\left(\mathrm{mi}^{2}\right)$ & 259.0 & hectare (ha) \\
\hline square mile $\left(\mathrm{mi}^{2}\right)$ & 2.590 & square kilometer $\left(\mathrm{km}^{2}\right)$ \\
\hline \multicolumn{3}{|c|}{ Volume } \\
\hline gallon (gal) & 3.785 & liter $(\mathrm{L})$ \\
\hline gallon (gal) & 0.003785 & cubic meter $\left(\mathrm{m}^{3}\right)$ \\
\hline gallon (gal) & 3.785 & cubic decimeter $\left(\mathrm{dm}^{3}\right)$ \\
\hline million gallons (Mgal) & 3,785 & cubic meter $\left(\mathrm{m}^{3}\right)$ \\
\hline cubic inch $\left(\mathrm{in}^{3}\right)$ & 16.39 & cubic centimeter $\left(\mathrm{cm}^{3}\right)$ \\
\hline cubic inch $\left(\mathrm{in}^{3}\right)$ & 0.01639 & liter $(\mathrm{L})$ \\
\hline cubic foot $\left(\mathrm{ft}^{3}\right)$ & 0.02832 & cubic meter $\left(\mathrm{m}^{3}\right)$ \\
\hline acre-foot (acre-ft) & 1,233 & cubic meter $\left(\mathrm{m}^{3}\right)$ \\
\hline acre-foot (acre-ft) & 0.001233 & cubic hectometer $\left(\mathrm{hm}^{3}\right)$ \\
\hline \multicolumn{3}{|c|}{ Flow rate } \\
\hline acre-foot per day (acre-ft/d) & 0.01427 & cubic meter per second $\left(\mathrm{m}^{3} / \mathrm{s}\right)$ \\
\hline cubic foot per second $\left(\mathrm{ft}^{3} / \mathrm{s}\right)$ & 0.02832 & cubic meter per second $\left(\mathrm{m}^{3} / \mathrm{s}\right)$ \\
\hline million gallons per day (Mgal/d) & 0.04381 & cubic meter per second $\left(\mathrm{m}^{3} / \mathrm{s}\right)$ \\
\hline \multicolumn{3}{|c|}{ Mass } \\
\hline ton per day (ton/d) & 0.9072 & metric ton per day \\
\hline ton per day (ton/d) & 0.9072 & megagram per day $(\mathrm{Mg} / \mathrm{d})$ \\
\hline pound per day $(\mathrm{lb} / \mathrm{d})$ & 0.4536 & kilogram per day $(\mathrm{k} / \mathrm{d})$ \\
\hline
\end{tabular}

Temperature in degrees Celsius $\left({ }^{\circ} \mathrm{C}\right)$ may be converted to degrees Fahrenheit $\left({ }^{\circ} \mathrm{F}\right)$ as follows: ${ }^{\circ} \mathrm{F}=\left(1.8 x^{\circ} \mathrm{C}\right)+32$

Temperature in degrees Fahrenheit $\left({ }^{\circ} \mathrm{F}\right)$ may be converted to degrees Celsius $\left({ }^{\circ} \mathrm{C}\right)$ as follows: ${ }^{\circ} \mathrm{C}=\left({ }^{\circ} \mathrm{F}-32\right) / 1.8$

Vertical coordinate information is referenced to the North American Vertical Datum of 1988 (NAVD 88).

Horizontal coordinate information is referenced to the North American Datum of 1983 (NAD 83).

Specific conductance is given in microsiemens per centimeter at 25 degrees Celsius $(\mu \mathrm{S} / \mathrm{cm}$ at $\left.25^{\circ} \mathrm{C}\right)$.

Concentrations of chemical constituents in water are given either in milligrams per liter (mg/L) or micrograms per liter $(\mu \mathrm{g} / \mathrm{L})$. 


\title{
Acronyms Used in this Report
}

\author{
DS Dissolved solids \\ DWR Division of Water Resources \\ USGS U.S. Geological Survey \\ RRPG Regional Resource Planning Group \\ NWIS National Water Information System \\ SC Specific conductance \\ USEPA U.S. Environmental Protection Agency \\ UARB Upper Arkansas River Basin \\ LARB Lower Arkansas River Basin \\ NWOL National Water Quality Laboratory
}




\title{
Characterization of Streamflow, Water Quality, and Instantaneous Dissolved Solids, Selenium, and Uranium Loads in Selected Reaches of the Arkansas River, Southeastern Colorado, 2009-2010
}

\author{
By Tamara Ivahnenko, Roderick F. Ortiz, and Robert W. Stogner, Sr.
}

\section{Abstract}

As a result of continued water-quality concerns in the Arkansas River, including metal contamination from historical mining practices, potential effects associated with storage and movement of water, point- and nonpoint-source contamination, population growth, storm-water flows, and future changes in land and water use, the Arkansas River Basin Regional Resource Planning Group (RRPG) developed a strategy to address these issues. As such, a cooperative strategic approach to address the multiple water-quality concerns within selected reaches of the Arkansas River was developed to (1) identify stream reaches where stream-aquifer interactions have a pronounced effect on water quality and (or) where reactive transport, and physical and (or) chemical alteration of flow during conveyance, is occurring, (2) quantify loading from point sources, and (3) determine source areas and mass loading for selected constituents.

To date in the Arkansas River Basin, most existing water-quality data have been collected for the purposes of characterizing current water-quality conditions for selected river reaches as they pertain to in-stream classifications and standards or had not been collected in a manner that allows for rigorous and accurate analysis of mass loading. Poor understanding of streamflow from ungaged tributary and return flows frequently result in poorly defined water budgets that are the basis for determining source contributions. The purpose of this report is to characterize streamflow and water-quality data collected along the selected reaches of the Arkansas River from Canon City to near Portland (Upper Arkansas River Basin (UARB)) and from Avondale to Las Animas (Lower Arkansas River Basin (LARB)) during 2009 and 2010, identify critical stream reaches where stream-aquifer interactions may potentially have a pronounced effect on water quality (or where point-source discharges are a significant load to the stream), and to identify potential load source areas for selected constituents within the UARB and LARB study reaches.

Data-collection activities were conducted for 2 years in the UARB and LARB. Water-quality samples were collected from June through December 2009 and from May through
October 2010. In each study area, samples were collected periodically to characterize the water quality throughout the various hydrologic conditions observed in the Arkansas River Basin. Additionally, a limited number of synoptic (time-oftravel) sampling events were conducted to provide a better understanding of the in-stream water-quality processes using mass-loading analyses.

Main-stem dissolved solids (DS) (salinity) median concentrations increase downstream in the Arkansas River from Canon City (153 milligram per liter $(\mathrm{mg} / \mathrm{L}))$ to near Portland $(264 \mathrm{mg} / \mathrm{L})$. In addition to irrigation return flows, inflows from groundwater may contribute to the high DS concentrations in the tributaries, especially those tributaries below Florence, Colorado, and those that drain the Penrose, Colorado, area where hay, pasture, orchard, and cropland acres are irrigated. Additionally, the higher DS concentrations downstream from Florence can be attributed to differences in geology and variation in the chemical composition of the bedrock.

Concentrations of dissolved selenium and dissolved uranium increase in water samples downstream from Canon City to near Portland. One concentration of selenium in a sample from Bear Creek and concentrations of uranium in samples from Bear, Hardscrabble, and Ranger Creeks, and Brush Hollow equaled or exceeded U.S. Environmental Protection Agency (USEPA) drinking-water standards (50 and $30 \mu \mathrm{g} / \mathrm{L}$, respectively) for those elements.

There were statistical differences between the DS loads in the Arkansas River during low- streamflow conditions in 2009-2010. Using the Tukey's test for multiple comparisons to determine which sites were different from each other resulted in showing statistically significant differences between instantaneous DS loads for sites Arkansas River at Canon City to Arkansas River at Portland. The same sites were significant for selenium loads. The river section from Arkansas River at Canon City to Arkansas River at Portland is a potential source area of dissolved solids and selenium to the UARB. No statistically significant difference between sites was determined for uranium loads.

To estimate the amount of ungaged contribution to DS loads from ungaged flows and other sources, the water balance 
for the synoptic sampling event on September 15, 2010, was used as the basis for calculating the concentration of DS from the ungaged sources. Calculated DS concentrations from ungaged sources for the UARB were Arkansas River at Canon City to Arkansas River near Canon City, $500.4 \mathrm{mg} / \mathrm{L}$; Arkansas River near Canon City to Arkansas River at Portland, $706.8 \mathrm{mg} / \mathrm{L}$; and Arkansas River at Portland to Arkansas River near Portland, $191 \mathrm{mg} / \mathrm{L}$. The calculated DS concentrations for each of the reaches in the UARB fall within the reported range of groundwater DS concentrations, and groundwater is a plausible source for the ungaged contribution to the DS load. In addition to groundwater, ungaged irrigation return flow and tributaries may also be sources of the DS load; however, proportions of contributions from these sources are unknown. The ungaged contributions to DS load, ungaged streamflow, and calculated DS concentration are only for the synoptic samples collected in September 2010, and may likely vary throughout the year for different streamflow and water-quality conditions.

The LARB main-stem DS median concentrations increase downstream from Avondale $(557 \mathrm{mg} / \mathrm{L})$ to Las Animas $(1,725 \mathrm{mg} / \mathrm{L})$. Median DS concentrations in tributaries and the La Junta wastewater treatment plant (WWTP) range from $1,050 \mathrm{mg} / \mathrm{L}$ in Hungerford Hollow to $2,770 \mathrm{mg} / \mathrm{L}$ in water sampled from the Huerfano River. As in the UARB, irrigation return flows and inflows from groundwater likely contribute to the high DS concentrations in all the tributaries, whereas differences in DS concentration ranges between the selected tributaries can be attributed to differences in geology and the chemical composition of the bedrock.

Median dissolved selenium concentrations vary in the main-stem sites and ranged from 8.4 to $12.2 \mu \mathrm{g} / \mathrm{L}$ in Arkansas River near Avondale to Arkansas River at Las Animas, and selenium concentrations increase downstream at sites from Arkansas River near Nepesta to Arkansas River at La Junta. Median selenium concentrations measured in tributaries generally were higher than those in the main-stem sites; however, no concentrations of selenium in any of the sampled sites exceeded USEPA primary drinking-water standards. The median dissolved uranium concentration $(39 \mu \mathrm{g} / \mathrm{L})$ in Sixmile Creek exceeded the USEPA drinking-water standard. The tributaries, Sixmile Creek, IR-43, Huerfano River, and Chicosa Creek all drain the lower part of the Cretaceous-age Pierre Shale and upper part of the Niobrara Formation, which are suspected geologic sources of uranium. Patterson Hollow had two samples that exceeded the drinking-water standard, one collected in November 2009 and the other in June 2010. Timpas Creek and Crooked Arroyo, each had one sample that exceeded the drinking-water standard. Patterson Hollow, Timpas Creek, and Crooked Arroyo basins are underlain by the upper part of the Niobrara Formation. The samples with exceedences were collected in the fall, when flows in these tributaries were low.

The tributary samples and samples from the La Junta WWTP plot below the GMWL and the Colorado LMWL, indicating that all samples are enriched in $\delta \mathrm{D}$ and $\mathrm{d}^{18} \mathrm{O}$, probably as a result of evaporation. A line calculated for the tributary samples is similar to the main stem (slope of 6.16). Samples from Sixmile Creek, IR-43, Huerfano River, Crooked Arroyo, and La Junta WWTP group with little or no temporal variation (within 1 per mil unit) in the isotope concentrations, suggesting the source water for these tributaries does not undergo evaporation through irrigation return and reuse. The remaining sampled tributaries have greater temporal variation in isotopic ratios suggesting multiple evaporation cycles or, as for the main-stem sites, possibly increasing contribution of groundwater that has been affected by evaporation and irrigation recharge. However, as in the UARB, no LARB groundwater isotope samples are available for comparison to the surfacewater samples.

A Kruskall-Wallis and Tukey's test on periodic and synoptic DS loads in 2009-2010, indicated statistically significant differences between DS loads at the main-stem sites. The significant differences between instantaneous DS loads at the main-stem sites were from Arkansas River near Rocky Ford to Arkansas River at La Junta. Further investigation would be needed to evaluate potential dissolved-solids source areas within the Arkansas River from Arkansas River near Rocky Ford to Arkansas River at La Junta. A Kruskall-Wallis test on selenium loads from samples collected during low-flow periods for this study from 2009-2010 indicated statistically significant differences between loads at the main-stem sites. Using the Tukey's test for multiple comparisons, the differences between the sites were statistically significant for Arkansas near Nepesta to Arkansas River at La Junta. The same statistical test for uranium loads in the LARB indicated the differences between the sites are significant, as with selenium, for Arkansas near Nepesta to Arkansas River at La Junta. Further investigation would be needed to describe the source or sources in these reaches in greater detail.

To estimate the amount of ungaged contribution to DS loads from ungaged flows and other sources in the LARB, the water balance for the synoptic on November 16-19, 2009 was used as the basis for calculating the concentration of DS from the ungaged sources. Calculated DS concentrations from ungaged sources for the LARB were Arkansas River near Avondale to Arkansas River near Nepesta, 1,069 mg/L; Arkansas River near Nepesta to Arkansas River at Catlin Dam, 89.6 mg/L; Arkansas River at Catlin Dam to Arkansas River near Rocky Ford, not calculated; Arkansas River near Rocky Ford to Arkansas River at Swink, 4,926 mg/L; Arkansas River at Swink to Arkansas River at La Junta, $843 \mathrm{mg} / \mathrm{L}$; and Arkansas River at La Junta to Arkansas River at Las Animas, 1,725 $\mathrm{mg} / \mathrm{L}$. The DS concentrations of ungaged sources for each of the reaches in the LARB fall within the reported range of groundwater DS concentrations, and groundwater is a plausible source for the estimated DS load. In addition to groundwater, ungaged irrigation return flow and tributaries may also be sources of the DS load; however, proportions of contributions, as in the UARB, from these sources are unknown. The ungaged streamflow, ungaged contributions to DS load, and calculated DS concentration for an assumed ungaged single source for all six reaches in the LARB are applicable only for 
November 16-19, 2009, and may likely vary throughout the year for different streamflow and water-quality conditions.

\section{Introduction}

Water within the Arkansas River Basin in Colorado is used for a wide variety of purposes including agricultural, municipal, recreational, power production, industrial, livestock, domestic, and mining. In 2009, more than 85 percent of the water delivered in the Arkansas River Basin was for irrigation or storage (Colorado Division of Water Resources, 2010). Although municipal and industrial uses accounted for only 12 percent of the total water deliveries in 2009 (Colorado Division of Water Resources, 2010), population growth in the basin will likely drive changes in water storage, water releases, and (or) transfer of water within or outside of the Arkansas River Basin. As such, numerous entities have expressed concerns about a wide range of water-quality issues in the Arkansas River Basin in Colorado.

In the Arkansas River Basin upstream from Pueblo Reservoir (fig. 1), water-quality concerns generally are associated with metal contamination from historical mining practices, fish and biological integrity issues, increased salt loading, and concerns about potential effects associated with storage and movement of water. Downstream from Pueblo Reservoir, water-quality concerns are associated with a wide variety of environmental stressors including point- and nonpoint-source contamination, population growth, storm-water flows, and future changes in land and water use.

As a result of continued water-quality concerns, the Arkansas River Basin Regional Resource Planning Group (RRPG), developed a strategy to address multiple water-quality concerns in the Arkansas River Basin. Currently (2011), the Arkansas River Basin RRPG entities include the City of Aurora, Colorado Springs Utilities, Lower Arkansas Valley Water Conservancy District, Pueblo Board of Water Works, Southeastern Colorado Water Conservancy District, and the Upper Arkansas Water Conservancy District. The goals of the strategy include (1) synthesizing electronically available data and studies that could be integrated to help provide a basinwide understanding of water-quality conditions, (2) summarizing and characterizing available water-quality data to address concerns identified and prioritized by stakeholders, and (3) identifying gaps in existing data. The U.S. Geological Survey (USGS) is working in cooperation with the Arkansas River Basin RRPG to help address these goals.

To provide an electronically available data set, the USGS developed, and is maintaining, a water-quality data repository for selected study areas in Colorado including the Arkansas River Basin. This repository combines water-quality data from the USGS National Water Information System (NWIS) and the U.S. Environmental Protection Agency (USEPA) STORET databases and represents data from Federal, State, academia, and local sources. The interactive data repository for the
Arkansas River Basin (U.S. Geological Survey, 2009) can be accessed at $h t t p: / / r m g s c . c r . u s g s . g o v / c w q d r / A r k a n s a s / i n d e x$. shtml.

The occurrence of high concentrations of dissolved solids (DS), selenium, and uranium in groundwater and surface water affecting agricultural productivity, in-stream water quality, and (or) drinking-water quality in selected parts of the basin was identified as a priority water-quality concern by stakeholders (Miller and others, 2010). In 2007, the USGS, in cooperation with the Arkansas River Basin RRPG, began a retrospective evaluation of available data to characterize the occurrence and distribution of dissolved solids, selenium, and uranium in groundwater and surface water from the headwaters of the Arkansas River to Coolidge, Kansas (Miller and others, 2010).

Numerous data gaps were identified in the existing data for the Arkansas River Basin. In general, streamflow has been and is being monitored in the Arkansas River near the mouths of major tributaries and in the major canals. However, minor tributary streamflow and irrigation return flow typically are not monitored, although the data are needed for accurately determining water budgets and other hydrologic aspects. Existing water-quality data generally were collected to characterize water-quality conditions for selected river reaches as they pertain to in-stream classifications and standards. These data were primarily periodic samples only and are not necessarily applicable to rigorous and accurate analysis of mass loading and determining source contributions. Data needed to assess the dominant physical, chemical, or biological processes that created the existing water-quality conditions are generally unavailable.

In order to address the gaps in data, a cooperative strategic approach was developed to (1) identify stream reaches where stream-aquifer interactions have a pronounced effect on water quality and (or) where reactive transport, and physical and (or) chemical alteration of flow during conveyance is occurring, (2) quantify loading from point sources, and (3) determine source areas and mass loading for selected constituents. In 2009, the USGS in cooperation with the entities of the Arkansas River Basin RRPG, began a study to help address some of the gaps in data and provide hydrologic information needed to characterize streamflow, water quality, and instantaneous dissolved-solids, selenium, and uranium loads for selected reaches of the Arkansas River.

\section{Purpose and Scope}

The purpose of this report is to describe the characteristics of streamflow, water quality, and instantaneous dissolvedsolids, selenium, and uranium loads in selected reaches of the Arkansas River Basin in southeastern Colorado, identify critical Arkansas River reaches where stream-aquifer interactions may potentially have a pronounced effect on water quality (or where point-source discharges are a significant load to the stream), and to identify potential load source areas for selected constituents within the study reaches. The first 


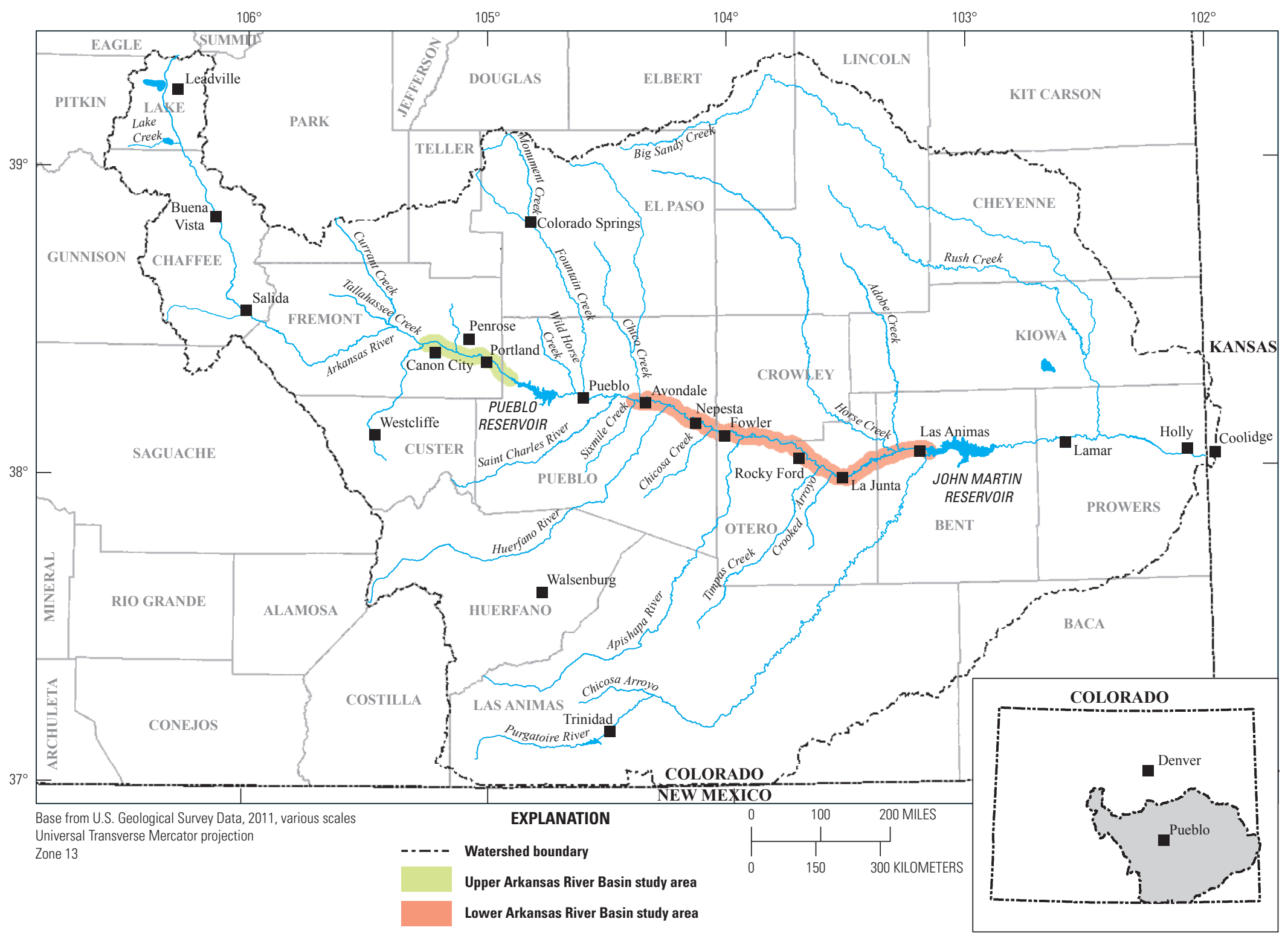

Figure 1. Location of the Arkansas River Basin in Colorado. 
main study-area reach includes the Arkansas River, tributaries, and diversions from Canon City to near the upstream end of Pueblo Reservoir and is designated in this report as the Upper Arkansas River Basin (UARB) reach (fig. 2). The second main study-area reach is downstream from Pueblo Reservoir and includes the Arkansas River, tributaries, and diversions from Avondale to Las Animas and is designated in this report as the Lower Arkansas River Basin (LARB) reach (fig. 3).

Existing data and data collected specifically for this study were used. Numerous study-specific temporary streamflowgaging stations were installed and operated during 2009-2010 along the Arkansas River and its tributaries to augment the existing streamflow-gaging network in the study area. Several continuous water-temperature and specific-conductance monitors were installed and operated seasonally along the Arkansas River. Periodic water-quality sampling was conducted from June through December 2009 and from May through October 2010 at numerous main-stem, tributary, and diversion sites. Existing water-quality data also were used, although data for pre-1990 samples were not included because field-sampling protocols and laboratory analysis procedures for trace elements and radionuclides were not directly comparable to 1990-2010 field protocols and laboratory procedures. Synoptic sampling using Lagrangian (time-of-travel) sampling designs were conducted during various streamflow conditions in both main reaches during 2009-2010 to provide a better understanding of the in-stream water-quality processes using mass-loading analyses. Statistical methods were used to determine significant differences between sites for various characteristics. Mass-balance methods were used to help determine ungaged streamflow and ungaged contributions to dissolved solids loads between sites in the two main reaches.

\section{Description of the Study Area}

The Arkansas River originates among some of the highest peaks in the continental United States, flowing from the high mountain basins onto the plains of southeastern Colorado. Upstream from Canon City, the Arkansas River is characterized by a steep gradient and high-velocity flows that are confined to a relatively narrow rock and cobble stream channel (Miller and others, 2010). Downstream from Canon City, the river gradient decreases as the river flows generally eastward out of the mountains onto the plains. Pueblo Reservoir is the first main-stem reservoir on the Arkansas River (fig. 1) and is used to control the release of stored water to the predominantly agricultural river valley downstream from Pueblo. Water is stored in Pueblo Reservoir for a variety of reasons, including flood control, irrigation, and public water supply. Fountain Creek is a major tributary in the basin and flows into the Arkansas River within the city limits of Pueblo (fig. 1). Downstream from Fountain Creek, the river channel is a shifting sand channel that meanders along the alluvial flood plain (Miller and others, 2010). For nearly 120 miles downstream from Pueblo Reservoir, water from the river is diverted through a network of irrigation canals and is applied and reapplied to grow crops in the valley. Near Las Animas, the river flows into John Martin Reservoir which is used to regulate the streamflow for downstream uses. Storage decreases substantially in both reservoirs by the end of the growing season because of decreased inflow and large releases to meet downstream demands for irrigation water (Lewis and Brendle, 1998).

Streamflow in the Arkansas River exhibits considerable seasonal variability (fig. 4). The majority of the total annual streamflow results from snowmelt runoff in the mountains at the western boundary of the basin, including water native to the watershed and water brought into the watershed by transmountain diversions (Bureau of Reclamation, 2012). Streamflow generally is at an annual minimum from October through March and is maintained by natural base flow and reservoir releases. Starting in April, streamflow begins to increase as snow begins to melt leading to maximum streamflow during May and June. During July through September, streamflow in the Arkansas River includes decreasing amounts of snowmelt and is augmented by releases of stored water. During this time, streamflow can increase substantially over short periods following intense rainstorms and subsequent runoff from tributaries. During July through September, most streamflow in the plains is diverted for irrigation uses.

\section{Previous Investigations}

Streamflow and water quality in the Arkansas River Basin have been analyzed previously by numerous investigators. In 1993, a comprehensive 3-year water-quality datacollection program was completed in the Arkansas River Basin in Colorado (Dash and Ortiz, 1996). An assessment of the surface-water quality in the basin was done using these data and included analysis of dissolved solids (DS), major ions, trace elements, nutrients, radio-chemical constituents, pesticides, suspended sediment, and bacteria (Ortiz and others, 1998). Gaydos (1980), Abbott (1985), Cain (1985; 1987), and Mueller and others (1991) described the quality of the Arkansas River including water quality of irrigation-return flows, relations to specific conductance (SC), and operation of water systems. Miles (1977) focused on the downstream increase in salinity in the Arkansas River. Cain and Edelmann (1980) and Cain and others (1980) investigated the effects of municipal and industrial wastewater discharges to the Arkansas River near Pueblo. Miller and others (2010) investigated the occurrence and distribution of dissolved solids, selenium, and uranium in the Arkansas River Basin, based on retrospective data. Summaries of previous investigations, including those listed here, are provided in Miller and others (2010). Various publications documenting ongoing research by Colorado State University in the Lower Arkansas River Basin are available (Colorado State University, 2009). These studies provided historical water-quality information for and assisted in developing the scope of this study. 


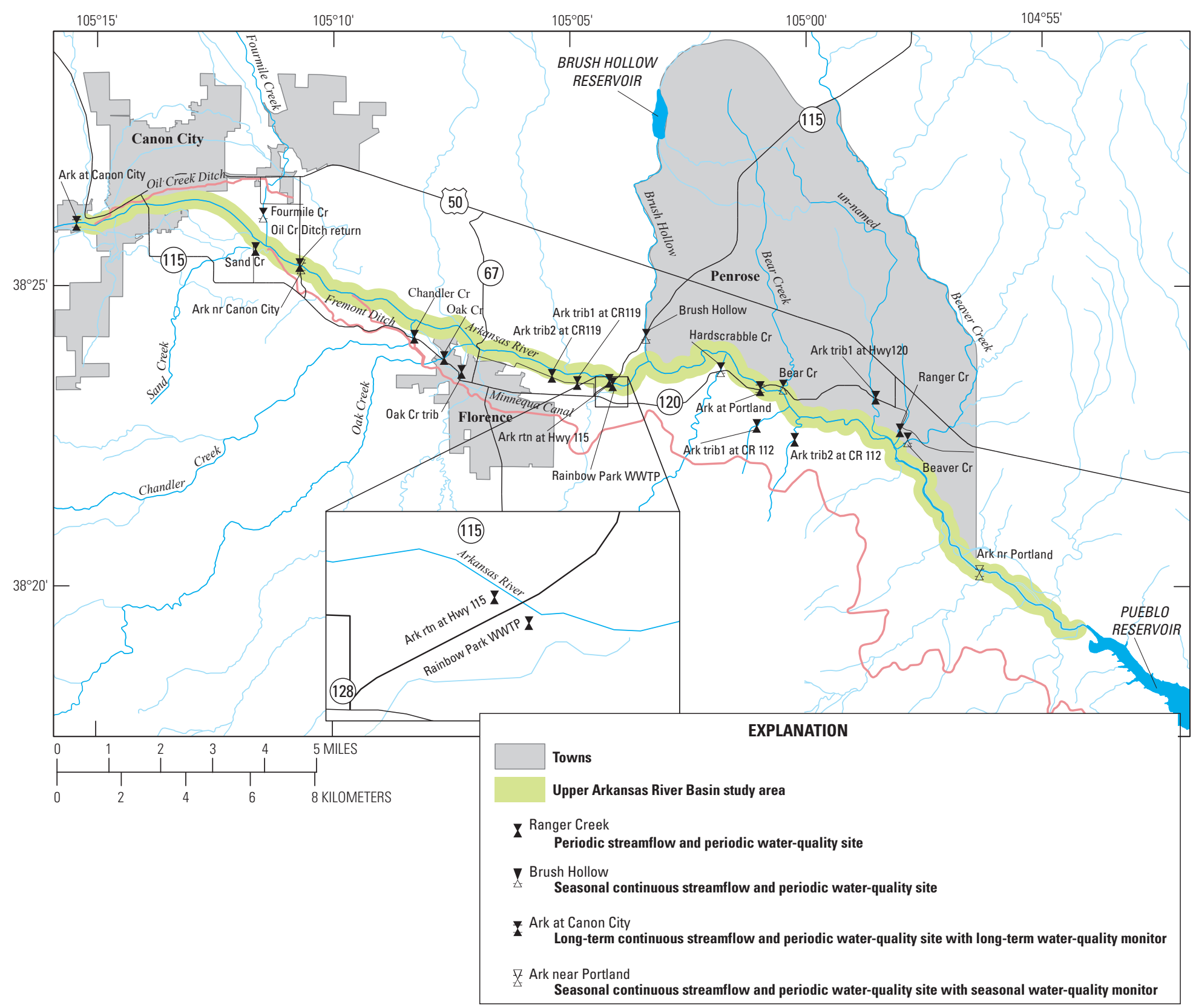

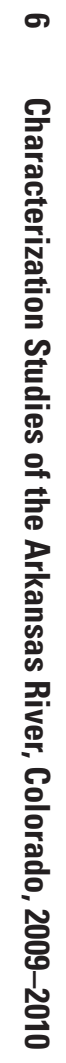

Figure 2. Delineation of the Upper Arkansas River Basin study area and locations of streamflow and water-quality sites, Canon City to Pueblo Reservoir, Colorado. 


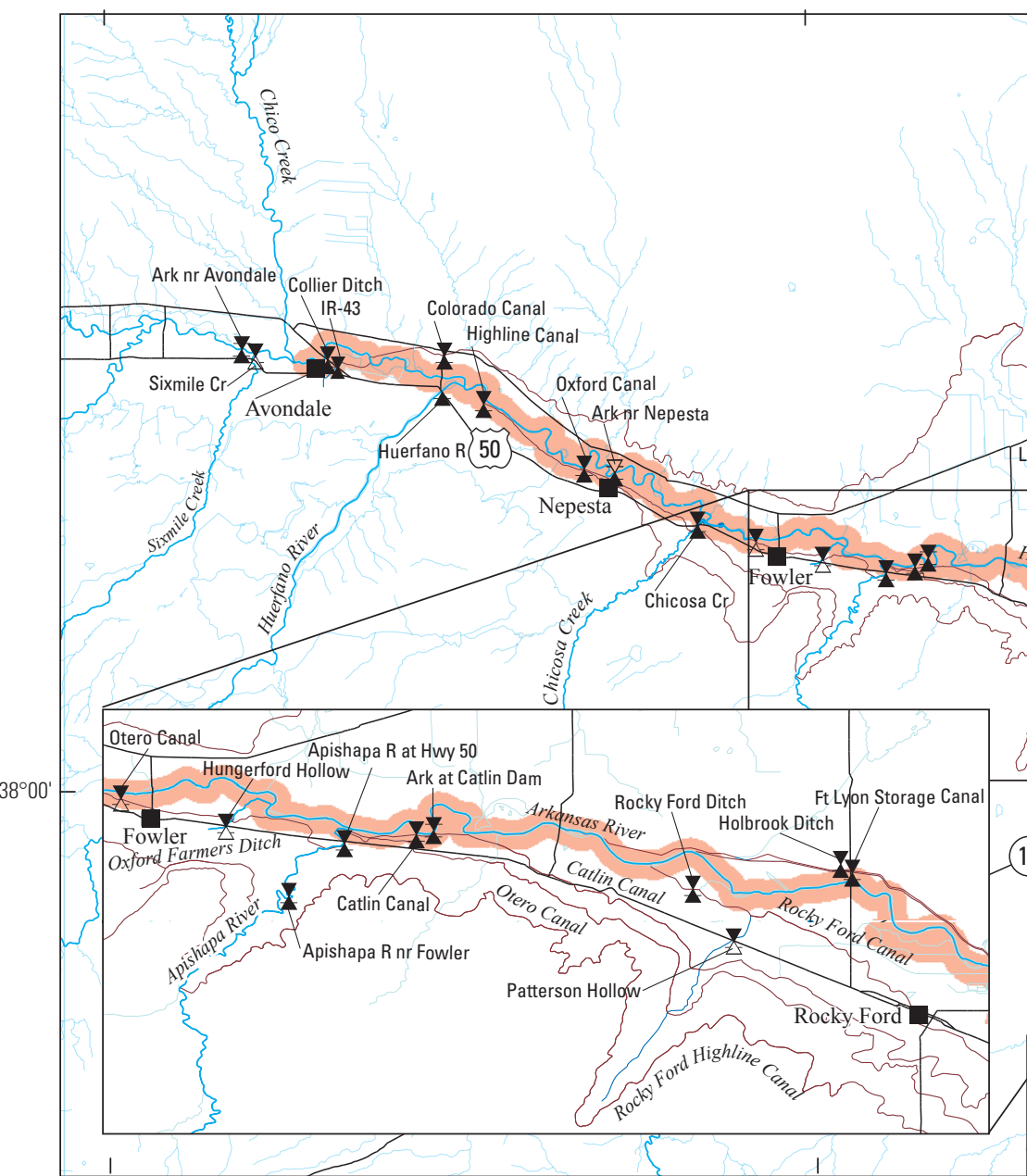

Base from U.S. Geological Survey Data, 2011, various scales Universal Transverse Mercator projection Zone 13

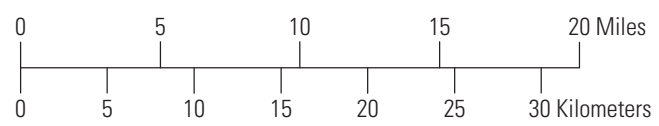

Figure 3. Delineation of the Lower Arkansas River Basin study area and location of streamflow and water-quality sites, Avondale to Las Animas, Colorado.
Z Ark at Las Animas

Seasonal continuous streamflow and periodic water-quality site with seasonal water-quality monitor 
$\boldsymbol{A}$

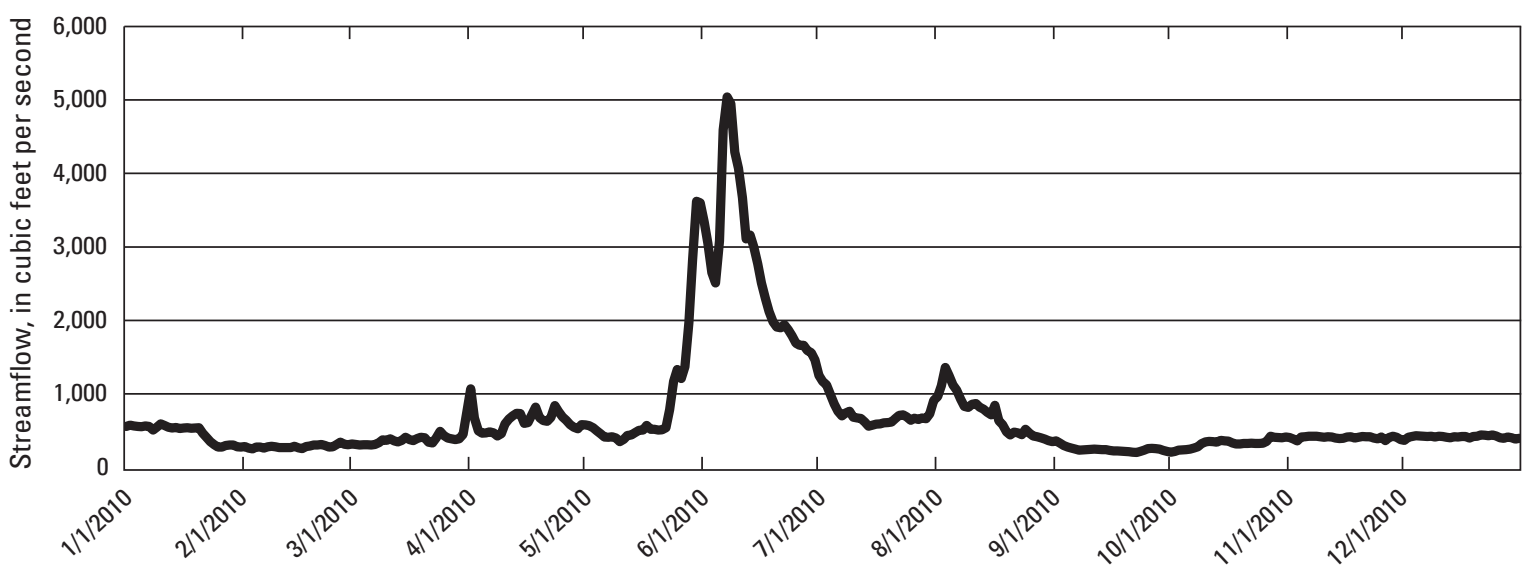

B

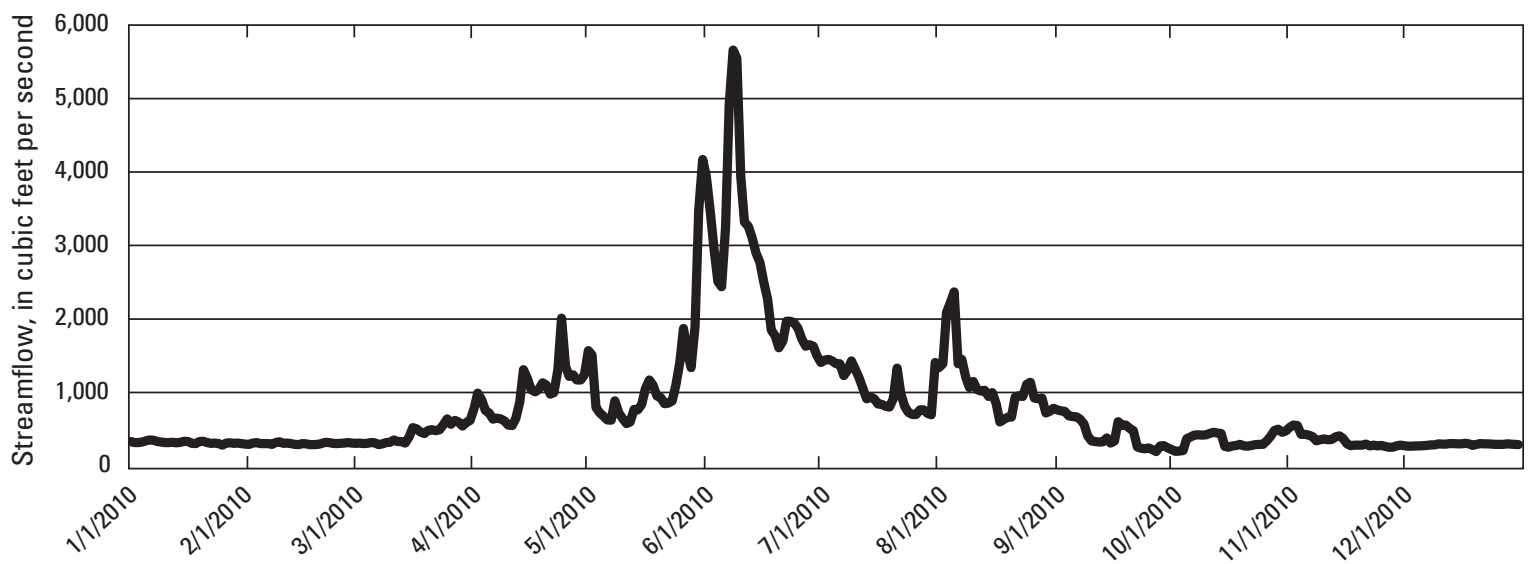

C

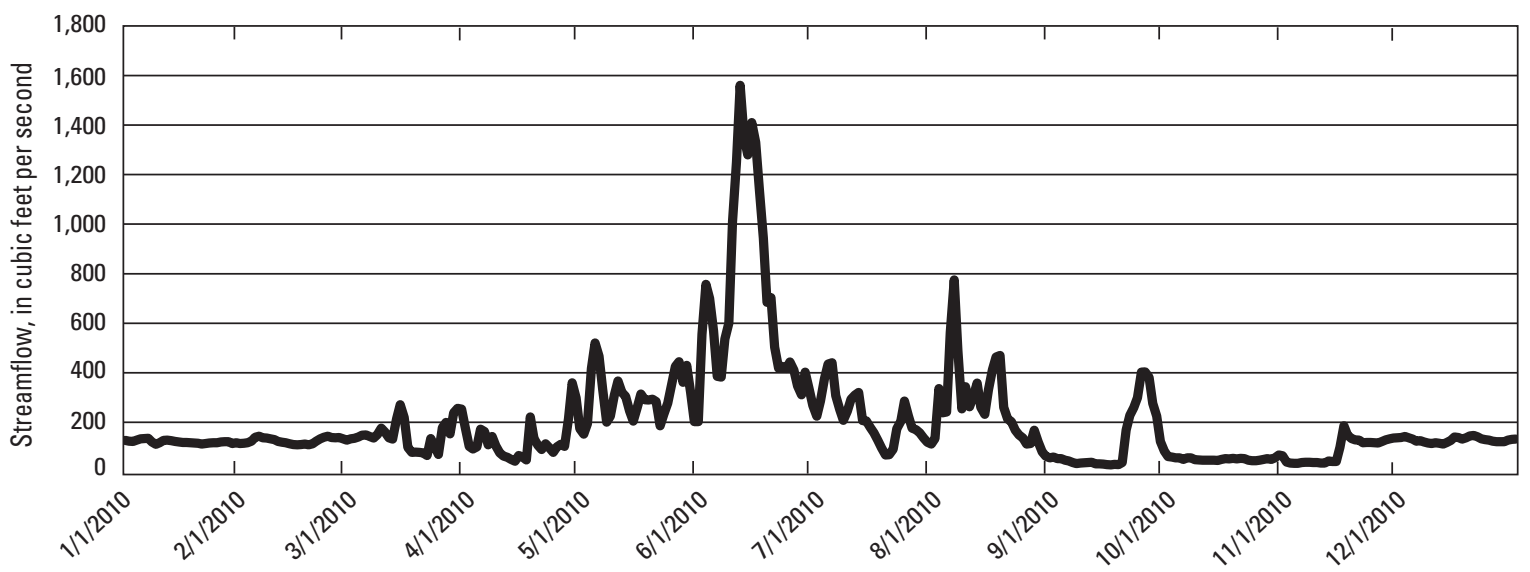

Figure 4. Annual Arkansas River hydrographs (2010) $(A)$ Arkansas at Portland, $(B)$ Arkansas near Avondale, and $(C)$ Arkansas at Las Animas. 


\section{Methods}

General information for sites in and near the UARB and LARB is listed in table 1. In this report, sites generally will be identified by the site name. The following section characterizes the types of available streamflow and water-quality data evaluated in this report. Quality-assurance procedures also are discussed.

\section{Available Streamflow Data}

Streamflow data analyzed for this report are of two general types: instantaneous or daily mean values. Instantaneous streamflow data can be either measured directly by volumetric or streamflow methods at study-specific temporary gaging stations or derived from developed stage/streamflow relations at long-term gaging stations. Appropriate USGS streamflow-measuring techniques, as defined by Rantz and others (1982a), were used to determine streamflow (including estimated streamflow) at the sampling sites. Where available, instantaneous streamflows were determined from long-term or study-specific temporary streamflow stations maintained by the USGS or from long-term streamflow stations maintained by the Colorado Division of Water Resources (CODWR). Computed daily mean streamflow values for long-term or study-specific temporary stations operated by either agency or for wastewater treatment facilities also were compiled for the analysis of daily mass loading.

\section{U.S. Geological Survey Streamflow Data}

No long-term streamflow measuring stations are operated by the USGS in the UARB study area. However, two study-specific temporary gaging stations on the main stem were operational during parts of the study period (table 1 and fig. 2). Pressure transducer equipment was installed at sites Ark nr Canon City and Ark nr Portland. Generally, daily mean streamflow values were computed for July through December 2009 and for May through November 2010. Suggested procedures for maintaining these records are described in Rantz and others $(1982 \mathrm{a}, \mathrm{b})$.

In addition, pressure transducers were installed and operated seasonally at five tributary stations in the UARB to aid in the quantification of inflows to the river during the study (table 1). Seasonal data were available for Fourmile Cr, Brush Hollow, Hardscrabble Cr, Bear Cr, and Beaver Cr. Generally, daily mean streamflow values were computed for a period of record similar to that of the two main-stem stations with the exceptions of Beaver Cr, which only was operational in 2009, and Brush Hollow, which only was operational in 2010.

Two long-term main-stem streamflow-gaging stations are operated by the USGS in the LARB study area (fig. 3). At least 20 years of streamflow data are available for Ark nr Avondale and Ark at Las Animas (U.S. Geological Survey, 2012). Unitvalue (15-minute record) and daily mean streamflow data were available from each of these two stations for the study period 2009-2010. One study-specific temporary gaging station on the main stem of the river-Ark at Swink — was operational during parts of the study period (table 1). Pressure transducer equipment was installed and operated at this site and, generally, daily mean streamflow values were computed for July through December 2009 and for May through November 2010. Procedures for maintaining these records are described in Rantz and others (1982a,b).

Two long-term streamflow stations on tributaries to the Arkansas River - the Huerfano R and Timpas Cr-are operated by the USGS (U.S. Geological Survey, 2012). Pressure transducers were installed and operated seasonally at six tributary stations in the LARB to aid in the quantification of inflows to the river during the study (table 1). Seasonal data were available for Sixmile $\mathrm{Cr}$, Chicosa $\mathrm{Cr}$, Hungerford Hollow, Apishapa R, Crooked Arroyo, and Anderson Arroyo. Generally, daily mean streamflow values were computed for a period of record similar to that of the main-stem station at Swink, with the exception of Anderson Arroyo, which was only operational in 2009.

\section{Colorado Division of Water Resources Streamflow Data}

In the UARB, the CODWR operates two streamflow measuring stations on the Arkansas River (fig. 3, table 1). At least 20 years of streamflow data are available for Ark at Canon City and Ark at Portland. Generally, daily mean streamflow values were available for all dates during the study period. Streamflow data for most stations managed by the State of Colorado can be accessed through the Colorado's Surface Water Conditions Web site at http://www.dwr.state.co.us/ SurfaceWater/default.aspx. One diversion site in the UARB, Minnequa Canal, was used to quantify diversion flows from the river during the study period (table 1).

The CODWR also maintains three streamflow measuring stations on the Arkansas River in the LARB (fig. 3, table 1). At least 20 years of streamflow data are available for Ark nr Nepesta, Ark nr Rocky Ford, and Ark at La Junta. Generally, daily mean streamflow values were available for all dates during the study period. Seasonal streamflow data are collected by the State at several diversion sites in the LARB. Seasonal data were available for Collier Ditch, Colorado Canal, Highline Canal, Oxford Canal, Otero Canal, Catlin Canal, Holbrook Ditch, Fort Lyon Storage Canal, Rocky Ford Ditch, and Fort Lyon Canal. Data from these 10 sites were used to quantify diversion of flows from the river during the study period (table 1). Generally, daily mean streamflow values were available for a period of record when water was being diverted at the headgates. 
Table 1. Site names, station names, information, and monitoring equipment information for sites in and near the Upper Arkansas River Basin and Lower Arkansas River Basin study areas, 2009-2010.

[USGS, U.S. Geological Survey; MS, main stem; TR, tributary; R, River; DV, diversion canal or ditch; WWTP, wastewater treatment plant; eQgs, existing USGS streamflow station; eQco, existing Colorado Division of Water Resources streamflow station; sQgs, seasonal USGS streamflow station; user; user supplied streamflow data; eQWgs; existing USGS water-quality station; sQWgs, seasonal USGS water-quality station; WWTP, wastewater treatment plant; CODWR; Colorado Division of Water Resources; --, no equipment]

\begin{tabular}{|c|c|c|c|c|}
\hline Site name & $\begin{array}{l}\text { USGS station identifi- } \\
\text { cation number }\end{array}$ & USGS station name & Site type & $\begin{array}{c}\text { Available } \\
\text { monitoring } \\
\text { equipment on site }\end{array}$ \\
\hline \multicolumn{5}{|c|}{ Upper Arkansas River Basin study reach: Canon City to Pueblo Reservoir (in downstream order) } \\
\hline Lake $\mathrm{Cr}^{1}$ & 07084500 & Lake Creek above Twin Lakes Reservoir & TR & eQgs \\
\hline Ark at Granite ${ }^{1}$ & 07086000 & Arkansas R at Granite & MS & eQgs \\
\hline Sand $\mathrm{Cr}$ & 382536105113901 & Sand Creek near mouth at Canon City & TR & -- \\
\hline Fourmile $\mathrm{Cr}$ & 07096500 & Fourmile Creek near Canon City & TR & sQgs \\
\hline Ark nr Canon City & 07096515 & Arkansas R at Fourmile Rd near Canon City & MS & sQgs, sQWgs \\
\hline Oil Cr Ditch return & 382520105104101 & $\begin{array}{l}\text { Oil Creek Ditch return flow at Fourmile Road near } \\
\text { Canon City }\end{array}$ & TR & -- \\
\hline Oak Cr & 382348105073901 & Oak Creek at Hwy 115 near Florence & TR & -- \\
\hline Oak Cr trib & 382334105071701 & Oak Creek tributary at Hwy 115 at Florence & TR & -- \\
\hline Ark trib 2 at CR 119 & 382330105052301 & Arkansas R trib 2 at CR 119 near Florence & TR & -- \\
\hline Ark trib 1 at CR 119 & 382323105045001 & Arkansas R trib 1 at CR 119 near Florence & TR & -- \\
\hline Ark rtn at Hwy 115 & 382324105040601 & Arkansas R return at Hwy 115 near Florence & TR & -- \\
\hline Rainbow Park WWTP & 382322105040501 & $\begin{array}{l}\text { Rainbow Park Regional WWTP effluent outfall } \\
\text { near Florence }\end{array}$ & WW & user \\
\hline Ark trib 2 at CR 112 & 382226105001501 & Arkansas R trib 2 at CR 112 near Portland & $\mathrm{TR}$ & -- \\
\hline Ark trib 1 at Hwy 120 & 382308104583201 & Arkansas R trib 1 at Hwy 120 near Portland & TR & -- \\
\hline Ranger $\mathrm{Cr}$ & 382236104580101 & Ranger Creek at Old Portland Hwy near Portland & TR & -- \\
\hline Beaver $\mathrm{Cr}$ & 07099100 & Beaver Creek near Portland & TR & $\mathrm{sQgs}^{3}$ \\
\hline Ark nr Portland & 07099200 & Arkansas R near Portland & MS & sQgs, sQWgs \\
\hline \multicolumn{5}{|c|}{ Lower Arkansas River Basin study reach: Avondale to Las Animas (in downstream order) } \\
\hline Ark nr Avondale ${ }^{5}$ & 07109500 & Arkansas R near Avondale & MS & eQgs, eQWgs \\
\hline Sixmile $\mathrm{Cr}$ & 381440104234401 & Sixmile Creek trib abv Hwy 50 near Avondale & TR & sQgs \\
\hline Collier Ditch & 381632104202001 & Collier Ditch at Hwy 50 near Avondale & DV & $\mathrm{eQco}^{4-}$ \\
\hline IR-43 & 381412104202101 & IR-43Avondale D at BR 50 near Avondale & TR & -- \\
\hline
\end{tabular}


Table 1. Site names, station names, information, and monitoring equipment information for sites in and near the Upper Arkansas River Basin and Lower Arkansas River Basin study areas, 2009-2010.-Continued

[USGS, U.S. Geological Survey; MS, main stem; TR, tributary; R, River; DV, diversion canal or ditch; WWTP, wastewater treatment plant; eQgs, existing USGS streamflow station; eQco, existing Colorado Division of Water Resources streamflow station; sQgs, seasonal USGS streamflow station; user; user supplied streamflow data; eQWgs; existing USGS water-quality station; sQWgs, seasonal USGS water-quality station; WWTP, wastewater treatment plant; CODWR; Colorado Division of Water Resources; --, no equipment]

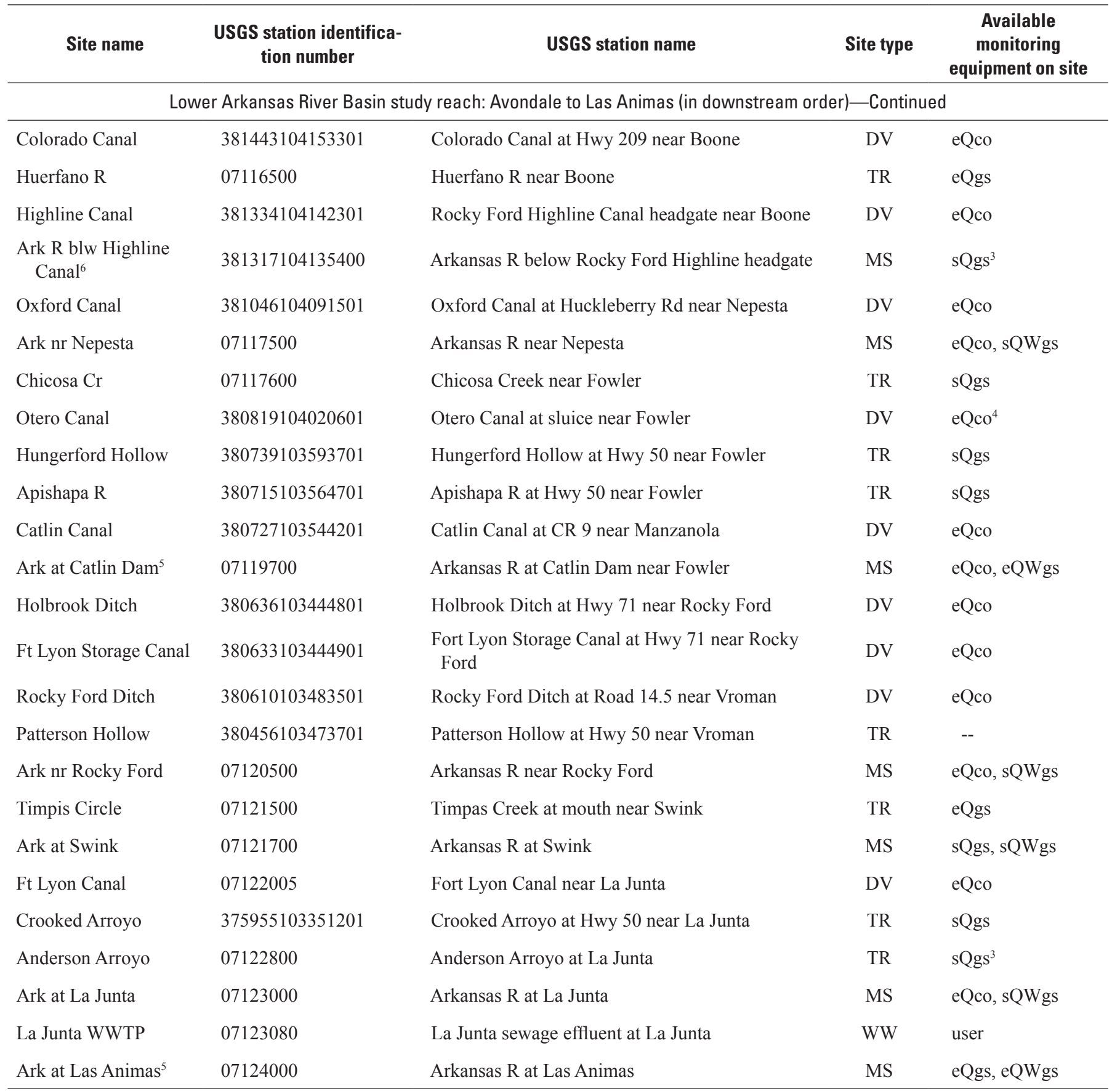

${ }^{1}$ Site data only applicable for background isotope data collected in 2009.

${ }^{2}$ Seasonal streamflow only in 2010.

${ }^{3}$ Seasonal streamflow only in 2009.

${ }^{4}$ Daily streamflow data provided by CODWR Division 2 Water Commissioner, 2010, in written communication.

${ }^{5}$ Water-quality samples only collected during synoptic sampling events. 


\section{Wastewater Treatment Plant Streamflow Data}

Data for streamflow discharged from wastewater treatment plants (WWTP) were obtained from the operators of the Rainbow Park Regional WWTP in the UARB and from the La Junta WWTP in the LARB. The Fremont Sanitation District processes wastewater from a service area that includes Canon City, Florence, and 13 State and Federal prisons at the Rainbow Park Regional WWTP. The plant discharges an average of 4.5 million gallons of treated wastewater per day to the Arkansas River (U.S. Environmental Protection Agency, 2011). The La Junta WWTP in 2010 discharged an average of 1.81 million gallons per day to the Arkansas River (U.S. Environmental Protection Agency, 2011).

\section{Available Continuous Water-Quality Monitor Data}

The USGS operated eight study-specific continuous water-quality monitors in the Arkansas River Basin during 2009-2010. Procedures for maintenance, calibration, and development of records for monitor sites are described in Wagner and others (2006). Two long-term water-quality monitoring sites on the Arkansas River are operated by the USGS in the UARB study area (fig. 2). At least 20 years of water-temperature and specific-conductance data are available for Ark at Canon City and Ark at Portland. Additionally, two water-quality monitors were installed on the main stem of the river at Ark nr Canon City and Ark nr Portland (table 1; fig. 2). The monitors were operational from July through December 2009 and from May through November 2010; daily mean water-temperature and specific-conductance values generally are available for these dates. Between December and April, icing prevented operation of the monitors.

In the LARB, three established water-quality monitoring sites are operated by the USGS on the Arkansas River (fig. 3). At least 20 years of water-temperature and specific-conductance data are available for Ark nr Avondale, Ark at Catlin Dam, and Ark at Las Animas. Additionally, one water-quality monitor was installed on the main stem of the river at Ark at Swink (table 1; fig. 3). The monitor was operational from July through December 2009 and from May through November 2010; daily mean water-temperature and specific-conductance values generally are available for these dates. Between December and April, ice prevented operation of the monitors.

\section{Water-Quality Sampling Techniques and Analytical Methodology}

Data-collection activities were conducted for two years in the two study areas. In general, water-quality samples were collected using established USGS techniques (U.S. Geological Survey, 2006) from June through December 2009 and from May through October 2010 to allow comparison of data from water-quality samples with data from specific-conductance monitors. In each study area, samples were collected periodically to characterize the water quality throughout the various hydrologic conditions observed in the Arkansas River Basin. Additionally, a limited number of synoptic (time-of-travel) sampling events were conducted to provide a better understanding of the in-stream water-quality processes using massloading analyses. Samples analyzed for dissolved constituents were filtered at the time of collection using a 0.45 -micrometer capsule filter and preserved with acid to a $\mathrm{pH}$ of 2 (U.S.

Geological Survey, 2006). Various types of quality-assurance samples also were collected in association with all the waterquality samples collected. Analytical procedures used for the analysis of water-quality samples are listed in table 2. Most water-quality samples were analyzed at the USGS National Water Quality Laboratory (NWQL) in Denver, Colo. In addition, a select number of samples were submitted to the USGS Reston Stable Isotope Laboratory in Reston, Va., for analysis of oxygen and hydrogen isotopes (Fishman and Friedman, 1989).

\section{Periodic Water-Quality Sampling}

Nine periodic water-quality sampling events were conducted in the UARB along a reach from Ark at Canon City downstream to Ark nr Portland; samples were collected between July 9, 2009, and October 7, 2010. Ten periodic sampling events were conducted in the LARB along a reach just downstream from Ark nr Avondale to Ark at La Junta; samples were collected between July 16, 2009, and October 5, 2010. Periodic samples were collected using established protocols as described in U.S. Geological Survey (2006). Field measurements of water temperature, $\mathrm{pH}$, and specific conductance were collected at main-stem and tributary sites in each of the two study areas (Wilde, F.D., variously dated), but generally only water temperature and specific conductance were measured at diversion sites. Table 3 summarizes the general types of water-quality data obtained for the 22 sampled sites in the UARB and for the 24 sampled sites in the LARB.

\section{Synoptic Water-Quality Sampling}

A limited number of synoptic (time-of-travel) sampling events were conducted to provide a better understanding of the in-stream water-quality processes using mass-loading analyses. Each synoptic sampling event used a Lagrangian sampling design, in order to follow the same parcel of water as it moves downstream (Zuellig and others, 2007). Analyses of available velocity profiles from established streamflow measuring stations were used to estimate time-of-travel between sample-collection sites (Patrick Edelmann, U.S. Geological Survey, oral commun., 2010). For this study, time-of-travel was defined as the estimated amount of elapsed time for a parcel of water to travel between two monitoring sites. Travel-time estimates were calculated several days prior to the date of sample collection using seasonally averaged velocities. Minor adjustments 
Table 2. Analytical methods for analyses of water-quality samples collected in the Arkansas River Basin study areas, 2009-2010.

$\left[{ }^{\circ} \mathrm{C}\right.$, degrees Celsius; MPN, most probable number; $\mathrm{mL}$, milliliter; S.U., standard units; $\mu \mathrm{S} / \mathrm{cm}$, microsiemens per centimeter; $\mu \mathrm{g} / \mathrm{L}, \mathrm{micrograms}$ per liter; $\mathrm{mg} / \mathrm{L}$, milligrams per liter; ICP, inductively coupled plasma; N, nitrogen; MS, mass spectrometry; AES, atomic emission spectrometer; DI-IRMS, dual inlet isotoperatio mass spectrometer]

\begin{tabular}{|c|c|c|c|}
\hline $\begin{array}{l}\text { Field parameter or } \\
\text { analyzed constituent }\end{array}$ & Analysis method & $\begin{array}{l}\text { Method reporting } \\
\text { limit }\end{array}$ & $\begin{array}{l}\text { Reporting } \\
\text { unit }\end{array}$ \\
\hline Water temperature, field & Digital thermistor & 0.5 & degrees Celsius \\
\hline $\mathrm{pH}$, field & Digital meter & 0.1 & S.U. \\
\hline Escherichia coli & Quanti-Tray ${ }^{\circledR} 2000$ & variable & MPN/ $100 \mathrm{ml}$ \\
\hline Dissolved solids & Residue on evaporation at $180{ }^{\circ} \mathrm{C}$ & 10 & $\mathrm{mg} / \mathrm{L}$ \\
\hline Calcium, dissolved & $\mathrm{ICP}$ & 0.044 & $\mathrm{mg} / \mathrm{L}$ \\
\hline Magnesium, dissolved & $\mathrm{ICP}$ & 0.016 & $\mathrm{mg} / \mathrm{L}$ \\
\hline $\begin{array}{l}\text { Acid neutralizing capacity, fixed endpoint, } \\
\text { lab determination }\end{array}$ & Electrometric titration & 8.0 & $\mathrm{mg} / \mathrm{L}$ \\
\hline Chloride, dissolved & $\mathrm{ICP}$ & 0.12 & $\mathrm{mg} / \mathrm{L}$ \\
\hline Fluoride, dissolved & $\mathrm{ICP}$ & 0.08 & $\mathrm{mg} / \mathrm{L}$ \\
\hline Silica, dissolved & Automated batch analyzer & 0.11 & $\mathrm{mg} / \mathrm{L}$ \\
\hline Ammonia plus organic nitrogen, dissolved & Colorimetric & 0.10 & $\mathrm{mg} / \mathrm{L}$, as $\mathrm{N}$ \\
\hline Ammonia, dissolved & Colorimetric & 0.020 & $\mathrm{mg} / \mathrm{L}$, as $\mathrm{N}$ \\
\hline Zinc, dissolved & ICP-MS & 2.8 & $\mu \mathrm{g} / \mathrm{L}$ \\
\hline Selenium, dissolved & ICP-MS & 0.04 & $\mu \mathrm{g} / \mathrm{L}$ \\
\hline Iron, whole water & ICP-AES & 4.6 & $\mu \mathrm{g} / \mathrm{L}$ \\
\hline Boron, dissolved & ICP-MS & 3 & $\mu \mathrm{g} / \mathrm{L}$ \\
\hline Uranium, dissolved & ICP-MS & 0.008 & $\mu \mathrm{g} / \mathrm{L}$ \\
\hline Hydrogen isotope ratio ${ }^{1}$ & DI-IRMS & variable & parts $/ 1,000$ \\
\hline Oxygen isotope ratio ${ }^{1}$ & DI-IRMS & variable & parts $/ 1,000$ \\
\hline
\end{tabular}

${ }^{1}$ Samples submitted to U.S. Geological Survey Reston Stable Isotope Laboratory. 
Table 3. Periodic water-quality sampling sites in the Upper Arkansas River Basin and Lower Arkansas River Basin study areas, 2009-2010.

[Complete site name given in table 1; MS, main stem; TR, tributary; DV, diversion canal or ditch; WWTP, wastewater treatment plant; --, none available]

\begin{tabular}{|c|c|c|c|c|c|c|c|c|c|}
\hline Site name & $\begin{array}{l}\text { Site } \\
\text { type }\end{array}$ & $\begin{array}{c}\text { Field } \\
\text { measure- } \\
\text { ments }\end{array}$ & $\begin{array}{c}\text { Major } \\
\text { ions }\end{array}$ & $\begin{array}{l}\text { Dissolved } \\
\text { solids }\end{array}$ & Nutrients & $\begin{array}{l}\text { Trace } \\
\text { metals }\end{array}$ & Boron' & Silica $^{2}$ & $\begin{array}{c}\text { Hydrogen/ } \\
\text { Oxygen } \\
\text { isotope }\end{array}$ \\
\hline \multicolumn{10}{|c|}{ Upper Arkansas River Basin study reach: Canon City to Pueblo Reservoir (in downstream order) } \\
\hline Ark at Canon City & MS & $\mathrm{x}$ & $\mathrm{x}$ & $\mathrm{x}$ & -- & $\mathrm{x}$ & -- & -- & $\mathrm{x}$ \\
\hline Sand $\mathrm{Cr}$ & $\mathrm{TR}$ & $\mathrm{x}$ & -- & $\mathrm{x}$ & -- & -- & -- & -- & -- \\
\hline Fourmile $\mathrm{Cr}$ & TR & $\mathrm{x}$ & -- & $\mathrm{x}$ & -- & $\mathrm{x}$ & -- & -- & -- \\
\hline Ark nr Canon City & MS & $\mathrm{x}$ & $\mathrm{x}$ & $\mathrm{x}$ & -- & $\mathrm{x}$ & -- & -- & $\mathrm{x}$ \\
\hline Oil Cr Ditch return & TR & $\mathrm{x}$ & -- & $\mathrm{x}$ & -- & -- & -- & -- & -- \\
\hline Minnequa Canal ${ }^{3}$ & DV & -- & -- & -- & -- & -- & -- & -- & -- \\
\hline Chandler $\mathrm{Cr}$ & $\mathrm{TR}$ & $\mathrm{x}$ & -- & $\mathrm{x}$ & -- & --- & -- & -- & -- \\
\hline Oak $\mathrm{Cr}$ & $\mathrm{TR}$ & $\mathrm{x}$ & -- & $\mathrm{x}$ & -- & -- & -- & -- & -- \\
\hline Oak Cr trib & $\mathrm{TR}$ & $\mathrm{x}$ & -- & $\mathrm{x}$ & -- & -- & -- & -- & -- \\
\hline Ark trib 2 at CR 119 & $\mathrm{TR}$ & $\mathrm{x}$ & -- & $\mathrm{x}$ & -- & $x^{4}$ & -- & -- & -- \\
\hline Ark trib 1 at CR 119 & $\mathrm{TR}$ & $\mathrm{x}$ & -- & $\mathrm{x}$ & -- & -- & -- & -- & -- \\
\hline Ark rtn at Hwy 115 & $\mathrm{TR}$ & $\mathrm{x}$ & -- & $\mathrm{x}$ & -- & -- & $\mathrm{x}$ & -- & -- \\
\hline Fremont WWTP & WW & $\mathrm{x}$ & -- & $\mathrm{x}$ & -- & $x^{5}$ & $\mathrm{x}$ & -- & $\mathrm{x}$ \\
\hline Brush Hollow & $\mathrm{TR}$ & $\mathrm{x}$ & -- & $\mathrm{x}$ & -- & $\mathrm{x}$ & -- & -- & -- \\
\hline Hardscrabble $\mathrm{Cr}$ & $\mathrm{TR}$ & $\mathrm{x}$ & -- & $\mathrm{x}$ & -- & $\mathrm{x}$ & -- & -- & -- \\
\hline Ark at Portland & MS & $\mathrm{x}$ & $\mathrm{x}$ & $\mathrm{x}$ & $\mathrm{x}$ & $\mathrm{x}$ & -- & -- & $\mathrm{x}$ \\
\hline $\mathrm{Bear} \mathrm{Cr}$ & $\mathrm{TR}$ & $\mathrm{x}$ & -- & $\mathrm{x}$ & -- & $\mathrm{x}$ & -- & -- & -- \\
\hline Ark trib 1 at CR 112 & $\mathrm{TR}$ & $\mathrm{x}$ & $\mathrm{x}$ & $\mathrm{x}$ & -- & $--^{6}$ & -- & $\mathrm{x}$ & -- \\
\hline Ark trib 2 at CR 112 & $\mathrm{TR}$ & $\mathrm{x}$ & -- & $\mathrm{x}$ & $--^{6}$ & $--^{6}$ & -- & $\mathrm{x}$ & -- \\
\hline Ark trib 1 at Hwy 120 & $\mathrm{TR}$ & $\mathrm{x}$ & -- & $\mathrm{x}$ & -- & -- & -- & -- & -- \\
\hline Ranger $\mathrm{Cr}$ & $\mathrm{TR}$ & $\mathrm{x}$ & -- & $\mathrm{x}$ & -- & $\mathrm{x}^{4}$ & -- & -- & -- \\
\hline Beaver $\mathrm{Cr}$ & TR & $\mathrm{x}$ & -- & $\mathrm{x}$ & -- & -- & -- & -- & -- \\
\hline Ark nr Portland & MS & $\mathrm{x}$ & $\mathrm{x}$ & $\mathrm{x}$ & $\mathrm{x}$ & $\mathrm{x}$ & -- & -- & $\mathrm{x}$ \\
\hline
\end{tabular}

Lower Arkansas River Basin study reach: Avondale to Las Animas (in downstream order)

$\begin{array}{lcc}\text { Sixmile Cr } & \text { TR } & \mathrm{x} \\ \text { Collier Ditch } & \text { DV } & \mathrm{x}^{7} \\ \text { IR-43 } & \text { TR } & \mathrm{x} \\ \text { Colorado Canal } & \text { DV } & \mathrm{x}^{7} \\ \text { Highline Canal } & \text { DV } & \mathrm{x}^{7} \\ \text { Oxford Canal } & \text { DV } & \mathrm{x}^{7} \\ \text { Ark nr Nepesta } & \text { MS } & \mathrm{x} \\ \text { Chicosa Cr } & \text { TR } & \mathrm{x} \\ \text { Otero Canal } & \text { DV } & \mathrm{x}^{7}\end{array}$


Table 3. Periodic water-quality sampling sites in the Upper Arkansas River Basin and Lower Arkansas River Basin study areas, 2009-2010.-Continued

[Complete site name given in table 1; MS, main stem; TR, tributary; DV, diversion canal or ditch; WWTP, wastewater treatment plant; --, none available]

\begin{tabular}{|c|c|c|c|c|c|c|c|c|c|}
\hline Site name & $\begin{array}{l}\text { Site } \\
\text { type }\end{array}$ & $\begin{array}{c}\text { Field } \\
\text { measure- } \\
\text { ments }\end{array}$ & $\begin{array}{c}\text { Major } \\
\text { ions }\end{array}$ & $\begin{array}{l}\text { Dissolved } \\
\text { solids }\end{array}$ & Nutrients & $\begin{array}{c}\text { Trace } \\
\text { metals }\end{array}$ & Boron $^{1}$ & Silica $^{2}$ & $\begin{array}{c}\text { Hydrogen/ } \\
\text { Oxygen } \\
\text { isotope }\end{array}$ \\
\hline \multicolumn{10}{|c|}{ Lower Arkansas River Basin study reach: Avondale to Las Animas (in downstream order)—Continued } \\
\hline Hungerford Hollow & $\mathrm{TR}$ & $\mathrm{x}$ & -- & $\mathrm{x}$ & -- & $\mathrm{x}^{4}$ & -- & $\mathrm{x}^{4}$ & -- \\
\hline Apishapa R & TR & $\mathrm{x}$ & -- & $\mathrm{x}$ & -- & $x^{4}$ & -- & $x^{4}$ & -- \\
\hline Holbrook Ditch & DV & $\mathrm{x}^{7}$ & -- & -- & -- & -- & -- & -- & -- \\
\hline Ft Lyon Storage Canal & DV & $x^{7}$ & -- & -- & -- & -- & -- & -- & -- \\
\hline Rocky Ford Ditch & DV & $x^{7}$ & -- & -- & -- & -- & -- & -- & -- \\
\hline Patterson Hollow & $\mathrm{TR}$ & $\mathrm{x}$ & -- & $\mathrm{x}$ & -- & $x^{4}$ & -- & $x^{4}$ & -- \\
\hline Ark at Swink & MS & $\mathrm{x}$ & $\mathrm{x}$ & $\mathrm{x}$ & $\mathrm{x}$ & $\mathrm{x}$ & $\mathrm{x}$ & $\mathrm{x}$ & $\mathrm{x}$ \\
\hline Ft Lyon Canal & DV & $x^{7}$ & -- & -- & -- & -- & -- & -- & -- \\
\hline Crooked Arroyo & $\mathrm{TR}$ & $\mathrm{x}$ & -- & $\mathrm{x}$ & -- & $x^{4}$ & -- & $x^{4}$ & -- \\
\hline Anderson Arroyo & $\mathrm{TR}$ & $\mathrm{x}$ & -- & $\mathrm{x}$ & -- & $x^{4}$ & -- & $x^{4}$ & -- \\
\hline Ark at La Junta & MS & $\mathrm{x}$ & $\mathrm{x}$ & $\mathrm{x}$ & $\mathrm{x}$ & $\mathrm{x}$ & $\mathrm{x}$ & $\mathrm{x}$ & $\mathrm{x}$ \\
\hline La Junta WWTP ${ }^{8}$ & WW & $\mathrm{x}$ & -- & $\mathrm{x}$ & -- & $\mathrm{x}$ & $\mathrm{x}$ & -- & $\mathrm{x}$ \\
\hline
\end{tabular}

${ }^{1}$ Dissolved boron data only collected in 2009.

${ }^{2}$ Dissolved silica data only collected in 2010 .

${ }^{3}$ No samples were collected at this site; water-quality data from Ark nr Canon City were used as a surrogate.

${ }^{4}$ Selected constituents sampled no more than twice at this site for regional characterization purposes.

${ }^{5}$ Selenium was the only trace metal targeted at the Fremont County wastewater treatment plant.

${ }^{6}$ Requested analyses were not completed due to sample loss at the U.S. Geological Survey National Water Quality Laboratory.

${ }^{7}$ Field measurements included water temperature and specific conductance but not $\mathrm{pH}$.

${ }^{8}$ Samples collected only in 2009 at the La Junta WWTP. 
were made to the estimates just prior to the synoptic event using available real-time data. In general, sampling times for tributary and diversion sites were scheduled to coincide with the sampling time for the main-stem parcel of water in the Arkansas River.

Synoptic sampling events in the UARB occurred on September 2, 2009, June 22, 2010, July 20, 2010, and September 15, 2010. During each sampling event, samples were collected during a single day along the main-stem reach of the Arkansas River (approximately $23 \mathrm{mi}$ ) as determined by the estimates of travel time between sites. Tributary sites were sampled accordingly, given the travel-time estimates. Equalwidth incremental sampling techniques were used to collect a representative sample when streamflow conditions allowed. During high-flow conditions, bank sampling or multiple vertical techniques were used to ensure the safety of the sampling crews. Sampling techniques used in this study are described in U.S. Geological Survey (2006). A list of sampling sites and general types of analyses can be found in table 4 . The analytical list of constituents is similar to those for the periodic sampling in the UARB (table 3); however, analyses of Escherichia coli and total coliform bacteria were included as part of the synoptic effort. Nutrient samples requiring refrigeration and time-dependent samples generally were not collected as part of the synoptic sampling events.

Synoptic sampling events in the LARB occurred on October 20-23, 2009, November 16-19, 2009, June 8-10, 2010, and August 17-20, 2010. Samples were collected over the course of several days as determined by estimates of travel time between sites; the overall length of this river reach was approximately $76 \mathrm{mi}$. Tributary and diversion sites were assigned sample times to coincide with the estimated sampling time for the Arkansas River main-stem parcel at the mouth of the tributary or diversion site.

Synoptic sampling in the LARB was problematic for several reasons, and as such, the approach taken for sampling this study area was substantially different than that followed for the UARB. The study reach was too long to allow for typical synoptic sampling techniques because some of the scheduled sampling times were at night, creating a substantial safety hazard for the sampling crews. Additionally, water operations in the LARB are highly variable. Releases from Pueblo Reservoir and calls for diversions to canals and ditches can quickly and substantially change streamflow conditions in the Arkansas River. In order to circumvent these issues, automated samplers were used at main-stem sites to collect a single composited sample over a 24-hour period (one sample aliquot collected every 2 hours). This sampling strategy resulted in the collection of a sample that represented a daily mean concentration of analytes that would be less susceptible to short temporal changes in streamflow.

Composited 24-hour samples were not collected at tributary sites. These sites were less susceptible to large changes in streamflow and generally were considered to be in a "quasi" steady-state condition over the course of the sampling period. As such, synoptic sampling of tributary sites in the LARB was scheduled to coincide as closely as practical with the estimated arrival time of the main-stem parcel being sampled at the mouth of a tributary, and the collected samples were assumed to represent a daily mean concentration.

\section{Statistical Analyses}

The nonparametric Kruskall-Wallis test was used to determine whether there were statistically significant differences in median concentrations of constituents (such as, dissolved solids, dissolved selenium, and dissolved uranium) and dissolved-solids loads between selected sites. Nonparametric analysis allows the user to analyze data without assuming an underlying distribution (Helsel and Hirsch, 2002). The probability value ( $p$-value) is the probability of rejecting the null hypothesis if it is true. A p-value of less than 0.05 was used in this report to indicate if a statistical test was significant and reject the null hypothesis. The nonparametric MannWhitney test examines the equality of two population medians. A confidence coefficient of 0.95 and error level of test $\alpha=$ 0.05 was selected for the test. As with the Kruskall-Wallis test, a p-value of less than 0.05 is significant and the null hypothesis is rejected. A nonparametric multiple-comparison Tukey's test (Helsel and Hirsch, 2002) was used to determine significant differences between sampling sites on the main stem of the Arkansas River if the results of the Kruskall-Wallis test indicated significant differences in constituent concentrations or loads between selected sites.

Simple linear regression was used to determine the best straight-line fit between two variables (one dependent and one independent variable) and obtain a predictive equation. The coefficient of determination, $r$-squared $\left(r^{2}\right)$, is a statistical measure of how well the predictive equation (regression line) fits the real data points (Helsel and Hirsch, 2002). It varies between 0 and 1 and indicates the amount of variability in the dependent variable described by the independent variable (an $\mathrm{r}^{2}$ value of 0 indicates that there is no relation between the dependent and independent variables; and an $\mathrm{r}^{2}$ value of 1 indicates that there is a perfect relation between the dependent and independent variables). The range and description of $\mathrm{r}^{2}$ in this report is 0 to 0.50 is weak, 0.51 to 0.85 is moderate, and greater than 0.86 is a strong correlation.

\section{Quality-Assurance Procedures}

Quality-assurance procedures followed USGS protocols (U.S. Geological Survey, 2006), and quality assurance/ quality-control samples accounted for about 10 percent of the total number of samples collected in the study. Part per-billion collection protocols (U.S. Geological Survey, 2006) were used for equipment cleaning and handling, sample and blank collection, and field-processing procedures to minimize contamination and bias. Equal-width increment (EWI) samples collected by USGS personnel and point samples collected by automated samplers were compared to evaluate any potential 
Table 4. Synoptic water-quality sampling sites in the Upper Arkansas River Basin and Lower Arkansas River Basin study areas, 2009-2010.

[Complete site name given in table 1; E. coli, Escherichia coli; MS, main stem; TR, tributary; DV, diversion canal or ditch; WWTP, wastewater treatment plant; --, none available]

\begin{tabular}{|c|c|c|c|c|c|c|c|c|c|c|c|}
\hline Site name & $\begin{array}{l}\text { Site } \\
\text { type }\end{array}$ & $\begin{array}{c}\text { Field } \\
\text { measure- } \\
\text { ments }\end{array}$ & $\begin{array}{l}\text { Major } \\
\text { ions }\end{array}$ & $\begin{array}{l}\text { Dissolved } \\
\text { solids }\end{array}$ & $\begin{array}{l}\text { Nutri- } \\
\text { ents }\end{array}$ & $\begin{array}{c}\text { Trace } \\
\text { metals }\end{array}$ & Boron ${ }^{1}$ & Silica ${ }^{2}$ & $\begin{array}{c}\text { Hydrogen/ } \\
\text { oxygen } \\
\text { isotope }\end{array}$ & E. coli & $\begin{array}{c}\text { Total } \\
\text { coliform } \\
\text { bacteria }\end{array}$ \\
\hline \multicolumn{12}{|c|}{ Upper Arkansas River Basin study reach: Canon City to Pueblo Reservoir (in downstream order) } \\
\hline Ark at Canon City & MS & $\mathrm{x}$ & $\mathrm{x}$ & $\mathrm{x}$ & -- & $\mathrm{x}$ & $\mathrm{x}$ & $\mathrm{x}$ & $\mathrm{x}$ & $\mathrm{x}$ & $\mathrm{x}$ \\
\hline Sand $\mathrm{Cr}$ & TR & $\mathrm{x}$ & -- & $\mathrm{x}$ & -- & -- & -- & $\mathrm{x}$ & $\mathrm{x}$ & $\mathrm{x}$ & $\mathrm{x}$ \\
\hline Ark nr Canon City & MS & $\mathrm{x}$ & $\mathrm{x}$ & $\mathrm{x}$ & -- & $\mathrm{x}$ & $\mathrm{x}$ & $\mathrm{x}$ & $\mathrm{x}$ & $\mathrm{x}$ & $\mathrm{x}$ \\
\hline Oil Cr Ditch return & TR & $\mathrm{x}$ & -- & $\mathrm{x}$ & -- & -- & -- & -- & $\mathrm{x}$ & $\mathrm{x}$ & $\mathrm{x}$ \\
\hline Minnequa Canal $^{3}$ & DV & -- & -- & -- & -- & -- & -- & -- & -- & -- & -- \\
\hline Chandler Cr & $\mathrm{TR}$ & $\mathrm{x}$ & -- & $\mathrm{x}$ & -- & -- & -- & $\mathrm{x}$ & $\mathrm{x}$ & $\mathrm{x}$ & $\mathrm{x}$ \\
\hline Ark trib 2 at CR 119 & TR & $\mathrm{x}$ & -- & $\mathrm{x}$ & -- & -- & -- & -- & $\mathrm{x}$ & $\mathrm{x}$ & $\mathrm{x}$ \\
\hline Ark trib 1 at CR 119 & TR & $\mathrm{x}$ & -- & $\mathrm{x}$ & -- & -- & -- & $\mathrm{x}$ & $\mathrm{x}$ & $\mathrm{x}$ & $\mathrm{x}$ \\
\hline Ark rtn at Hwy 115 & TR & $\mathrm{x}$ & $x^{4}$ & $\mathrm{x}$ & -- & $\mathrm{x}^{4}$ & $\mathrm{x}^{4}$ & $x^{4}$ & $\mathrm{x}$ & $\mathrm{x}$ & $\mathrm{x}$ \\
\hline Fremont WWTP & WW & $\mathrm{x}$ & -- & $\mathrm{x}$ & -- & $x^{5}$ & -- & -- & $\mathrm{x}$ & $\mathrm{x}$ & $\mathrm{x}$ \\
\hline Brush Hollow & TR & $\mathrm{x}$ & -- & $\mathrm{x}$ & -- & -- & -- & $\mathrm{x}$ & $\mathrm{x}$ & $\mathrm{x}$ & $\mathrm{x}$ \\
\hline Hardscrabble Cr & TR & $\mathrm{x}$ & -- & $\mathrm{x}$ & -- & -- & -- & $\mathrm{x}$ & $\mathrm{x}$ & $\mathrm{x}$ & $\mathrm{x}$ \\
\hline Ark at Portland & MS & $\mathrm{x}$ & $\mathrm{x}$ & $\mathrm{x}$ & $\mathrm{x}$ & $\mathrm{x}$ & $\mathrm{x}$ & $\mathrm{x}$ & $\mathrm{x}$ & $\mathrm{x}$ & $\mathrm{x}$ \\
\hline Beaver $\mathrm{Cr}$ & TR & $\mathrm{x}$ & -- & $\mathrm{x}$ & -- & -- & -- & $\mathrm{x}$ & $\mathrm{x}$ & $\mathrm{x}$ & $\mathrm{x}$ \\
\hline Ark nr Portland & MS & $\mathrm{x}$ & $\mathrm{x}$ & $\mathrm{x}$ & $\mathrm{x}$ & $\mathrm{x}$ & $\mathrm{x}$ & $\mathrm{x}$ & $\mathrm{x}$ & $\mathrm{x}$ & $\mathrm{x}$ \\
\hline
\end{tabular}

Lower Arkansas River Basin study reach: Avondale to Las Animas (in downstream order)

\begin{tabular}{|c|c|c|c|c|c|c|c|c|c|c|c|}
\hline Ark nr Avondale & MS & $\mathrm{x}$ & $\mathrm{x}$ & $\mathrm{x}$ & -- & $\mathrm{x}$ & $\mathrm{x}$ & $\mathrm{x}$ & $\mathrm{x}$ & $\mathrm{x}$ & $\mathrm{x}$ \\
\hline Sixmile $\mathrm{Cr}$ & $\mathrm{TR}$ & $\mathrm{x}$ & $\mathrm{x}$ & $\mathrm{x}$ & $\mathrm{x}^{4}$ & $\mathrm{x}$ & $\mathrm{x}$ & $\mathrm{x}$ & $\mathrm{x}$ & $\mathrm{x}$ & $\mathrm{x}$ \\
\hline Collier Ditch & DV & $x^{6}$ & -- & $\mathrm{x}$ & -- & $\mathrm{x}$ & -- & -- & $\mathrm{x}$ & -- & -- \\
\hline IR-43 & $\mathrm{TR}$ & $\mathrm{x}$ & $\mathrm{x}$ & $\mathrm{x}$ & $\mathrm{x}^{4}$ & $\mathrm{x}$ & $\mathrm{x}$ & $\mathrm{x}$ & $\mathrm{x}$ & $\mathrm{x}$ & $\mathrm{x}$ \\
\hline Colorado Canal & DV & $x^{6}$ & -- & $\mathrm{x}$ & -- & $\mathrm{x}$ & -- & -- & $\mathrm{x}$ & -- & -- \\
\hline Huerfano R & $\mathrm{TR}$ & $\mathrm{x}$ & $\mathrm{x}$ & $\mathrm{x}$ & $\mathrm{x}^{4}$ & $\mathrm{x}$ & $\mathrm{x}$ & $\mathrm{x}$ & $\mathrm{x}$ & $\mathrm{x}$ & $\mathrm{x}$ \\
\hline Highline Canal & DV & $x^{6}$ & -- & $\mathrm{x}$ & -- & $\mathrm{x}$ & -- & -- & $\mathrm{x}$ & -- & -- \\
\hline
\end{tabular}


Table 4. Synoptic water-quality sampling sites in the Upper Arkansas River Basin and Lower Arkansas River Basin study areas, 2009-2010.-Continued

[Complete site name given in table 1; E. coli, Escherichia coli; MS, main stem; TR, tributary; DV, diversion canal or ditch; WWTP, wastewater treatment plant; --, none available]

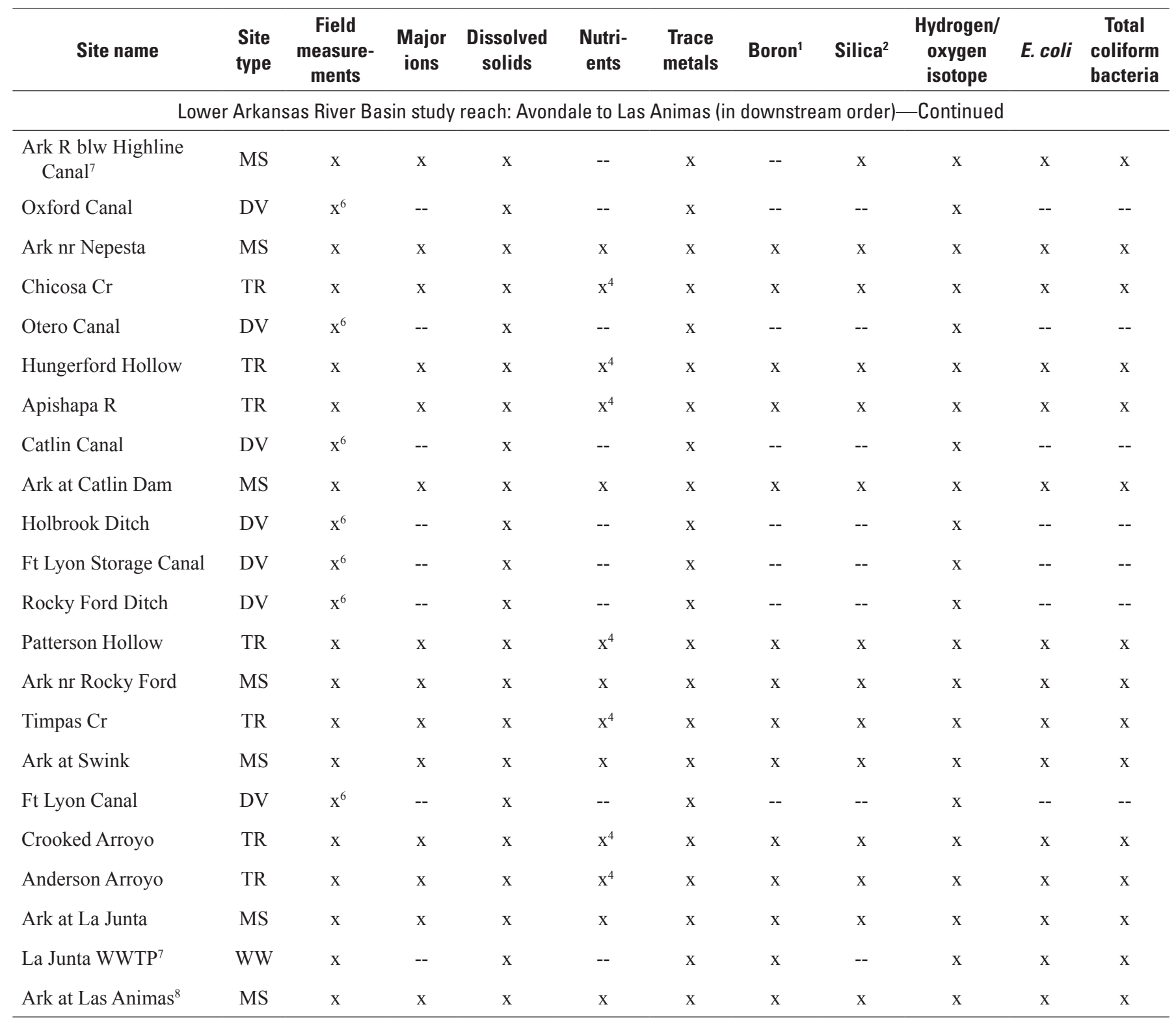

${ }^{1}$ Dissolved boron data only collected in 2009.

${ }^{2}$ Dissolved silica data only collected in 2010 .

${ }^{3}$ No samples were collected at this site; water-quality data from Ark nr Canon City were used as a surrogate.

${ }^{4}$ Selected constituents sampled once at this site for regional characterization purposes.

${ }^{5}$ Selenium was the only trace metal targeted at the Rainbow Park regional wastewater treatment plant.

${ }^{6}$ Field measurements included water temperature and specific conductance but not $\mathrm{pH}$.

${ }^{7}$ Only sampled in 2009.

${ }^{8}$ Synoptic sampling at Ark at Las Animas did not use automated pumping sampler. 
sampling bias associated with the location of the automated sampler intakes and any variations in sample chemistry relative to samples collected from the entire channel cross section. Water-quality-assurance samples were analyzed by the USGS National Water-Quality Laboratory (NWQL), Denver, Colorado.

Field-blank and field-split samples were collected to evaluate potential sample contamination and variability associated with sampling processing (U.S Geological Survey, 2006). As part of this study, four field-blank quality-assurance samples were collected. Field blanks are collected and processed at the field site in the same manner and using the same equipment as the environmental samples except inorganic-free blank water was used instead of an environmental sample. Certified inorganic-free blank water was obtained from the NWQL. Field blanks are used to evaluate the potential for sample contamination as a consequence of equipment cleaning and handling, sample collection, and (or) laboratory procedures. Field blank analyses (table 5) indicated that equipment cleaning and handling protocols, field sampling, and laboratory processing procedures were generally effective in preventing or minimizing contamination of water-quality samples collected. Most constituents analyzed in field blanks were not quantified and were reported as a less than value.

One field blank indicated potential contamination for one dissolved constituent: ammonia, as nitrogen $(0.036 \mathrm{mg} / \mathrm{L})$. This field-blank concentration represented about 65 to 80 percent of the dissolved ammonia present in the environmental sample ( $0.054 \mathrm{mg} / \mathrm{L}$ as nitrogen and $0.057 \mathrm{mg} / \mathrm{L}$ as ammonia). The source of ammonia contamination in this field blank is unclear. Concentrations of other nitrogen-based nutrient constituents analyzed were below laboratory reporting levels, and specific blanks that targeted different steps along the processing procedure were not collected. However, several potential sources of ammonia have been identified. Animal manure odor from local feedlots and (or) areas of manure application were present during numerous site inspections, and ammonia is contained in animal manure odor (McGinn and others, 2003). Whether or not airborne ammonia concentrations were noticeable during sampling on the date of concern was not noted; however, sample contamination by short-term exposure to airborne ammonia, if present, could possibly contribute to the concentrations observed in the field blank. Contamination during field and (or) laboratory procedures also is a possibility. Increasing the number of blank samples with nutrient analyses may be a benefit to future sampling efforts. The additional nutrient analyses would permit evaluation of ammonia contamination as an isolated occurrence or a systemic problem. Also, the addition of blank samples that target procedural steps could potentially provide insight into contamination sources.

Eighteen split samples were collected and processed in the field to evaluate variability in sample concentration as a function of sample processing. The relative-percent difference (RPD) between split samples was computed when the constituent concentration of each respective subsample was greater than the laboratory reporting level: where

$$
R P D=\left(\frac{\frac{R_{1}-R_{2}}{R_{1}+R_{2}}}{2}\right) * 100
$$

$$
\begin{array}{cl}
R P D & \text { is relative percent difference, } \\
R_{1} & \text { is concentration of split sample } \\
R_{2} & \text { is concentration of split sample } 2 .
\end{array}
$$

Ten field-split sample pairs were evaluated for differences in concentration of nutrients (table 6). RPDs of concentrations of most split pairs were very similar; 96.3 percent of split pair concentrations varied by less than 5 percent. RPDs of concentrations of ammonia, as N, varied by 10.00 percent, and represented the only occurrence of RPDs between nutrient concentrations in field-split sample pairs greater than 5 percent. The large RPDs of ammonia concentrations, as $\mathrm{N}$, were disregarded due to the possible sample contamination as previously described. Sixteen field-split samples were evaluated for differences in concentration of major, minor, and trace inorganics. RPDs of major inorganic concentration of all field-split sample pairs were less than 2.5 percent. RPDs of minor and trace inorganic concentration were less than 5 percent in 24 of 26 sample pairs (92.3 percent). Eighteen field-split samples were evaluated for differences in physical properties. RPD in physical properties of all field-split sample pairs varied by less than 5 percent. Sixteen field-split samples were evaluated for differences in concentration of uranium. RPDs of uranium concentration of 15 of 16 (93.8 percent) field-split sample pairs were less than 5 percent. Based on the low occurrence of RPD greater than 5 percent in constituent concentrations in field-split sample pairs, sample-processing procedures were considered to be consistent and to have minimal effect on constituent concentrations, with the exception of ammonia.

Differences in sampling methods can introduce bias into a data set. Two methods were used to collect water-quality samples - depth-integrated EWI and discrete-point sampling. The EWI method involves collection of a depth-integrated sample at discrete intervals across the entire width of the channel. The discrete-point sampling consists of water collected at one discrete point, generally close to the stream bank, by an automated pumping sampler. The primary source of potential bias between the two sampling methods was identified as unequal mixing of dissolved and suspended constituents with depth and across the width of the channel at the sampling site. To evaluate potential bias based on differences in sampling methods, $18 \mathrm{EWI} /$ point-sample pairs were collected (table 7). Two or more sample pairs were collected at most sites. Computed RPDs were used to evaluate differences in dissolved selenium concentrations and SC in EWI and point samples.

An evaluation of the differences between the EWI- and point-sample concentrations indicates point-sample concentrations of dissolved selenium generally were larger than the dissolved selenium concentration in the associated EWI sample for each station. Point-sample concentrations were 
Table 5. Results of field blank quality-assurance samples collected in the Arkansas River Basin study areas, 2009-2010.

$[\mathrm{mg} / \mathrm{L}$, milligrams per liter; N, nitrogen; $\mathrm{P}$, phosphorus; ANC, acid neutralizing capacity; <, less than; $\mu \mathrm{g} / \mathrm{L}$, micrograms per liter; NA, not analyzed]

\begin{tabular}{|c|c|c|c|c|}
\hline \multirow{3}{*}{$\begin{array}{c}\begin{array}{c}\text { Field measurement or analyzed } \\
\text { constituents }\end{array} \\
\text { Date }\end{array}$} & \multicolumn{4}{|c|}{ Station identification number } \\
\hline & 07121700 & 07121700 & 07109500 & 38133410414230 \\
\hline & $12 / 16 / 2009$ & $6 / 29 / 2010$ & $8 / 17 / 2010$ & $11 / 16 / 2009$ \\
\hline Ammonia, $\mathrm{mg} / \mathrm{L}$ as $\mathrm{N}$ & NA & 0.036 & NA & NA \\
\hline Nitrite, $\mathrm{mg} / \mathrm{L}$ as $\mathrm{N}$ & NA & $<0.002$ & NA & NA \\
\hline $\begin{array}{l}\text { Ammonia plus organic nitrogen, } \\
\mathrm{mg} / \mathrm{L} \text { as } \mathrm{N}\end{array}$ & NA & $<0.1$ & NA & NA \\
\hline Nitrite plus nitrate, $\mathrm{mg} / \mathrm{L}$ as $\mathrm{N}$ & $<0.04$ & $<0.016$ & NA & NA \\
\hline Phosphorus, mg/L & NA & $<0.008$ & NA & NA \\
\hline Orthophosphate, $\mathrm{mg} / \mathrm{L}$ as $\mathrm{P}$ & NA & $<0.008$ & NA & NA \\
\hline Calcium, mg/L & $<0.04$ & $<0.04$ & $<0.04$ & NA \\
\hline Magnesium, mg/L & $<0.016$ & $<0.016$ & $<0.016$ & NA \\
\hline Sodium, $\mathrm{mg} / \mathrm{L}$ & $<0.1$ & $<0.1$ & $<0.1$ & NA \\
\hline Potassium,mg/L & $<0.06$ & $<0.06$ & $<0.06$ & NA \\
\hline Chloride, $\mathrm{mg} / \mathrm{L}$ & $<0.12$ & $<0.12$ & $<0.12$ & NA \\
\hline Sulfate, $\mathrm{mg} / \mathrm{L}$ & $<0.18$ & $<0.18$ & $<0.18$ & NA \\
\hline Fluoride, mg/L & $<0.08$ & $<0.08$ & $<0.08$ & NA \\
\hline Silica, $\mathrm{mg} / \mathrm{L}$ & NA & $<0.1$ & $<0.1$ & NA \\
\hline $\mathrm{ANC}$ & $<8$ & $<8$ & $<8$ & NA \\
\hline Boron, $\mu \mathrm{g} / \mathrm{L}$ & $<3$ & NA & NA & NA \\
\hline Zinc, $\mu \mathrm{g} / \mathrm{L}$ & NA & $<2.8$ & NA & NA \\
\hline Aluminum, $\mu \mathrm{g} / \mathrm{L}$ & NA & $<3.4$ & NA & NA \\
\hline Selenium, $\mu \mathrm{g} / \mathrm{L}$ & $<0.04$ & $<0.04$ & $<0.04$ & $<0.04$ \\
\hline Residue on evaporation, $\mathrm{mg} / \mathrm{L}$ & $<10$ & $<10$ & $<10$ & $<10$ \\
\hline Uranium (natural), $\mu \mathrm{g} / \mathrm{L}$ & $<0.01$ & $<0.01$ & $<0.01$ & $<0.01$ \\
\hline
\end{tabular}


Table 6. Relative percent difference between replicate quality-assurance samples collected in the Arkansas River Basin study areas, 2009-2010.

[ID, identification number; sites listed in table $1 ; \mathrm{mg} / \mathrm{L}$, milligrams per liter; $\mathrm{N}$, nitrogen; $\mathrm{P}$, phosphorus; $\mathrm{NH}_{4}$, ammonia; ANC, acid neutralizing capacity; $\mu \mathrm{g} / \mathrm{L}$, micrograms per liter; red values indicate relative percent difference greater than 5 percent;--, not applicable]

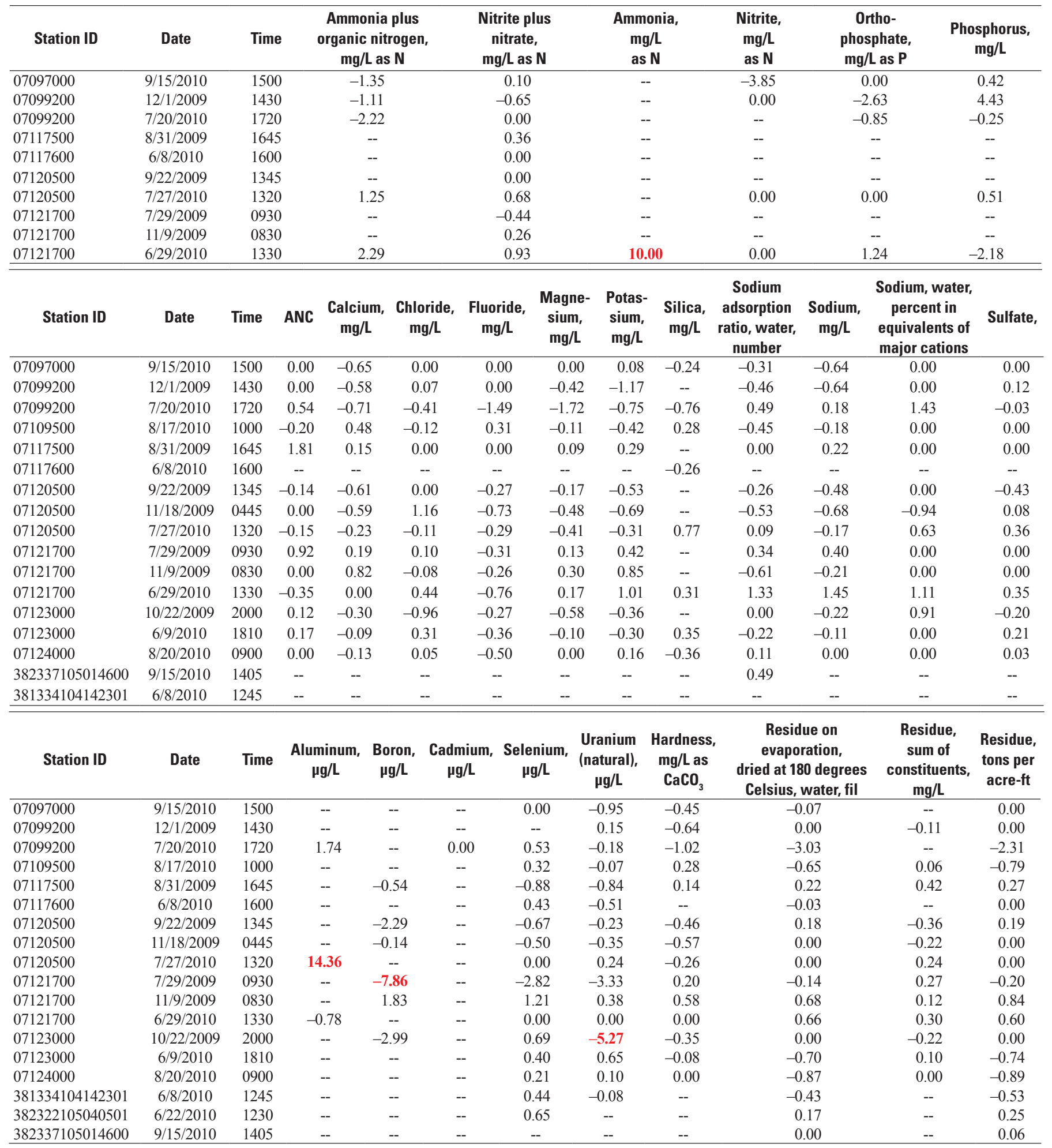


Table 7. Relative percent differences in concentration of dissolved selenium and specific conductance between equal width increment and discrete-point samples collected in the Arkansas River Basin study areas, 2009-2010.

$\left[\mathrm{ID}\right.$, identification number; RPD, relative percent difference; $\mu \mathrm{g} / \mathrm{L}$, microgram per liter; $\mu \mathrm{S} / \mathrm{cm}$, microsiemens per centimeter; ${ }^{\circ} \mathrm{C}$, degree Celsius; EWI, equal width increment; PNT, point; Rmk, remark; $(+)$, positive bias, discrete-point-sample concentration generally greater than EWI sample concentration; $(-)$, negative bias, discrete-point-sample concentration generally less than EWI sample concentration; sites listed in table 1]

\begin{tabular}{|c|c|c|c|c|c|c|c|c|c|c|}
\hline $\begin{array}{c}\text { Station } \\
\text { identification } \\
\text { number }\end{array}$ & Date & $\begin{array}{l}\text { Sample } \\
\text { type }\end{array}$ & $\begin{array}{l}\text { Concentra- } \\
\text { tion }\end{array}$ & $\begin{array}{l}\text { Sample } \\
\text { type }\end{array}$ & $\begin{array}{l}\text { Concentra- } \\
\text { tion }\end{array}$ & Rmk & RPD & $\begin{array}{l}\text { Average } \\
\text { RPD }\end{array}$ & $\begin{array}{c}\text { Point } \\
\text { sample } \\
\text { bias for sta- } \\
\text { tion }\end{array}$ & $\begin{array}{c}\text { Concentra- } \\
\text { tion } \\
\text { difference }\end{array}$ \\
\hline 07109500 & $10 / 20 / 2009$ & EWI & 13.1 & PNT & 13.5 & & -3.01 & & & -0.4 \\
\hline 07109500 & $11 / 16 / 2009$ & EWI & 13.1 & PNT & 14.0 & & -6.64 & -5.69 & $(+)$ & -0.9 \\
\hline 07117500 & $10 / 20 / 2009$ & EWI & 10.7 & PNT & 8.5 & & 22.9 & & & 2.2 \\
\hline 07117500 & $11 / 16 / 2009$ & EWI & 11.7 & PNT & 11.4 & & 2.60 & 6.93 & $(-)$ & 0.3 \\
\hline 07117500 & 8/17/2010 & EWI & 6.2 & PNT & 6.5 & & -4.72 & & & -0.3 \\
\hline 07119700 & $10 / 20 / 2009$ & EWI & 8.8 & PNT & 9.1 & & -3.35 & 771 & $(+)$ & -0.3 \\
\hline 07119700 & $11 / 16 / 2009$ & EWI & 10.9 & PNT & 12.3 & & -12.1 & -1.11 & (i) & -1.4 \\
\hline 07121700 & $10 / 22 / 2009$ & EWI & 10.3 & PNT & 12.2 & & -16.9 & & & -1.9 \\
\hline 07121700 & $11 / 18 / 2009$ & EWI & 16.6 & PNT & 19.3 & & -15.0 & -13.6 & $(+)$ & -2.7 \\
\hline 07121700 & $8 / 19 / 2010$ & EWI & 10.9 & PNT & 11.9 & & -8.77 & & & -1.0 \\
\hline 07123000 & $10 / 22 / 2009$ & EWI & 11.5 & PNT & 11.4 & & 0.87 & & & 0.1 \\
\hline 07123000 & $11 / 19 / 2009$ & EWI & 17.5 & PNT & 17.4 & & 0.57 & 1.39 & $(-)$ & 0.1 \\
\hline 07123000 & $8 / 19 / 2010$ & EWI & 11.2 & PNT & 10.9 & & 2.71 & & & 0.3 \\
\hline \multirow[t]{2}{*}{381317104135400} & $8 / 17 / 2010$ & EWI & 7.7 & PNT & 7.9 & & -2.56 & & & -0.2 \\
\hline & & \multicolumn{9}{|c|}{$\frac{\text { Specific conductance, in } \mu \mathrm{S} /}{\underline{\mathrm{cm} \text { at } 25^{\circ} \mathrm{C}}}$} \\
\hline 07119700 & $10 / 20 / 2009$ & EWI & 985 & PNT & 1110 & & -11.9 & \multirow{2}{*}{-8.38} & \multirow{2}{*}{$(+)$} & -125 \\
\hline 07119700 & $11 / 16 / 2009$ & EWI & 1010 & PNT & 1060 & & -4.83 & & & -50 \\
\hline 07120500 & $10 / 21 / 2009$ & EWI & 1240 & PNT & 1310 & & -5.49 & \multirow{3}{*}{-3.18} & \multirow{3}{*}{$(+)$} & -70 \\
\hline 07120500 & $11 / 17 / 2009$ & EWI & 1400 & PNT & 1410 & & -0.71 & & & -10 \\
\hline 07120500 & $8 / 19 / 2010$ & EWI & 1180 & PNT & 1220 & & -3.33 & & & -40 \\
\hline 07121700 & $10 / 22 / 2009$ & EWI & 1290 & PNT & 1530 & & -17.0 & \multirow{2}{*}{-10.3} & \multirow{2}{*}{$(+)$} & -240 \\
\hline 07121700 & $11 / 18 / 2009$ & EWI & 1860 & PNT & 2140 & & -14.0 & & & -280 \\
\hline 07121700 & $8 / 19 / 2010$ & EWI & 1310 & PNT & 1310 & & 0.00 & & & 0 \\
\hline 07123000 & $10 / 22 / 2009$ & EWI & 1530 & PNT & 1550 & & -1.30 & & & -20 \\
\hline 07123000 & $11 / 19 / 2009$ & EWI & 2090 & PNT & 2100 & & -0.48 & -1.06 & $(+)$ & -10 \\
\hline 07123000 & $8 / 19 / 2010$ & EWI & 1410 & PNT & 1430 & & -1.41 & & & -20 \\
\hline 381317104135400 & $8 / 17 / 2010$ & EWI & 753 & PNT & 767 & & -1.84 & & & -14 \\
\hline
\end{tabular}


larger than the associated EWI sample concentration in 13 of 18 sample pairs. However, the range in the absolute values of the differences was small, 0.1 to $2.7 \mu \mathrm{g} / \mathrm{L}$. RPDs were greater than 5 percent in 8 of 18 samples. The perceived large RPDs (greater than 5 percent) between concentrations of eight EWI and point-sample pairs is an artifact of the very small concentrations measured in the EWI and point samples; large RPDs can be reported from small differences if the initial concentrations are very small.

$\mathrm{SC}$ was used as a surrogate for dissolved solids and major ions. SC of point samples also tended to be larger than the SC in the associated EWI samples for each station; point-sample values were larger than the associated EWI sample values in 16 of 18 sample pairs. Similar to differences in dissolved selenium concentrations, the range in the absolute values of the differences between the SC of the EWI sample and the SC of the point sample generally were small. RPDs of specific conductance between EWI and point samples were greater than 5 percent in 4 of 18 sample pairs.

The Mann-Whitney test (Helsel and Hirsch, 2002) was used to evaluate the significance of perceived differences in the dissolved selenium concentration and specific conductance between the EWI and point samples. The p-value, for differences between median dissolved selenium concentrations, 0.5690, and specific conductance, 0.5583, in EWI and point samples were greater than the $\alpha$ value of 0.05 . Therefore, there are no statistically significant differences between the concentrations of dissolved selenium or specific conductance values of the EWI and point samples.

The general tendency for point-sample concentrations to be greater than EWI sample concentrations suggests a small positive bias in dissolved selenium concentration and SC in point samples. The small range of differences in dissolved selenium concentration and SC between EWI and point samples, however, indicates that the stream generally was well mixed relative to the collection locations of the point sample and the EWI sample on the days sampled. Therefore, the point samples collected by automated pumping samplers are considered to adequately represent the chemistry of the stream, and the use of automated pumping samplers is not considered to have introduced substantial bias into the data set.

\section{Characteristics of Streamflow, Water Quality, and Instantaneous Dissolved Solids, Selenium, and Uranium Loads in the Arkansas River Basin from Canon City to Near Portland}

Water quality in the reach from Canon City to near Portland (UARB) is influenced by natural and anthropogenic factors associated with land- and water-use practices. Streamflow was measured at both long-term and at study-specific temporary gages for use in water-quality analysis and computing instantaneous loads. Data for periodic as well as synoptic water-quality samples were used to assess water quality and instantaneous loads of dissolved solids, selenium, and uranium.

\section{Streamflow Characteristics}

In the UARB, long-term (pre-2000) streamflow data are available for two stations-Ark at Canon City and Ark at Portland. These stations are operated and the data administered by the CODWR (Colorado Division of Water Resources, 2011). Temporary streamflow gages were installed at the Ark nr Canon City and Ark nr Portland stations for this study, and streamflow records were collected for 2009-2010.

Streamflow data for 2009-2010 from both long-term Arkansas River stations were compared to data for 1990-2008 (fig. 5). To increase the number of observations and the power of statistical tests in this study, streamflow data beginning in 1990 were included in selected data sets. Summary statistics for streamflow for stations and time periods are shown in table 8. The 2009-2010 hydrographs for the sites at Ark at Canon City and Ark at Portland are similar to hydrographs for those same stations for previous years, with the exception of years 1995 and 2002. The high flows in 1995 and the low flows in 2002 account for the differences in the maximum and minimum flows between the historical record and the 2009-2010 study period (fig. 5). However, for each of the two stations, the median and mean flows for the two periods are similar.

Seasonal hydrographs for 2009-2010 (fig. 6) are available for five tributary stations-Fourmile Cr, Brush Hollow, Hardscrabble Cr, Bear Cr, and Beaver Cr (fig. 2) - whereas only instantaneous flow data are available for other tributary stations and diversion sites in the study reach. Median flows for these five tributaries ranged from a low of $0.76 \mathrm{ft}^{3} / \mathrm{s}$ in Beaver $\mathrm{Cr}$ to a high of $24 \mathrm{ft}^{3} / \mathrm{s}$ in Fourmile Cr. The smallest minimum, $0.01 \mathrm{ft}^{3} / \mathrm{s}$, was measured in Hardscrabble $\mathrm{Cr}$; the largest maximum, $150 \mathrm{ft}^{3} / \mathrm{s}$, was measured in Fourmile Cr. Of the seasonally measured tributaries, Fourmile $\mathrm{Cr}$ had the largest flow.

\section{Water-Quality Characteristics}

Water samples for main-stem and tributary sites were analyzed for selected constituents to characterize the water quality in the UARB and to identify potential source areas for dissolved solids, selenium, and uranium loads. Constituents sampled include specific conductance, major ions, dissolved solids, nutrients, select dissolved trace elements (selenium and uranium), and hydrogen and oxygen isotopes. Larger scale Arkansas River Basin water-quality studies (Dash and Ortiz, 1996; Ortiz and others, 1998) began in the 1990s; previous to this, studies were generally limited in scope and scale. To increase the number of observations and the power of 
$\boldsymbol{A}$

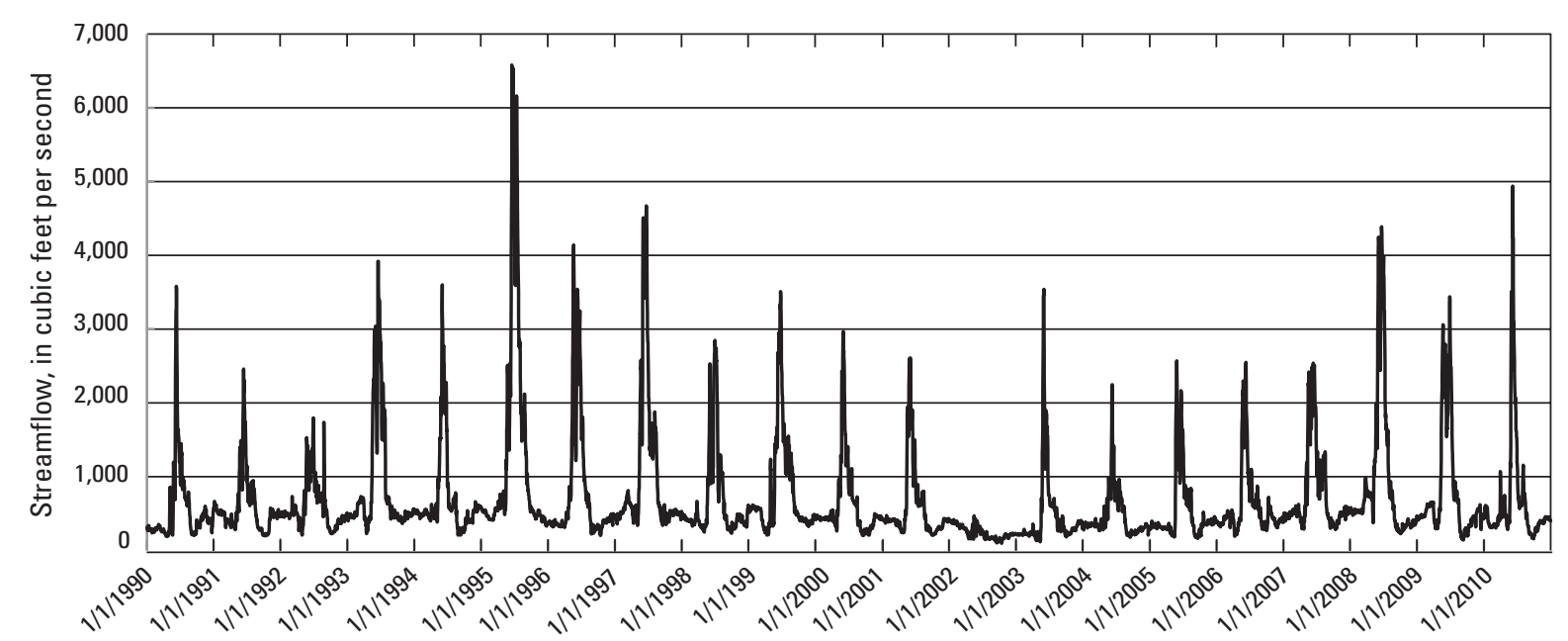

B

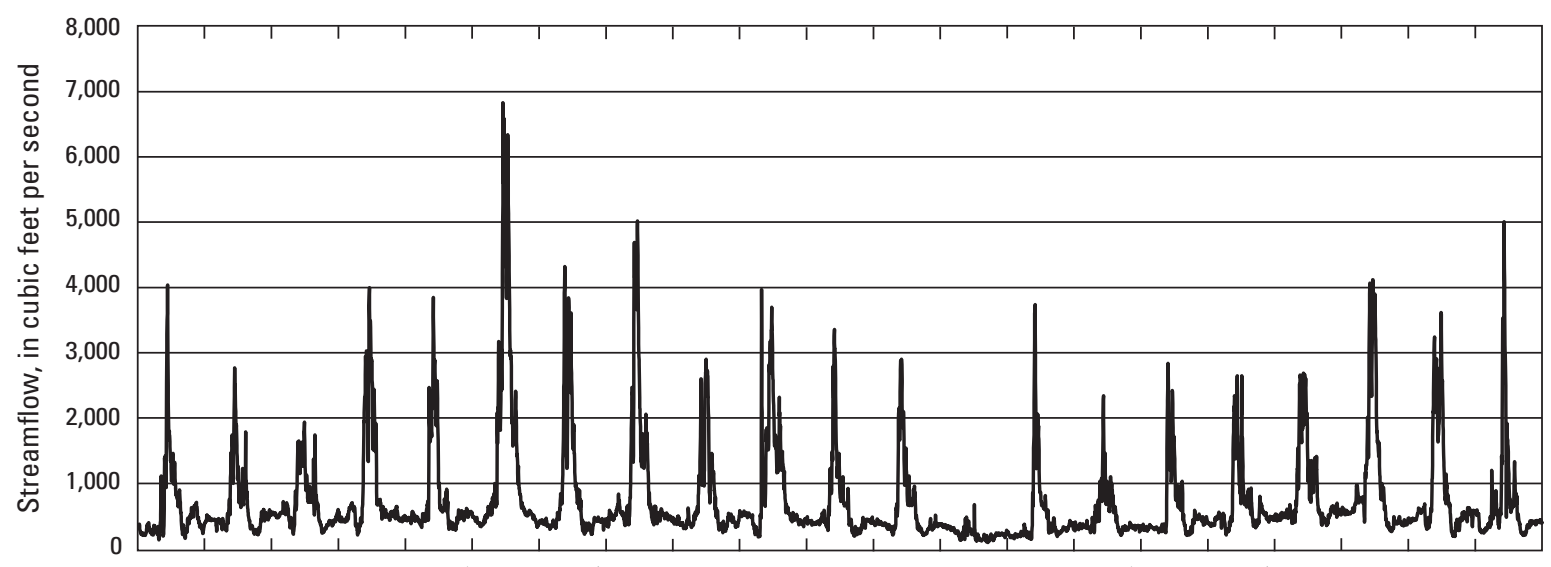

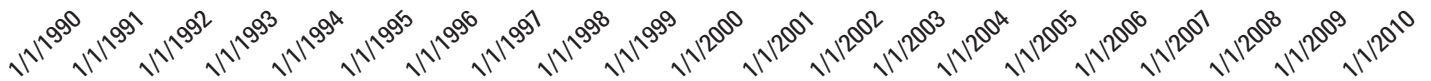

Figure 5. Streamflow hydrographs for (A) Arkansas River at Canon City and (B) Arkansas River at Portland on the Arkansas River, 1990-2010.

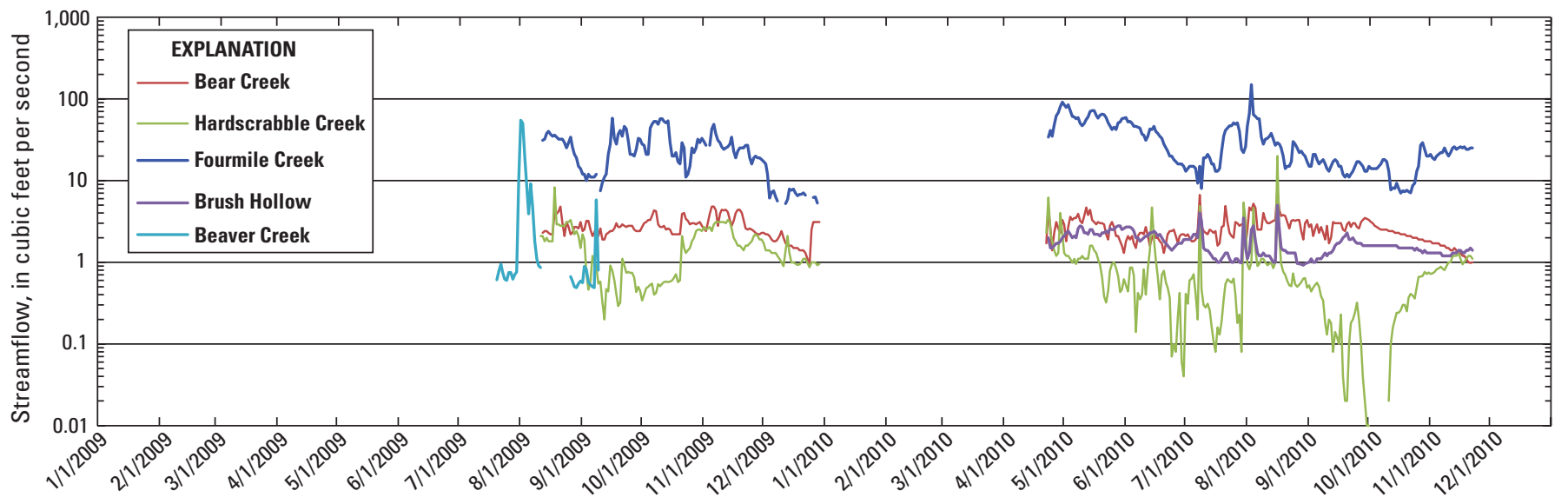

Figure 6. Seasonal streamflow hydrographs for Beaver Creek, Bear Creek, Brush Hollow, Fourmile Creek, and Hardscrabble Creek, Upper Arkansas River Basin, 2009-2010. 
Table 8. Summary statistics for Arkansas River streamflow data 1990-2008 and 2009-2010 for Arkansas River at Canon City and Arkansas River at Portland gage stations.

Complete site name given in table $1 ; \mathrm{ft}^{3} / \mathrm{s}$, cubic feet per second]

\begin{tabular}{|c|c|c|c|c|c|c|c|c|}
\hline \multirow{2}{*}{ Site name } & \multicolumn{2}{|c|}{ Maximum flow, $\mathrm{ft}^{3} / \mathrm{s}$} & \multicolumn{2}{|c|}{ Minimum flow, $\mathrm{ft}^{3} / \mathrm{s}$} & \multicolumn{2}{|c|}{ Median flow, $\mathrm{ft}^{3} / \mathrm{s}$} & \multicolumn{2}{|c|}{ Mean flow, $\mathrm{ft}^{3} / \mathrm{s}$} \\
\hline & 1990-2008 & 2009-2010 & 1990-2008 & 2009-2010 & 1990-2008 & 2009-2010 & 1990-2008 & 2009-2010 \\
\hline Ark at Canon City & 6,580 & 4,940 & 98 & 144 & 451 & 457 & 686 & 728 \\
\hline
\end{tabular}

statistical tests in this study, water-quality data from Dash and Ortiz (1996) and Ortiz and others (1998) beginning in 1990 were included in selected data sets.

\section{Specific Conductance}

Specific conductance (SC) values within the UARB varied spatially and temporally. SC values increased downstream from Ark at Canon City to Ark at Portland during 2009-2010, but the magnitude of the downstream increases between sites was variable (fig. 7). The lowest SC values (for all four sites) occurred in late May to early June during periods of high flow in both 2009 and 2010, whereas the highest values occurred in September during periods of low flow. When the flow in the river was dominated by snowmelt runoff during May and June, SC values varied little and the magnitude of the downstream increases between sites was small. During periods of low flow (base flow) in September, when local inflows, such as groundwater inflow and (or) irrigation return flow represent a greater portion of the total flow as compared to periods of high flows from snowmelt, SC values were higher and the downstream increases in $\mathrm{SC}$ values were larger between sites (fig. 7). Groundwater, recharged largely by irrigation water enriched in dissolved solids, discharging to the Arkansas River under low-flow conditions, may be providing a concentrated source of dissolved constituents, thereby increasing the $\mathrm{SC}$ in September.

\section{Major lons}

Water from main-stem sites beginning at Canon City are a calcium-magnesium-bicarbonate water type and transition downstream to a calcium-magnesium-sulfate water type at the Ark nr Portland site (fig. 8). A previous study by Ortiz and others (1998) reported calcium and bicarbonate as dominant ions in samples from main-stem Arkansas River site, but that study did not include the Ark nr Portland site. Changes in water type are likely due to changes in geology (fig. 9) from igneous and metamorphic to sedimentary bedrock and the changes in the chemical composition of the various bedrocks (Crouch and others, 1984).

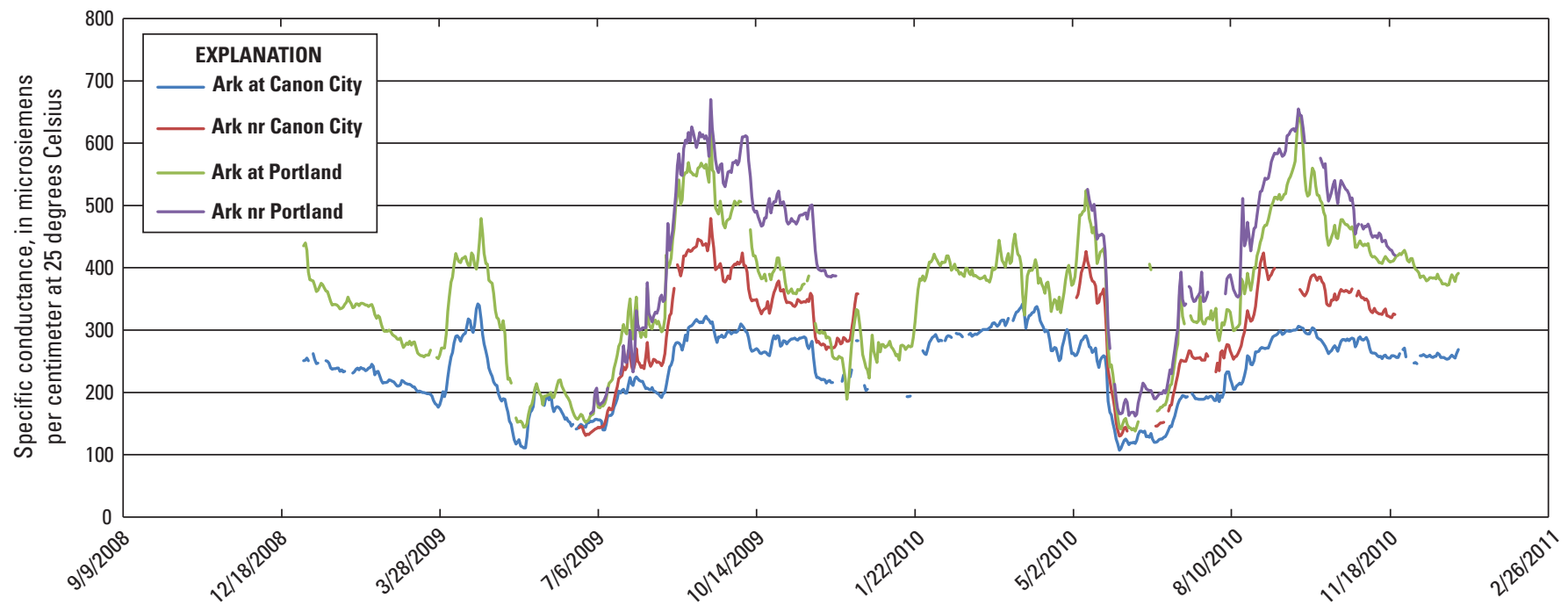

Figure 7. Continuous specific conductance values at main-stem sites in the Upper Arkansas River Basin from Canon City to near Portland, 2009-2010. 


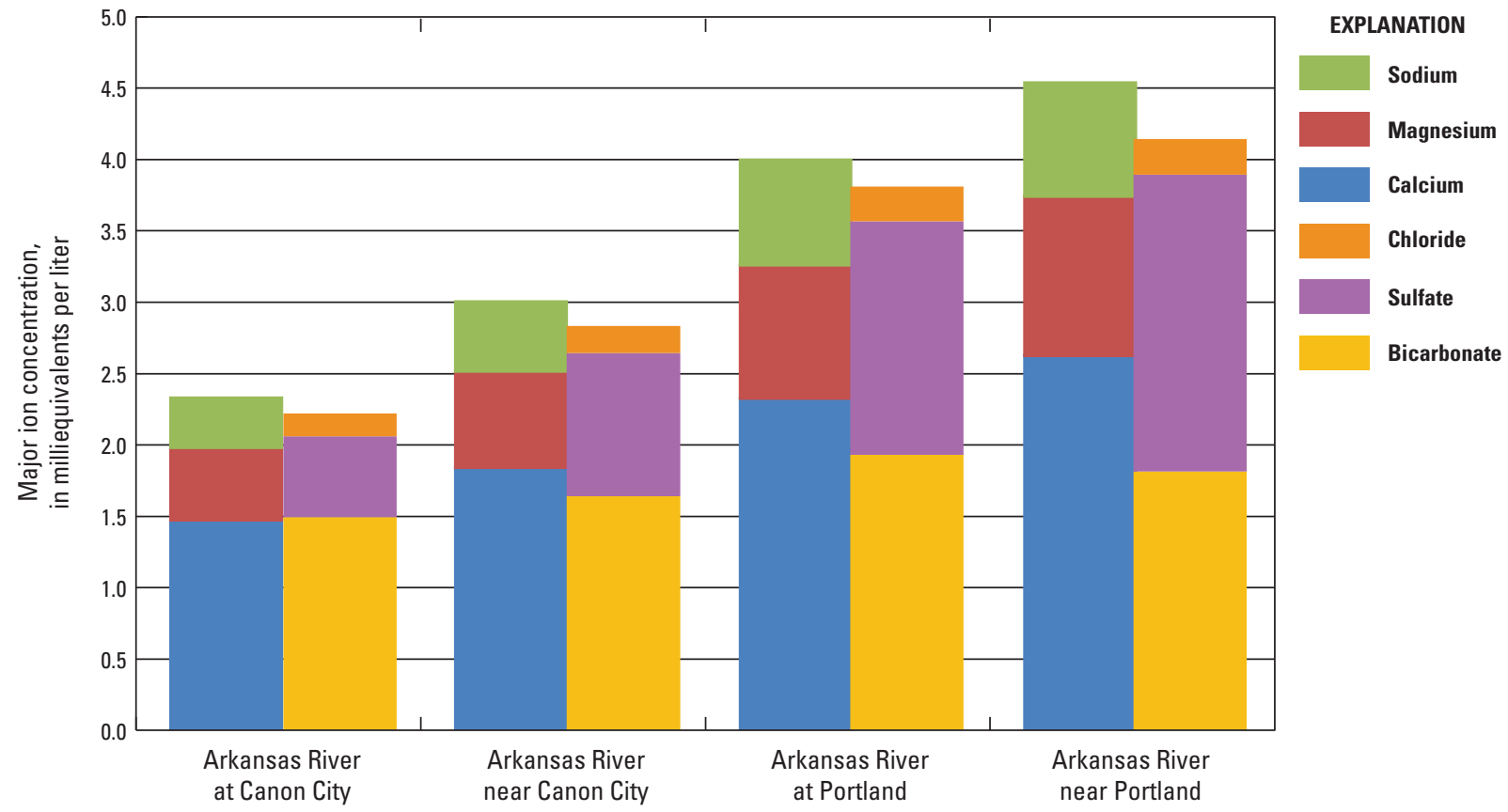

Figure 8. Comparison of median concentrations of six major ions in the Arkansas River, from Canon City to near Portland, 2009-2010.

\section{Dissolved Solids}

Main-stem DS (salinity) median concentrations, as previously reported by Dash and Ortiz (1996), Ortiz and others (1998), and Miller and others (2010), increase (fig. 10) downstream from the Ark at Canon City site $(153 \mathrm{mg} / \mathrm{L})$ to the Ark near Portland site $(264 \mathrm{mg} / \mathrm{L})$. Median DS concentrations in tributaries and the Rainbow Park WWTP outflow varied and ranged from a low of $213 \mathrm{mg} / \mathrm{L}$ in Oak $\mathrm{Cr}$ to a high of $6,305 \mathrm{mg} / \mathrm{L}$ in water sampled from Ark trib 1 at CR 112. Miller and others (2010) reported higher DS concentrations in areas of the Arkansas River Basin is likely due to the use, return, and reuse of irrigation water and potential irrigation water recharge of local unconfined aquifers. Inflows from irrigation recharged groundwater may contribute to the high DS concentrations in the UARB tributaries, especially those tributaries below Ark trib 2 at CR 119 near Florence, Colo., and those that drain the Penrose, Colo., area where hay, pasture, orchard and cropland acres are irrigated (fig. 9). As with SC, the higher DS concentrations downstream from Florence can also be attributed to variations in geology (Miller and others, 2010) and the chemical composition of the bedrock.

In natural waters, SC is a good estimator of DS concentrations (Hem, 1985). To determine the relation, DS concentrations in the main-stem Arkansas River and selected tributaries were analyzed and statistically compared to SC. Table 9 lists results of the linear regression analysis of water samples from individual sites. Many of the sites, both main stem and tributary, even with a small number of samples $(<10)$, indicate a statistically significant relation between DS and SC $\left(\mathrm{r}^{2}>0.92\right)$. However, four tributaries downstream from Brush Hollow have DS and SC concentrations that are less correlated ( $\mathrm{r}^{2}$ values ranging from 0.039 to 0.740 ; table 9 ). Small data sets and outliers may be the cause of the less statistically significant relations between DS concentrations and SC in these tributaries. Ranger $\mathrm{Cr}$, as an example, with $\mathrm{r}^{2}=0.039$ (the lowest $\mathrm{r}^{2}$ for the tributary samples), has two outlier samples in a small $(\mathrm{n}=7)$ data set producing a regression with a weak correlation. Additional samples from a variety of streamflow regimes may improve the DS and SC relation for this Arkansas River tributary.

Based on DS concentrations and instantaneous streamflow values for samples collected during 2009-2010, the natural logarithm $(\log )$ of the DS concentration can be reasonably predicted from the natural log of streamflow $\left(r^{2}=0.64 ; p\right.$-value $\left.<0.00001\right)$ for all three main-stem sites (fig. 11A). Tributary sites had fewer samples collected, and for the 2009-2010 data set, the correlation $\left(r^{2}=0.11\right)$ between the natural $\log$ of DS concentration and natural log of streamflow was weak (fig. 11B). Continued collection of paired DS and streamflow data, under a variety of flow regimes, might be used to build a statistical relation for each tributary, so that continuously monitored streamflow can be used to estimate DS for all seasonal streamflow conditions instead of collecting and analyzing several water-quality samples for DS. 


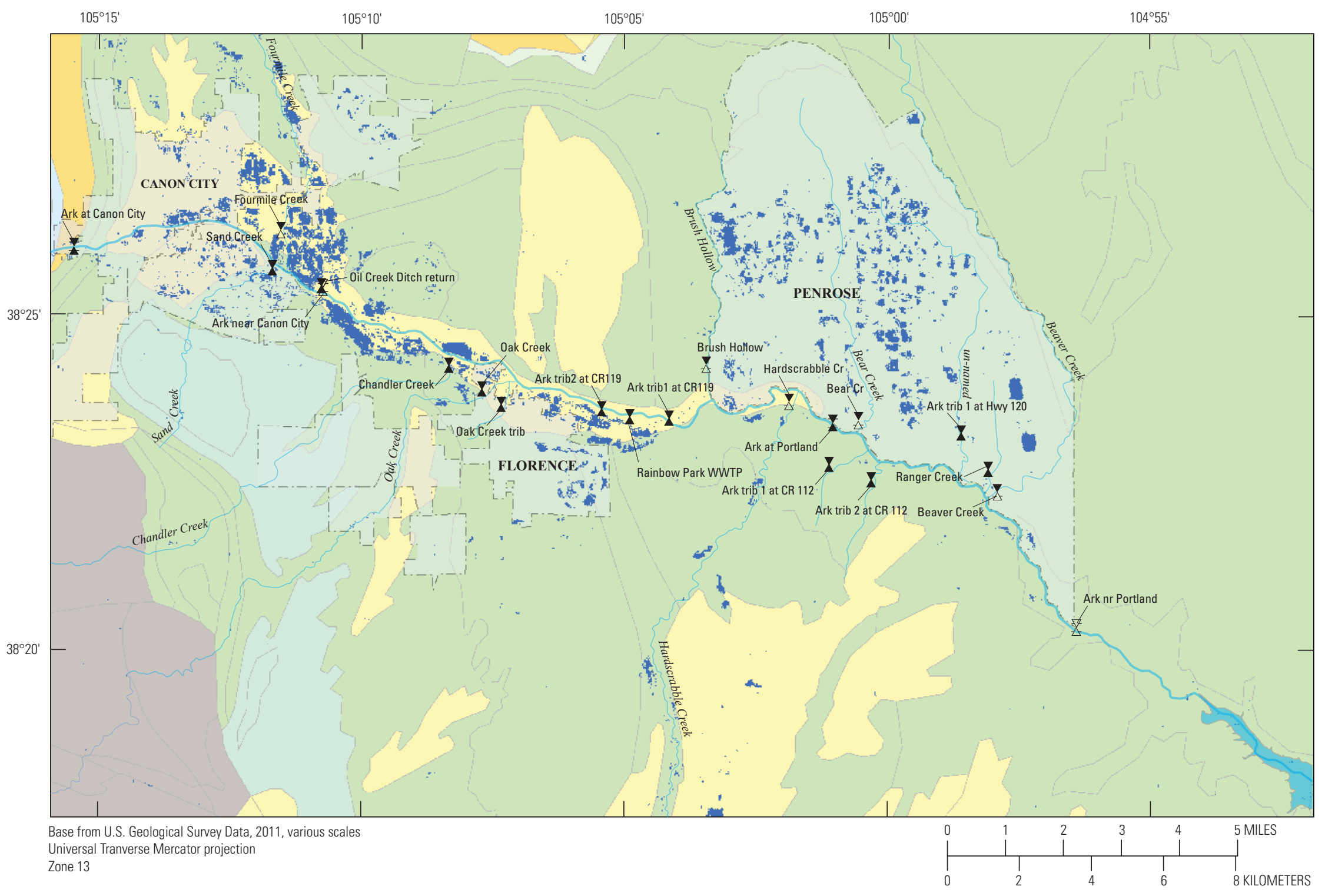

Figure 9. Generalized geology and 2010 irrigated cropland in the Upper Arkansas River Basin, from Canon City to near Portland. 


\section{EXPLANATION}

\begin{tabular}{|c|c|}
\hline & $\begin{array}{l}\text { Towns } \\
\text { Geology }\end{array}$ \\
\hline & Quaternary alluvial deposits \\
\hline & Sedimentary rocks of Cretaceous age \\
\hline & Sedimentary rocks of Jurassic age \\
\hline & Sedimentary rocks of Triassic age \\
\hline & Sedimentary rocks of Permian age \\
\hline & Crystalline rocks of Precambrian age \\
\hline & Geology modified from Green (1992) \\
\hline $\mathbf{X}$ & $\begin{array}{l}\text { Ranger Creek } \\
\text { Periodic streamflow and periodic water-quality site and site name }\end{array}$ \\
\hline$\nexists$ & $\begin{array}{l}\text { Brush Hollow } \\
\text { Seasonal continuous streamflow and periodic water-quality site and site name }\end{array}$ \\
\hline $\bar{x}$ & $\begin{array}{l}\text { Ark at Canon City } \\
\text { Long-term continuous streamflow and periodic water-quality site with long-term } \\
\text { water-quality monitoring and site name }\end{array}$ \\
\hline 7 & $\begin{array}{l}\text { Ark near Portland } \\
\text { Seasonal continuous streamflow and periodic water-quality site with seasonal } \\
\text { water-quality monitoring and site name }\end{array}$ \\
\hline & $\begin{array}{l}2010 \text { irrigated cropland } \\
\text { Irrigated cropland modified from } \\
\text { U.S. Department of Agriculture (2011) }\end{array}$ \\
\hline
\end{tabular}

\section{Nutrients}

As part of this study, dissolved nutrient samples were only collected from the Ark at Portland and Ark nr Portland main-stem sites during 2009-2010. In addition to concentrations for these samples, nutrient concentrations of samples collected since 1990 from main-stem sites as part of previous investigations were included in this analysis. Nutrient concentrations for samples collected from three main-stem Arkansas River sites during 1990-2010 indicate a downstream increase in median total phosphorus concentrations from $0.03 \mathrm{mg} / \mathrm{L}$ at Ark at Portland to $0.08 \mathrm{mg} / \mathrm{L} \mathrm{nr}$ Portland. Median concentration of dissolved nitrite-plus-nitrate increased from $0.05 \mathrm{mg} / \mathrm{L}$ at Ark at Canon City to $0.17 \mathrm{mg} / \mathrm{L}$ at Ark at Portland and decreased slightly to $0.16 \mathrm{mg} / \mathrm{L}$ at Ark nr Portland (fig. 12). Concentrations of nitrite-plus-nitrate do not exceed the USEPA drinking water standard (10 mg/L as N) (U.S. Environmental Protection Agency, 2011), and no drinking-water standards have been established for total phosphorus.

\section{Trace Elements}

Concentrations of dissolved selenium and dissolved uranium were analyzed in samples collected from main-stem and selected tributary sites during 2009-2010. Main-stem sites were sampled more frequently for trace elements than the tributary sites (table 3). Boxplots (fig. 13) of selenium and uranium concentrations in water samples collected from the Arkansas River sites indicate that concentrations increase downstream from Canon City to near Portland. Median dissolved selenium concentrations increased downstream from 0.17 micrograms per liter $(\mu \mathrm{g} / \mathrm{L})$ at Ark at Canon City to $0.43 \mu \mathrm{g} / \mathrm{L}$ at Ark nr Canon City to $0.69 \mu \mathrm{g} / \mathrm{L}$ at Ark at Portland and $1.10 \mu \mathrm{g} / \mathrm{L}$ at Ark nr Portland. Median dissolved uranium concentrations increased downstream from $2.57 \mu \mathrm{g} / \mathrm{L}$ Ark at Canon City to $3.20 \mu \mathrm{g} / \mathrm{L}$ at Ark nr Canon City to $4.38 \mu \mathrm{g} / \mathrm{L}$ at Ark at Portland and $4.76 \mu \mathrm{g} / \mathrm{L}$ at Ark nr Portland. Concentrations of dissolved selenium and dissolved uranium in water samples collected from the Arkansas River in the UARB did not exceed USEPA drinking water standards of $50 \mu \mathrm{g} / \mathrm{L}$ and $30 \mu \mathrm{g} / \mathrm{L}$, respectively (U.S. Environmental Protection Agency, 2011).

The concentrations of dissolved selenium in water samples collected from Arkansas River tributaries generally were less than the USEPA drinking-water standard of $50 \mu \mathrm{g} / \mathrm{L}$. However, the concentration of dissolved selenium in one sample collected in Bear $\mathrm{Cr}(66 \mu \mathrm{g} / \mathrm{L})$ exceeded the USEPA drinking-water standard of $50 \mu \mathrm{g} / \mathrm{L}$. Concentrations of dissolved uranium in water samples from the Arkansas River tributary sites of Brush Hollow (34 $\mu \mathrm{g} / \mathrm{L})$, Hardscrabble Cr $(30 \mu \mathrm{g} / \mathrm{L})$, Bear Cr $(36 \mu \mathrm{g} / \mathrm{L}$ and $37 \mu \mathrm{g} / \mathrm{L})$, and Ranger 


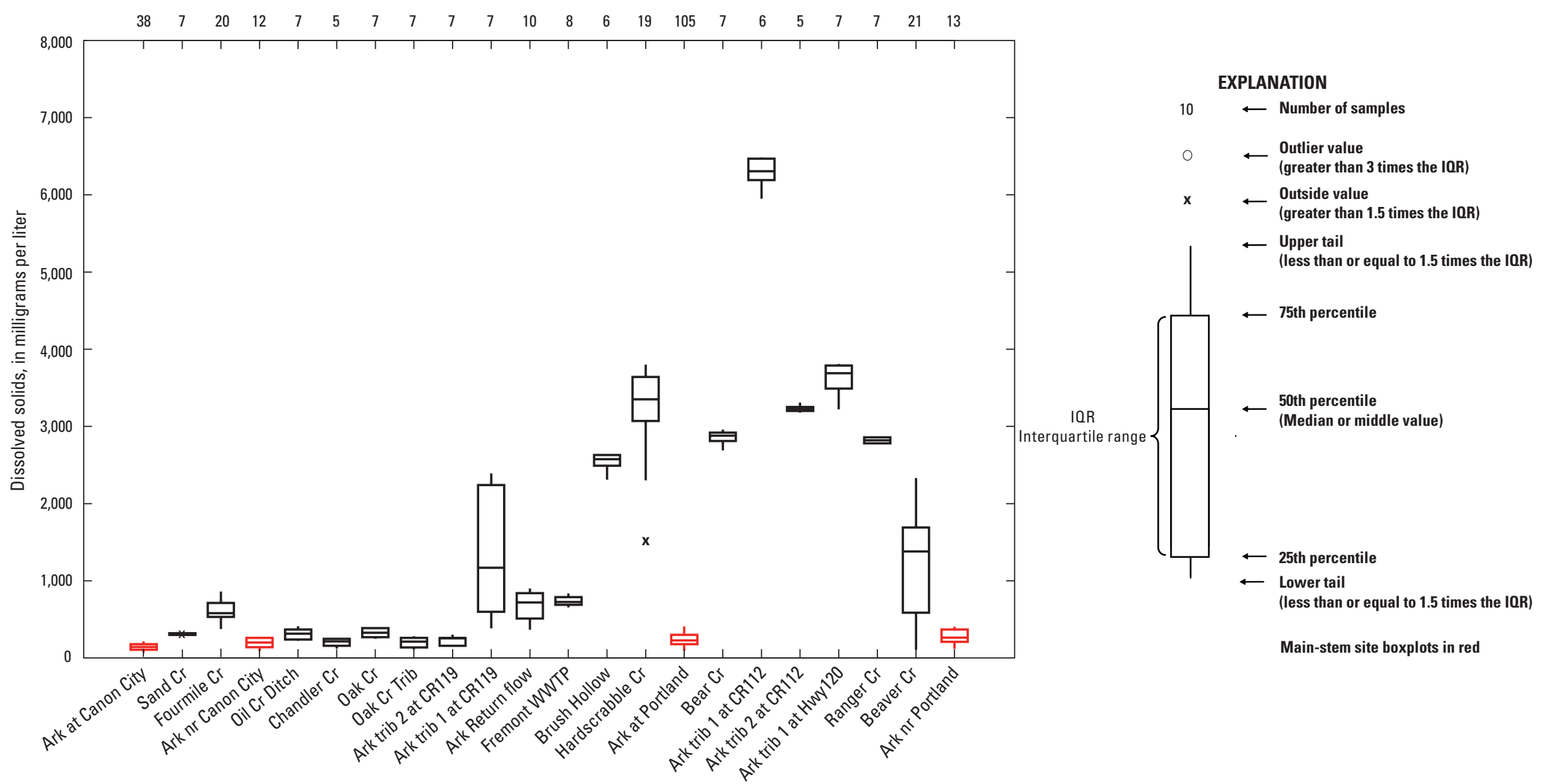

Figure 10. Comparison of dissolved-solids in the Arkansas River and selected tributaries from Canon City to near Portland, 1990-2010. 
Table 9. Regression equations relating dissolved-solids concentration and specific conductance in the Upper Arkansas River and selected tributaries from Canon City to near Portland, 2009-2010.

[Complete site names given in table 1; DS, dissolved solids, in milligrams per liter; SC, specific conductance, in microsiemens per centimeter at 25 degrees Celsius; $\mathrm{r}^{2}$, coefficient of determination]

\begin{tabular}{|c|c|c|c|}
\hline Site name & Equation & $\begin{array}{c}\text { Number of } \\
\text { comparisons }\end{array}$ & $\mathbf{r}^{2}$ \\
\hline Ark at Canon City & $\mathrm{DS}=0.607 \mathrm{SC}+1.371$ & 13 & .970 \\
\hline Sand $\mathrm{Cr}$ & $\mathrm{DS}=0.67 \mathrm{SC}-33.3$ & 7 & .923 \\
\hline Fourmile $\mathrm{Cr}$ & $\mathrm{DS}=0.751 \mathrm{SC}-51.7$ & 7 & .956 \\
\hline Ark nr Canon City & $\mathrm{DS}=0.636 \mathrm{SC}-0.765$ & 13 & .981 \\
\hline Oil Cr Ditch return & $\mathrm{DS}=0.687 \mathrm{SC}-11.4$ & 7 & .976 \\
\hline Chandler Cr & $\mathrm{DS}=0.575 \mathrm{SC}+11.5$ & 5 & .975 \\
\hline Oak Cr & $\mathrm{DS}=0.618 \mathrm{SC}+4.39$ & 7 & .988 \\
\hline Oak $\mathrm{Cr}$ trib & $\mathrm{DS}=0.592 \mathrm{SC}+9.61$ & 7 & .991 \\
\hline Ark trib 2 at CR 119 & $\mathrm{DS}=0.637 \mathrm{SC}-2.83$ & 7 & .977 \\
\hline Ark trib 1 at CR 119 & $\mathrm{DS}=0.934 \mathrm{SC}-223.9$ & 7 & .997 \\
\hline Ark rtn at Hwy 115 & $\mathrm{DS}=0.778 \mathrm{SC}-75.4$ & 9 & .999 \\
\hline Brush Hollow & $\mathrm{DS}=1.02 \mathrm{SC}-377.7$ & 7 & .897 \\
\hline Hardscrabble $\mathrm{Cr}$ & $\mathrm{DS}=1.11 \mathrm{SC}-479.4$ & 6 & .995 \\
\hline Ark at Portland & $\mathrm{DS}=0.637 \mathrm{SC}+1.06$ & 21 & .983 \\
\hline Bear Cr & $\mathrm{DS}=0.807 \mathrm{SC}+485.7$ & 7 & .465 \\
\hline Ark trib 1 at CR 112 & $\mathrm{DS}=1.50 \mathrm{SC}-2758.7$ & 7 & .586 \\
\hline Ark trib 2 at CR 112 & $\mathrm{DS}=0.540 \mathrm{SC}+1470$ & 6 & .740 \\
\hline Ark trib1 at Hwy 120 & $\mathrm{DS}=1.37 \mathrm{SC}-1129.4$ & 7 & .964 \\
\hline Ranger $\mathrm{Cr}$ & $\mathrm{DS}=0.665 \mathrm{SC}+913.1$ & 7 & .039 \\
\hline Beaver Cr & $\mathrm{DS}=1.02 \mathrm{SC}-230.4$ & 7 & .993 \\
\hline Ark nr Portland & $\mathrm{DS}=0.667 \mathrm{SC}-10.4$ & 13 & .988 \\
\hline
\end{tabular}

$\mathrm{Cr}(47 \mu \mathrm{g} / \mathrm{L})$, equaled or exceeded USEPA drinking-water standard $(30 \mu \mathrm{g} / \mathrm{L})$ (U.S. Environmental Protection Agency, 2011). All samples with exceedences were collected in the summer and fall, when flows in these tributaries were low.

Regression analysis of dissolved selenium and uranium concentrations in samples from the three main-stem sites indicate that concentrations of these trace elements can be reasonably predicted from DS, SC, and streamflow. Based on data for 1990-2010, selenium in the main-stem samples from Canon City to near Portland is correlated with SC $\left(r^{2}=0.79\right)$ and DS $\left(r^{2}=0.81\right)$ (fig. 14A); however, uranium concentrations in the main-stem samples are significantly correlated with SC $\left(\mathrm{r}^{2}=.94\right)$ and DS $\left(\mathrm{r}^{2}=.93\right)$ (fig. 14B). Whittmore and others (2010) and Snow and Spalding (1994) reported similar uranium-SC and uranium-DS correlations in the Arkansas and Platte Rivers, respectively. The significant correlation of dissolved uranium with both SC and DS in samples from the Arkansas River Basin is a result of sulfate mineral dissolution and clay mineral ion-exchange reactions in the weathered shale bedrock and shaley soils (Zielinski and others, 1995). The statistically significant correlation of uranium (and less so for selenium) with SC could allow for good estimates of uranium (and possibly selenium) concentrations and loads in the Arkansas River at gaging stations with continuous specificconductance monitors (Whittmore and others, 2010).

Dissolved selenium and uranium concentrations in samples from main-stem Arkansas River sites during 20092010 decreased with increasing streamflow (fig. 15); however, uranium concentrations have a stronger correlation $\left(\mathrm{r}^{2}=0.75\right)$ with streamflow than does selenium $\left(r^{2}=0.28\right)$. The seleniumstreamflow and uranium-streamflow relations may indicate that groundwater contributes more of these constituents to the Arkansas River than surface-water runoff or tributaries at low streamflows. At higher streamflows (greater than $500 \mathrm{ft}^{3} / \mathrm{s}$; fig. 15), surface-water flow may dilute dissolved selenium and uranium concentrations in groundwater discharge and (or) impede groundwater containing dissolved selenium and uranium from discharging to the Arkansas River. 

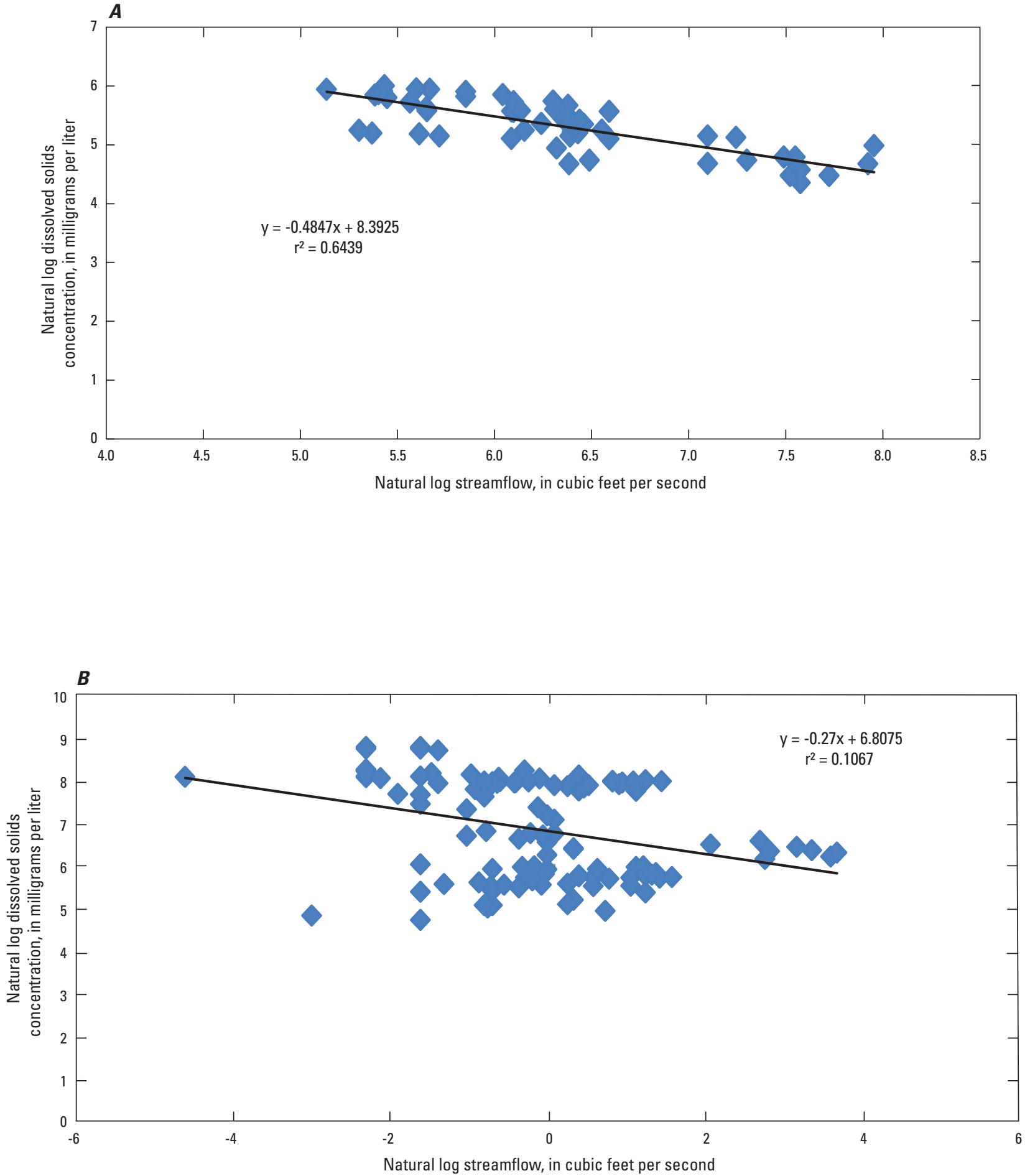

Figure 11. Relation between dissolved-solids concentration and streamflow in the $(A)$ Arkansas River and $(B)$ selected tributaries from Canon City to near Portland, 2009-2010. 


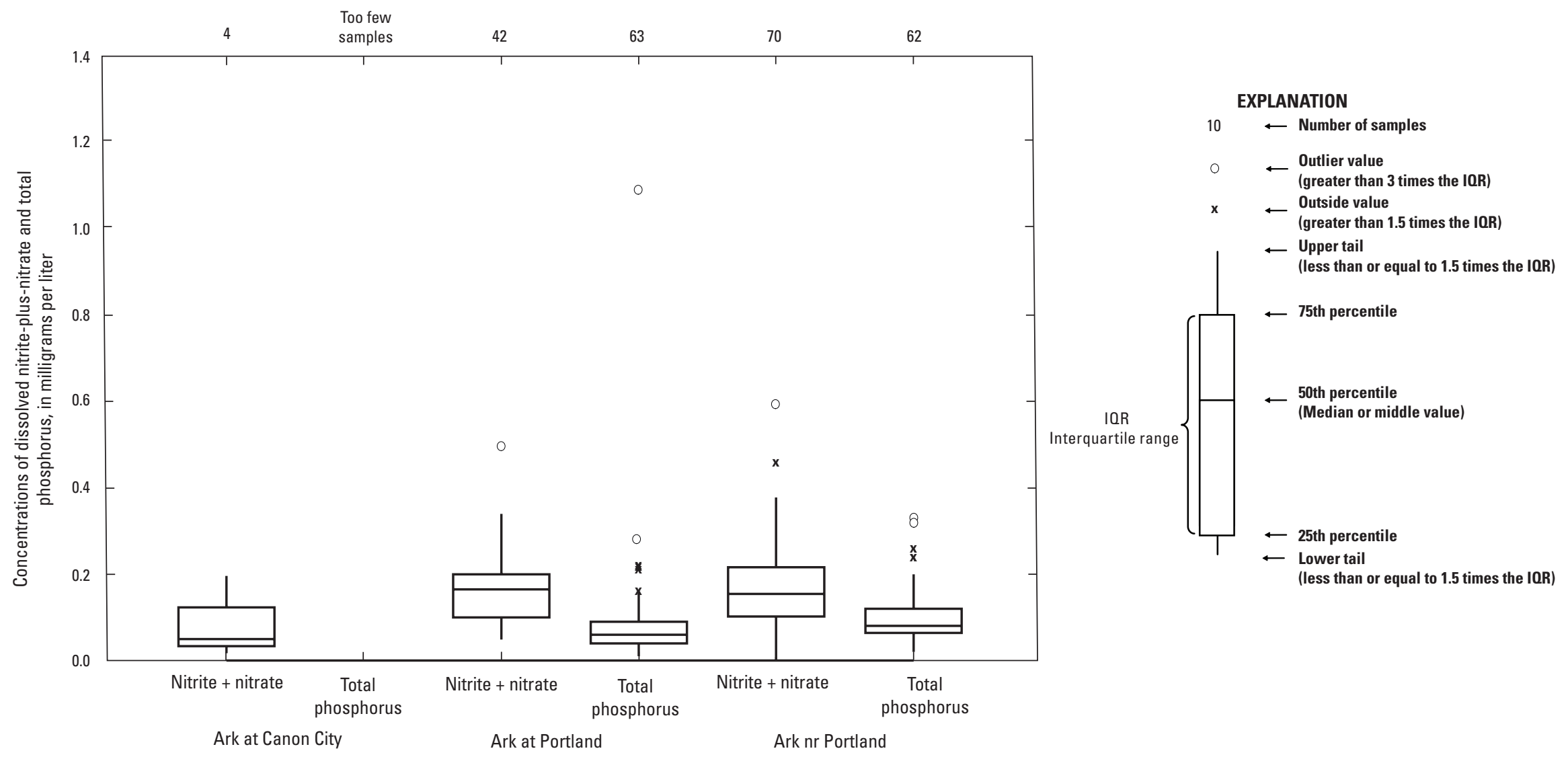

Figure 12. Comparison of concentrations of dissolved nitrite-plus-nitrate and total phosphorus in the Arkansas River from Canon City to near Portland, $1990-2010$. 

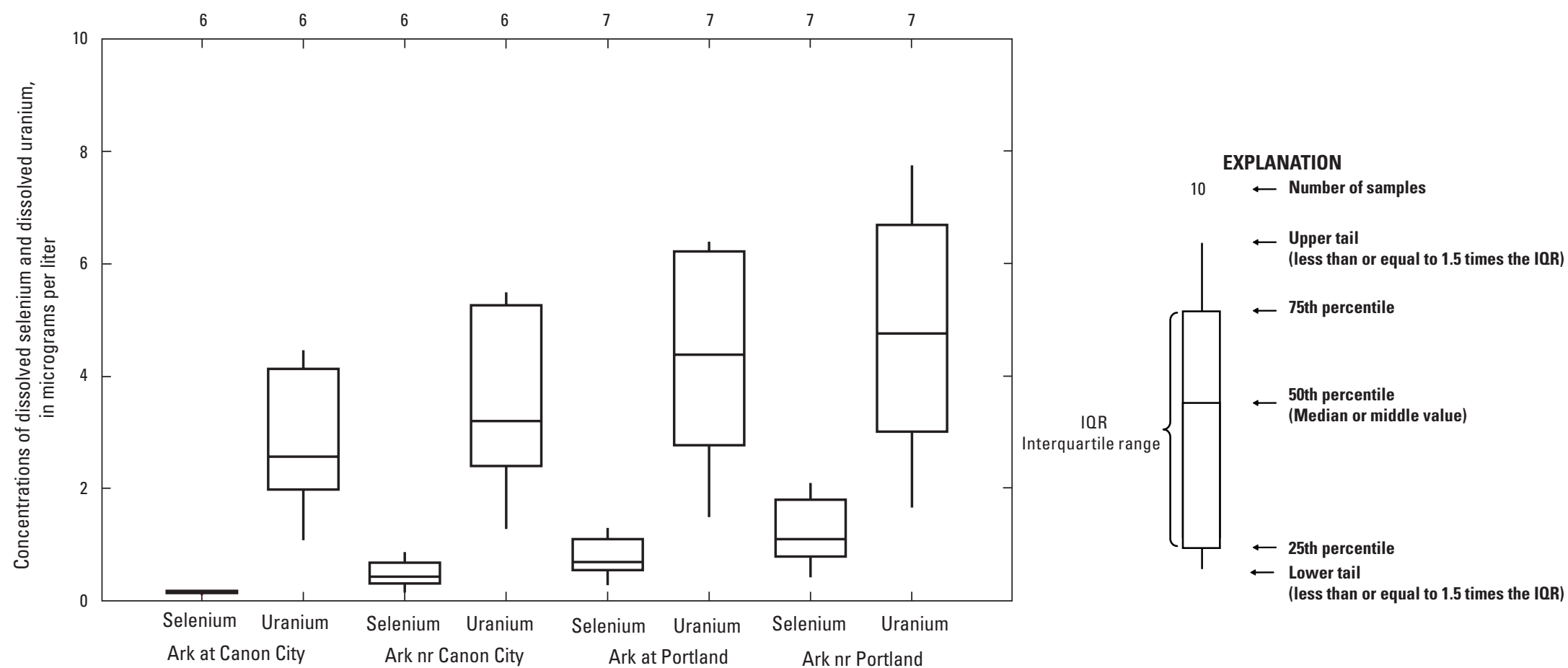

Figure 13. Comparison of concentrations of dissolved selenium and dissolved uranium in the Arkansas River from Canon City to near Portland, $2009-2010$. 


\section{Hydrogen and Oxygen Isotopes}

The isotopic compositions of hydrogen and oxygen in the water molecules of surface water from main-stem Arkansas River and tributary sites were analyzed to determine potential sources of water and the effects of evaporation. Isotopes are atoms of the same element that differ in mass because of a difference in the number of neutrons in the nucleus. As an example, ${ }^{2} \mathrm{H}$ (deuterium, commonly shown as D) is hydrogen with one proton and one neutron in the atom nucleus, whereas ${ }^{1} \mathrm{H}$ has only one proton and no neutron in the nucleus. Isotopic fractionation is the partitioning of isotopes by either physical or chemical processes and is proportional to their masses, and because of the intimate association with water, isotopic fractionation of hydrogen and oxygen are usually covariant, and any change will be in the same direction and magnitude (Coplen, 1993).

Isotopic compositions of the stable isotopes $\mathrm{D}$ and ${ }^{18} \mathrm{O}$ are expressed as a ratio of ${ }^{2} \mathrm{H}$ to ${ }^{1} \mathrm{H}$ and ${ }^{18} \mathrm{O}$ to ${ }^{16} \mathrm{O}$ and are reported as the delta $(\delta)$ value of the heavier isotope (for example, $\delta^{18} \mathrm{O}$ because it is heavier than $\left.{ }^{16} \mathrm{O}\right)$ in units of per mil $(1 / 1,000)$ with respect to a standard. For example, a water sample with a $\delta^{18} \mathrm{O}$ value of +25.0 per mil is enriched in ${ }^{18} \mathrm{O}$ by 25.0 per mil relative to the standard and is isotopically "heavy" relative to the standard. A negative delta value indicates that the sample is depleted in the heavy isotope relative to the standard; therefore, the sample is isotopically "light" in relation to the standard (Coplen, 1993). Oxygen and hydrogen isotopes in water samples are reported relative to the Vienna Standard Mean Ocean Water (VSMOW).

The relation between $\delta \mathrm{D}$ and $\delta^{18} \mathrm{O}$ in precipitation varies along a global meteoric water line (GMWL) with the equation

$$
\delta \mathrm{D}=8 \delta^{18} \mathrm{O}+\mathrm{d}
$$

where $d$ is the deuterium excess parameter. Craig (1961) found the global mean value of $d$ for freshwater sources to be +10 per mil. However, factors such as temperature and humidity can affect the value of $\mathrm{d}$, and factors such as humidity, temperature, and salt concentration can affect the slope (here represented by the value of 8 in equation 2). Evaporation from surface-water bodies can enrich $\delta \mathrm{D}$ and $\delta^{18} \mathrm{O}$ in water causing a reduction in slope to values less than 8 , usually ranging between 3 and 6 (Coplen, 1993).

The $\delta \mathrm{D}$ and $\delta^{18} \mathrm{O}$ for main-stem and tributary samples (fig. 16) for the Arkansas River plot along a linear trend; however, most samples plot below the GMWL and are similar to the local meteoric water line (LMWL) for Colorado (Kendall and Coplen, 2001). The LMWL is derived from isotope samples collected for a specific location, and the slope of the line ( 6.3 for Colorado) for those samples will vary with humidity, which imparts a distinctive evaporative signature to precipitation (Kendall and Coplen, 2001). Arkansas River main-stem and some tributary samples plot into three groups (fig. 16) showing temporal variability. The first group (A) consists of main-stem samples and tributary samples for
Chandler Cr, Oak Cr, and Lake Cr collected in May 2010 and are the most isotopically light, suggesting that the water has not been affected by evaporation. Lake $\mathrm{Cr}$ near the headwaters of the Arkansas River was sampled to represent a background site for snowmelt and the isotope ratios plot within this group, indicating that precipitation is the source for this water. The second grouping of samples (B) includes those main-stem samples collected in June, July, and August and the tributary samples from Fourmile Cr, Sand Cr, Hardscrabble Cr, Ark trib 1 at CR119, Ark trib 2 at CR119, and Ark trib 1 at CR112. Evaporation, decreasing snowmelt runoff, and possible increasing contribution of groundwater that may contain isotopically heavier (higher values of $\delta \mathrm{D}$ and $\delta^{18} \mathrm{O}$ ) irrigation recharge may explain the progression of isotope ratios in water samples collected from the main-stem Arkansas River from being isotopically light in May to heavier in August. No groundwater-isotope samples have been collected in this area of the Arkansas River Basin, however, for comparison to surface-water isotope samples.

The third and isotopically heaviest group of tributary samples (C) includes those collected from Beaver Cr, Ranger $\mathrm{Cr}$, Bear $\mathrm{Cr}$, and Brush Hollow indicating that water from these tributaries either has been substantially affected by evaporation or contains greater amounts of irrigation return flows than Fourmile Cr, Sand Cr, Hardscrabble Cr, Ark trib 1 at CR119, Ark trib 2 at CR119, Ark trib 1 at CR112, and Ark trib 2 at CR112 (fig. 16). Beaver Cr, Ranger Cr, Bear Cr and Brush Hollow drain from the north of the Arkansas River through the irrigated agricultural areas in and around the community of Penrose, Colo. (fig. 9) increasing the potential for greater amounts of irrigation return flows in those tributaries. Brush Hollow Reservoir, northwest of Penrose, provides water storage for irrigation and recreational use and increases the residence time and potential for evaporation of water in Brush Hollow before it flows into the Arkansas River or is diverted for agricultural uses. Conversely, the tributaries, Hardscrabble Cr, Ark trib 1 at CR112, and Ark trib 2 at CR112, drain from the south of the Arkansas River, primarily through range land where agricultural irrigation is limited (fig. 9). The lighter isotopic ratios of Hardscrabble Cr, Ark trib 1 at CR112, and Ark trib 2 at CR112 than Beaver Cr, Ranger Cr, Bear Cr, and Brush Hollow suggest less effects of evaporation to surface waters, groundwater recharge, and possibly less irrigation return flows.

\section{Characteristics of Instantaneous Dissolved Solids, Selenium, and Uranium Loading}

The synoptic sampling events using the Lagrangian sampling design provide an understanding of the in-stream waterquality processes and an opportunity to see water-quality changes for the same parcel of water as it moves downstream. Water quality of the tributaries provides additional information about mass-loading input to the river. Analysis is focused on flows measured during selected synoptic events and the DS 

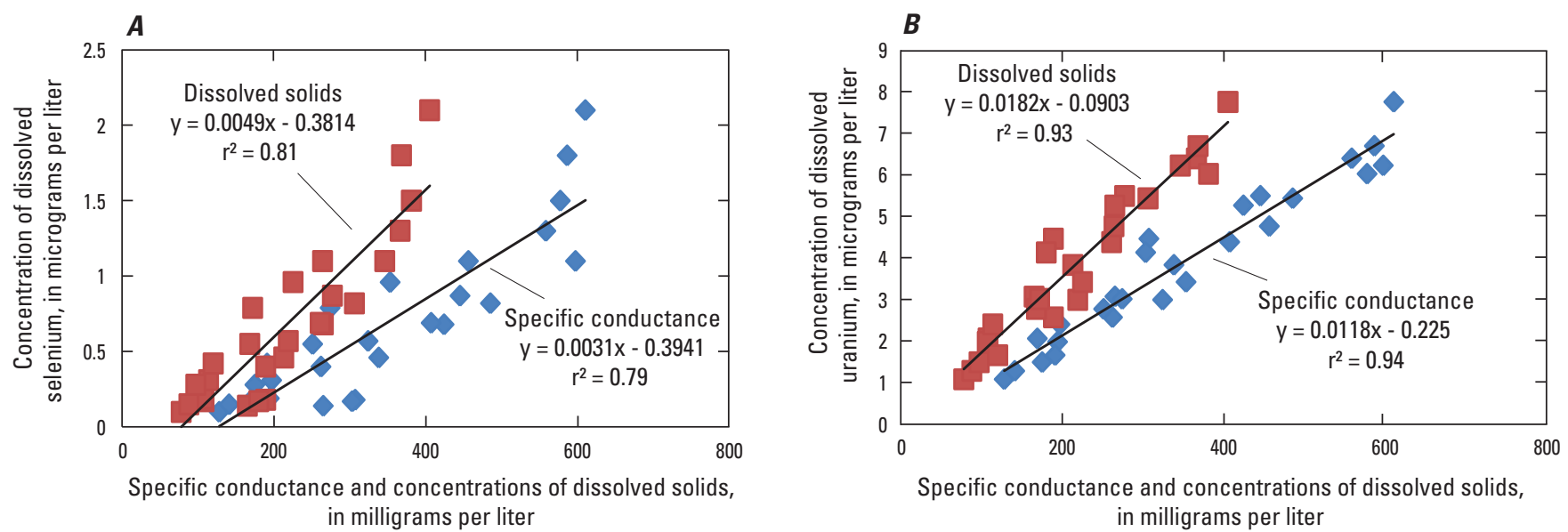

Figure 14. Relation of concentrations of $(A)$ dissolved selenium and $(B)$ dissolved uranium with specific conductance and dissolved solids in the Arkansas River from Canon City to near Portland, 1990-2010.

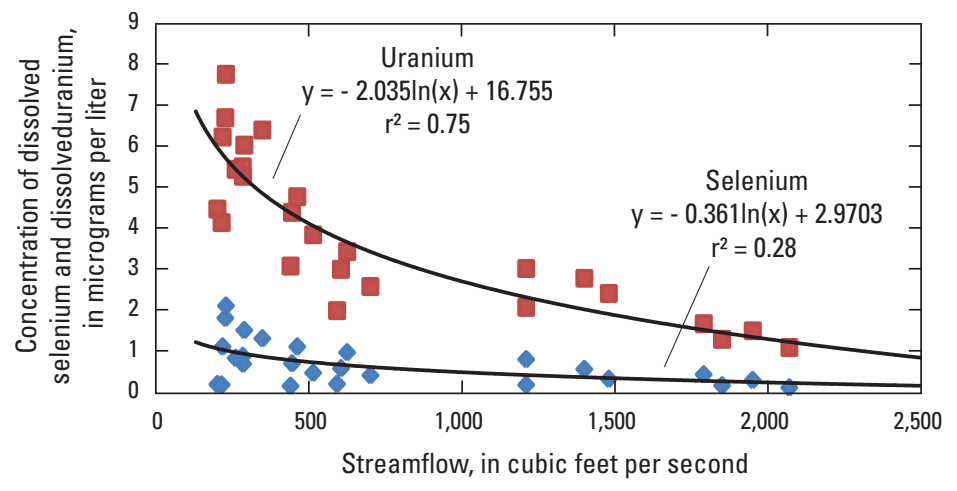

Figure 15. Relation of concentrations of dissolved selenium and dissolved uranium with streamflow in the Arkansas River from Canon City to near Portland, 2009-2010.

concentrations of samples collected during these events. As an example, DS, dissolved selenium, and dissolved uranium loads in the UARB were characterized for the September 15, 2010, synoptic event (low streamflow). Loads for DS were calculated by multiplying the daily mean streamflow, in cubic feet per second, by the constituent concentration, in milligrams per liter, and a unit conversion factor ( 0.0027$)$ to obtain tons per day. Selenium and uranium loads were calculated similar to DS loads, except concentrations were in micrograms per liter, which required a unit conversion factor of 0.0054 to obtain pounds per day.

For the September 15, 2010, synoptic event, from Ark at Canon City to Ark nr Canon City, streamflow increased downstream; however, the contribution $\left(21.9 \mathrm{ft}^{3} / \mathrm{s}\right)$ (table 10) from the measured tributaries, although large in comparison to tributaries in other parts of the UARB, does not account for the increase in streamflow at Ark nr Canon City. This suggests the presence of ungaged inflow(s) in this reach, possibly groundwater; however, groundwater discharge data have not been collected for this reach. In the reach from Ark nr Canon
City to Ark at Portland, the Minnequa Canal (fig. 2) can divert large amounts of water. On September 15, 2010, diversions to this canal were $92.3 \mathrm{ft}^{3} / \mathrm{s}$ (table 10). The effluent from the Fremont WWTP represented approximately 3 percent of the measured streamflow at Ark at Portland; streamflow from the nine measured tributaries accounted for another 4 percent. As for the river reach from Ark at Canon City to Ark nr Canon City, the groundwater contribution to the Arkansas River flow between Ark nr Canon City to Ark at Portland is at present uncharacterized. Measured streamflow decreased in the main-stem sites from Ark at Portland to Ark nr Portland (table 10); however, this decrease (6 percent from Ark at Portland to Ark nr Portland) is within instrument measurement error. Tributaries contributed $4.12 \mathrm{ft}^{3} / \mathrm{s}$ of the measured flow at Ark nr Portland, and as for the other reaches of the UARB, any groundwater contribution is uncharacterized.

Instantaneous DS loads on September 15, 2010, at the main-stem sites in the UARB, increased from Ark at Canon City (102.5 tons per day (tons/d)) to Ark nr Portland (241.7 tons/d) 


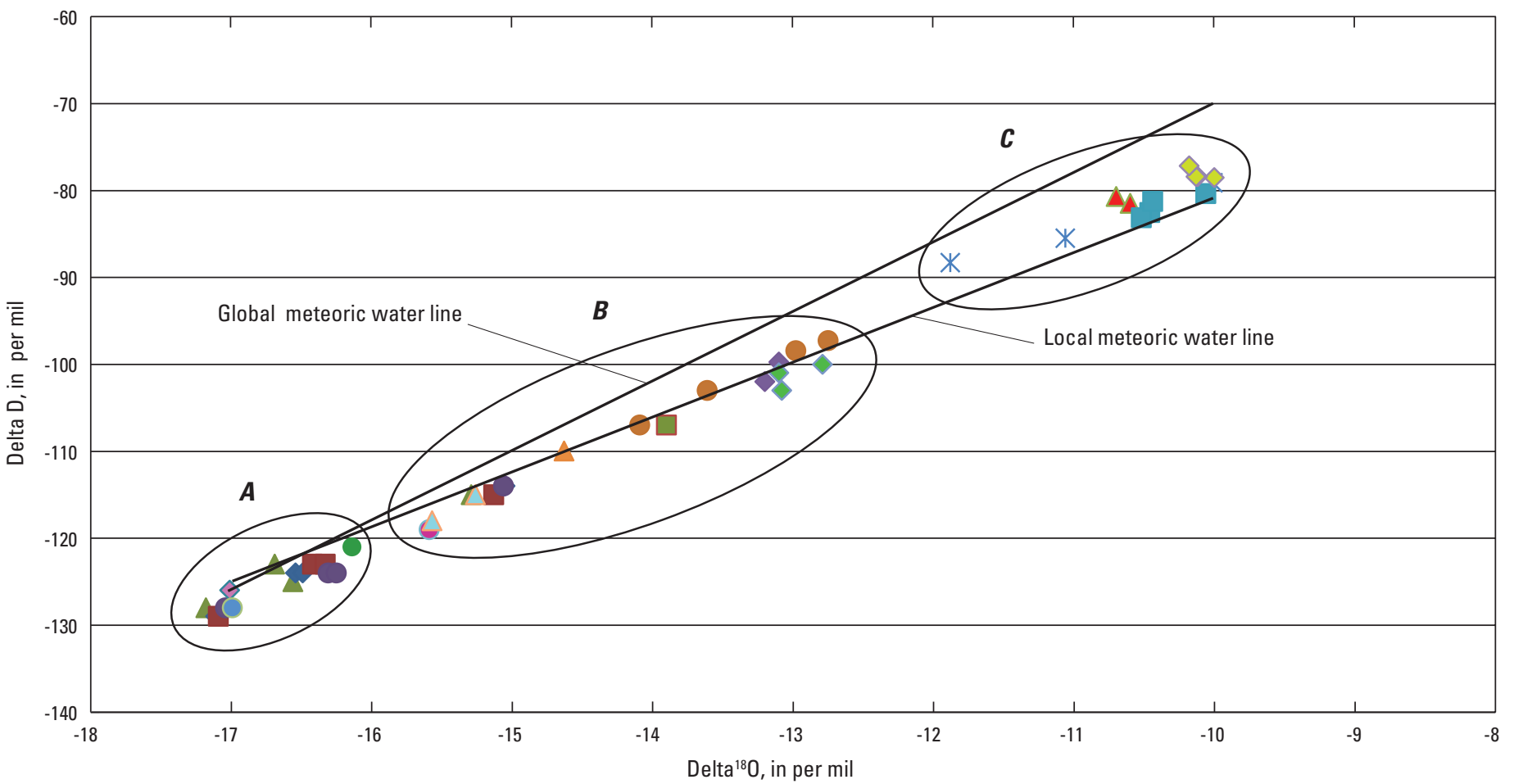

EXPLANATION

$\triangle$ Ark at Canon City

- Ark near Canon City

ark at Portland

Ark near Portland

Lake Cr

- Fourmile $\mathrm{Cr}$

* Beaver $\mathrm{Cr}$

Ark trib 2 at CR119

$\triangle$ Ranger $\mathrm{Cr}$

Ark trib 1 at CR112

Bear Cr

Ark trib 1 at CR119

Hardscrabble $\mathrm{Cr}$

Oak Cr

- Chandler Cr

Brush Hollow

Sand $\mathrm{Cr}$

$\triangle$ Fremont WWTP

Figure 16. Delta $D$ and delta ${ }^{18} 0$ in samples from the Arkansas River and selected tributaries from Canon City to near Portland, 2009-2010. 
(table 10). Tributary loads generally were small compared to main-stem loads. Fourmile Cr, which had the largest tributary load to the river, contributed 25.7 tons/d of the total DS load at Ark nr Canon City (205.3 tons/d) followed by Bear Cr contributing 23.2 tons/d of the total DS load at Ark nr Portland (241.7 tons/d). The Minnequa Canal diverted approximately 32 percent of the total DS load at Ark nr Canon City. The greatest increase in DS load for main-stem sites (table 10) was between Ark at Canon City and Ark nr Canon City.

A Kruskall-Wallis test on DS loads from samples (periodic and synoptic) collected during 2009-2010, excluding high-flow samples collected in May, June, and July, indicated significant differences ( $p$-value $=0.004)$ in instantaneous loads between the main-stem sites. The groundwater DS load contribution to the water quality of the Arkansas River may be small in relation to the surface-water contribution during high-flow periods, and removing the high-flow samples from the data set allows for the groundwater contribution to be accounted for in the statistical analysis. Using the Tukey's test for multiple comparisons to determine which sites were different from each other indicated significant differences between instantaneous DS loads for the main-stem sites from Ark at Canon City to Ark at Portland. Further investigation would be needed to evaluate potential DS source areas within the Arkansas River from Ark at Canon City to Ark at Portland.

To estimate the DS load and to calculate concentration originating from ungaged contributions $(+)$ or losses $(-)$ between main-stem sites, mass balance equations were developed for use with the data from the synoptic events:

$$
\begin{aligned}
& Q_{u c}=Q_{m d r}-Q_{m u r}-Q_{m c t r}+Q_{m c d r} \\
& D S L_{u c}=D S L_{m d r}-D S L_{m u r}-D S L_{m c t r}+D S L_{m c t r} \\
& D S C_{u c}=D S L_{u c} \div 0.0027
\end{aligned}
$$

where the main variables are

$Q \quad$ is streamflow, in cubic feet per second;

$D S L \quad$ is dissolved-solids load, in tons per day; and

DSC is dissolved solid concentration, in milligrams per liter;

and the subscripts associated with the main variables are

$u c \quad$ is ungaged contributions (+) or losses (-) within the reach;

$m d r \quad$ is measured Q or calculated DSL at downstream end of main-stem reach;

mur is measured Q or calculated DSL at upstream end of main-stem reach;

mctr is measured Q or calculated DSL contributions from tributaries within the reach; and

$m c d r \quad$ is measured Q or calculated DSL losses (-) from diversions within the reach.
The factor 0.0027 is used to convert units in equation 5 to milligrams per liter.

For the reach from Ark at Canon City to Ark nr Canon City for the synoptic event of September 15, 2010, streamflow in the main-stem increased from $211 \mathrm{ft}^{3} / \mathrm{s}$ at Ark at Canon City to $287 \mathrm{ft}^{3} / \mathrm{s}$ at Ark nr Canon City (table 10). The measured contribution to streamflow from tributaries within the reach was $21.9 \mathrm{ft}^{3} / \mathrm{s}$. No diversions were present within the reach. Therefore, the ungaged streamflow from contributions within the reach was calculated to be $54.1 \mathrm{ft}^{3} / \mathrm{s}$. The DS load in the same reach increased from 102.5 tons/d at Ark at Canon City to 205.3 tons/d at Ark nr Canon City. The contribution to the DS load from tributaries was calculated to be 29.7 tons/d. Therefore, the DS load from ungaged contributions within the reach was estimated to be 73.1 tons/d. Assuming a single source, such as groundwater discharge, for all the ungaged streamflow and DS load from ungaged contributions, the DS concentration of the single source is calculated to be $500.4 \mathrm{mg} / \mathrm{L}$.

For the reach from Ark nr Canon City to Ark at Portland for the same synoptic event, the streamflow from ungaged contributions within the reach was calculated to be $22.9 \mathrm{ft}^{3} / \mathrm{s}$ and the DS load was calculated to be 43.7 tons/d. Assuming a single source, such as groundwater discharge, for all the ungaged streamflow and ungaged contributions to DS load, the DS concentration of the ungaged single source is calculated to be $706.8 \mathrm{mg} / \mathrm{L}$ (table 10 ).

For the reach from Ark at Portland to Ark nr Portland, for September 15, 2010, the streamflow from ungaged losses within the reach was calculated to be $-15.1 \mathrm{ft}^{3} / \mathrm{s}$ and the ungaged contribution to DS load was -7.8 tons/d. Assuming a single source for these ungaged losses, such as leakage from the river to groundwater, for all the ungaged streamflow and ungaged contributions to DS load, the DS concentration of the ungaged single source is calculated to be $191 \mathrm{mg} / \mathrm{L}$ (table 10). The negative value for streamflow in the reach between Ark at Portland and Ark nr Portland indicates that for the period evaluated, the Arkansas River within this reach is losing water to the aquifer, or inflows and loads from ungaged sources are smaller than discharge from the Arkansas River to the aquifer. The ungaged streamflow, ungaged contributions to DS load, and DS concentration for an assumed ungaged single source for all three reaches in the UARB are applicable only for September 2010, and may likely vary throughout the year for different streamflow and water-quality conditions. Substantial differences between DS concentration in the main stem and for the ungaged contributions could indicate unaccounted for inputs or losses in the reach or streamflow measurement error.

Groundwater in Quaternary alluvial deposits hydraulically connected to the Arkansas River and tributaries in the UARB is reported to have a median DS concentration of $220 \mathrm{mg} / \mathrm{L}$, with concentrations ranging from 100 to more than $1,000 \mathrm{mg} / \mathrm{L}$ (Miller and others, 2010). Calculated DS concentrations of ungaged sources in each of the reaches in the UARB are within the reported range of groundwater DS concentrations; therefore, groundwater is a plausible source for 
Table 10. Measured and calculated ungaged streamflow, contributions to dissolved-solids load, and dissolved-solids concentration for three reaches in the Upper Arkansas River Basin, September 15, 2010.

[Complete site names given in table 1; UC, ungaged contribution; negative numbers indicate a loss of water from the river]

\begin{tabular}{|c|c|c|c|c|}
\hline Reach & $\begin{array}{c}\text { Site name or component } \\
\text { of flow }\end{array}$ & $\begin{array}{l}\text { Streamflow, in } \\
\text { cubic feet per } \\
\text { second }\end{array}$ & $\begin{array}{c}\text { Dissolved solids } \\
\text { concentration, } \\
\text { in milligrams per } \\
\text { liter }\end{array}$ & $\begin{array}{l}\text { Dissolved solids load, } \\
\text { in tons per day }\end{array}$ \\
\hline \multirow{4}{*}{ Reach 1} & Ark at Canon City & 211 & 180 & 102.5 \\
\hline & Tributaries $^{3}$ & 21.9 & 864 & 29.7 \\
\hline & $\mathrm{UC}$ & 54.1 & $500.4^{1}$ & 73.1 \\
\hline & Ark nr Canon City & 287 & 265 & 205.3 \\
\hline \multirow{5}{*}{ Reach 2} & Ark nr Canon City & 287 & 265 & 205.3 \\
\hline & Tributaries $^{3}$ & 14.4 & 10,179 & 33.7 \\
\hline & Diversions & -92.3 & 265 & -66 \\
\hline & $\mathrm{UC}$ & 22.9 & $706.8^{1}$ & 43.7 \\
\hline & Ark at Portland & 232 & 346 & 216.7 \\
\hline \multirow{4}{*}{ Reach 3} & Ark at Portland & 232 & 346 & 216.7 \\
\hline & Tributaries $^{3}$ & 4.12 & 21,180 & 32.8 \\
\hline & $\mathrm{UC}^{2}$ & -15.1 & $191^{1}$ & -7.8 \\
\hline & Ark nr Portland & 221 & 405 & 241.7 \\
\hline
\end{tabular}

${ }^{1}$ Value is based on the assumption that the ungaged contribution (UC) is from a single source.

${ }^{2}$ No ungaged contributions quantified within this reach.

${ }^{3}$ Dissolved solids concentration summed for all tributaries in the reach.

the ungaged contribution to DS loads. In addition to groundwater, however, ungaged irrigation return flow and ungaged tributaries may also be sources of DS loads, but the contributions from these sources are unknown.

Selenium loads in the Arkansas River on September 15, 2010 (table 11), increased from 0.19 pounds per day (lbs/d) at Ark at Canon City to $1.05 \mathrm{lbs} /$ day at Ark nr Canon City, an increase of $0.86 \mathrm{lbs} / \mathrm{d}$, to $1.38 \mathrm{lbs} / \mathrm{d}$ at Ark at Portland, an increase of $0.33 \mathrm{lbs} / \mathrm{d}$, and to $2.51 \mathrm{lbs} / \mathrm{d}$ at Ark nr Portland, an increase of $1.13 \mathrm{lbs} / \mathrm{d}$. Tributary loads or load removal through the Minnequa Canal were not calculated for September 15, 2010, as no tributary or Minnequa Canal selenium samples were collected. The Rainbow Park WWTP, however, contributes approximately $0.12 \mathrm{lbs} / \mathrm{d}$ to the selenium load at Ark at Portland.

A Kruskall-Wallis test was done using selenium loads for all samples (periodic and synoptic) collected during 2009-2010. High-flow samples were not removed from the data set, because too few samples would have been available for analysis. Statistically significant ( $p$-value $\leq 0.0005$ ) differences were found between dissolved selenium loads at the main-stem sites. Using the Tukey's test for multiple comparisons, the differences between selenium loads are significant for the reach from Ark at Canon City to Ark at Portland, suggesting this section of the Arkansas River is the likely source for the increase in selenium loads. With the available selenium load data, the reach from Ark at Portland to Ark nr Portland was not statistically significant as a possible source for selenium loads, even though selenium loads in this reach increased by $1.13 \mathrm{lbs} / \mathrm{d}$ on September 15, 2010.

Uranium loads on September 15, 2010 (table 11), for main-stem sites generally increased downstream from 4.71 lbs/d at Ark at Canon City, to $8.15 \mathrm{lbs} / \mathrm{d}$ Ark nr Canon City, to $7.79 \mathrm{lbs} / \mathrm{d}$ at Ark at Portland, and to $9.25 \mathrm{lbs} / \mathrm{d}$ at Ark nr Portland. Tributary or Rainbow Park WWTP loads and load removal through the Minnequa Canal were not calculated for September 15, 2010, as no tributary, WWTP, or Minnequa Canal uranium samples were collected. A Kruskall-Wallis test on uranium loads from main-stem samples (periodic and synoptic) collected during 2009-2010 indicated (p-value 0.224) no statistically significant differences between instantaneous loads at the main-stem sites. 
Table 11. Change in streamflow and loads of dissolved solids, selenium, and uranium between main-stem sites in the Upper Arkansas River Basin, September 15, 2010.

[Complete site names given in table 1]

\begin{tabular}{|c|c|c|c|c|c|c|}
\hline \multirow{2}{*}{ Site name } & \multirow{2}{*}{$\begin{array}{c}\text { Streamflow, } \\
\text { in cubic feet } \\
\text { per second }\end{array}$} & \multicolumn{2}{|c|}{ Percent change } & \multirow{2}{*}{$\begin{array}{c}\text { Dissolved } \\
\text { solids load, } \\
\text { in tons per } \\
\text { day }\end{array}$} & \multicolumn{2}{|c|}{ Percent change } \\
\hline & & $\begin{array}{l}\text { Within } \\
\text { reach }\end{array}$ & Cumulative & & $\begin{array}{l}\text { Within } \\
\text { reach }\end{array}$ & Cumulative \\
\hline Ark at Canon & 211 & & & 102.5 & & \\
\hline Ark nr Canon & 287 & 36 & 36 & 205.3 & 100 & 100 \\
\hline Ark at Portland & 232 & -19 & 10 & 216.7 & 6 & 111 \\
\hline Ark nr Portland & 221 & -5 & 5 & 241.7 & 12 & 136 \\
\hline \multirow{2}{*}{ Site name } & \multirow{2}{*}{$\begin{array}{l}\text { Selenium } \\
\text { load, in } \\
\text { pounds per } \\
\text { day }\end{array}$} & \multicolumn{2}{|c|}{ Percent change } & Uranium & \multicolumn{2}{|c|}{ Percent change } \\
\hline & & $\begin{array}{l}\text { Within } \\
\text { reach }\end{array}$ & Cumulative & $\begin{array}{l}\text { pounds } \\
\text { per day }\end{array}$ & $\begin{array}{l}\text { Within } \\
\text { reach }\end{array}$ & Cumulative \\
\hline Ark at Canon & .19 & & & 4.71 & & \\
\hline Ark nr Canon & 1.05 & 453 & 453 & 8.15 & 73 & 73 \\
\hline Ark at Portland & 1.38 & 31 & 626 & 7.79 & -4 & 65 \\
\hline Ark nr Portland & 2.51 & 82 & 1,221 & 9.25 & 19 & 96 \\
\hline
\end{tabular}

Characteristics of Streamflow, Water Quality, and Instantaneous Dissolved Solids, Selenium, and Uranium Loads in the Arkansas River Basin from Avondale to Las Animas

Streamflow and water quality in the LARB from Avondale to Las Animas are influenced by natural and anthropogenic factors associated with land- and water-use practices. Irrigation diversions have been expanded since the first diversion rights were granted in the early 1830s (The Ditch Project, 2011) to move water from the Arkansas River to fields in the valley. Streamflow was measured at both long-term and at study-specific temporary gages for use in water-quality analysis and computing instantaneous loads. Data for periodic as well as synoptic water-quality samples were used to assess water quality and instantaneous loads of dissolved solids, selenium, and uranium.

\section{Streamflow Characteristics}

In the LARB, long-term (pre-2000) data are available for six main-stem stations-Ark nr Avondale, Ark at Nepesta, Ark at Catlin Dam, Ark nr Rocky Ford, Ark at La Junta, and Ark at Las Animas (fig. 17). The streamflow-gaging stations for Ark nr Avondale and Ark at Las Animas are maintained and administered by the USGS (U.S. Geological Survey, 2012), whereas gaging stations at Ark nr Nepesta, Ark at Catlin Dam, Ark nr Rocky Ford, and Ark at La Junta are administered by Colorado Division of Water Resources (2011). A temporary gage was installed and operated by the USGS at the Ark at Swink station for this study, and streamflow records were collected for 2009 through 2010.

The hydrographic record from 1990 through 2010 for all six long-term gages on the main-stem Arkansas River in the LARB are shown in figure 17; data collection for Ark nr Rocky Ford did not begin until 1999. Summary statistics for 1990-2008 and 2009-2010 are shown for each station in table 12. The 2009-2010 hydrographs for the six main-stem stations were similar to hydrographs for those same sites for previous years, with the exception of the years 1999 and 2002. The high flows in April 1999 resulted from a large storm and caused flooding of Fountain Creek (National Center for Atmospheric Research, 2011) and the low flows in 2002 account for the differences in the maximum and minimum flows between the historical record and the 2009-2010 study period (fig. 17). However, for most of the six sites, the median and mean flows for the two periods are similar.

Annual hydrographs for 2009-2010 are available for three tributary stations (fig. 18A), Huerfano R, Timpas Cr, and Crooked Arroyo. Median flows for the three tributaries having annual records ranged from $3.2 \mathrm{ft}^{3} / \mathrm{s}$ in Crooked Arroyo to $67.5 \mathrm{ft}^{3} / \mathrm{s}$ in Timpas Cr. During the study period, Timpas $\mathrm{Cr}$ had the highest maximum flow, $684 \mathrm{ft}^{3} / \mathrm{s}$, while the Huerfano $\mathrm{R}$ was dry during parts of this study. 

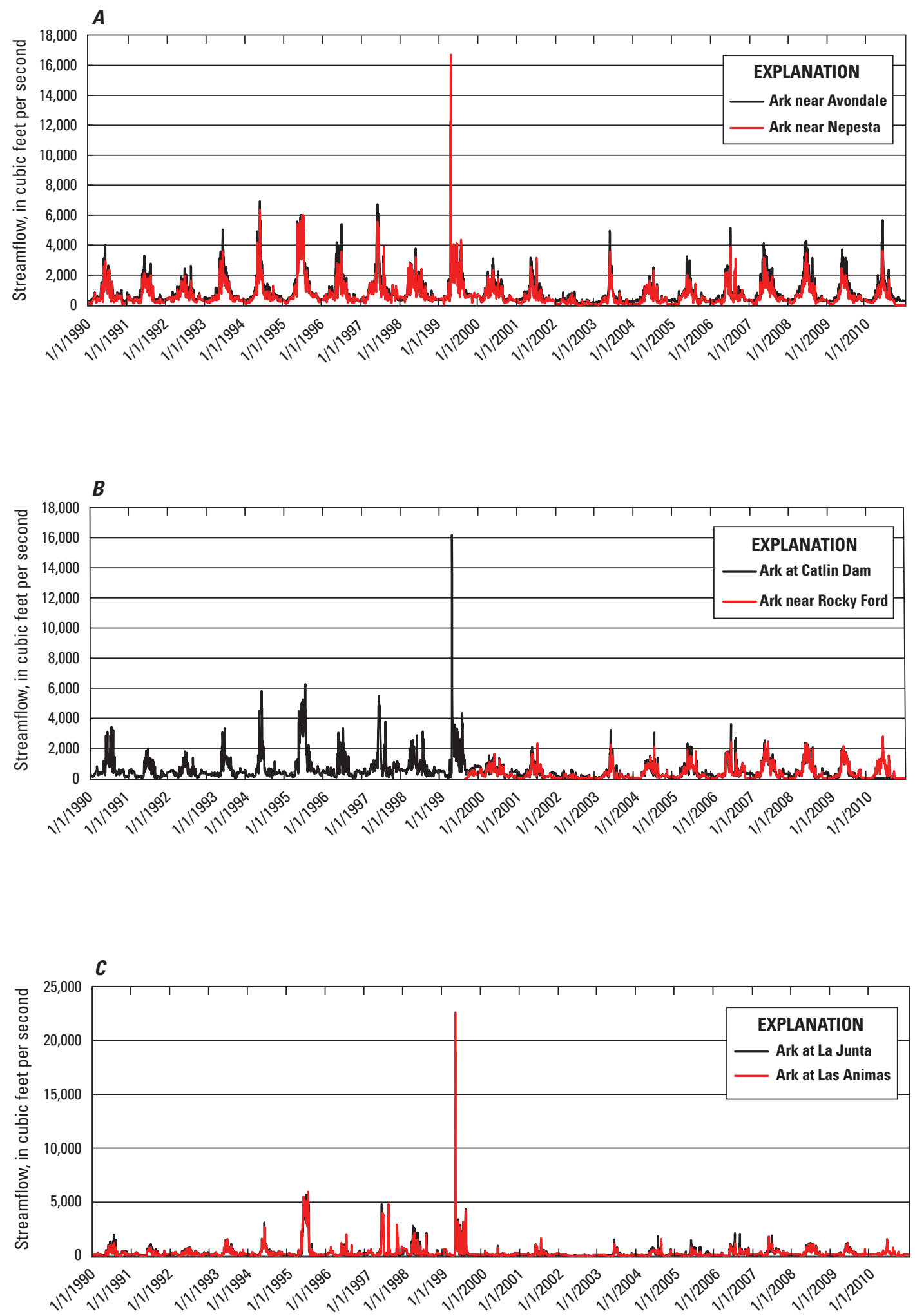

Figure 17. Streamflow hydrographs in the Arkansas River: $(A)$ Arkansas River near Avondale and Arkansas River near Nepsta, $(B)$ Arkansas River at Catlin Dam and Arkansas River near Rocky Ford, (C) Arkansas River at La Junta and Arkansas River at Las Animas, 1990-2010. 
Table 12. Summary statistics for Arkansas River streamflow data 1990-2008 and 2009-2010 for Ark at Avondale, Ark nr Nepesta, Ark at Catlin Dam, Ark nr Rocky Ford, Ark at La Junta, and Ark at Las Animas gage stations.

[Complete site names given in table $1 ; \mathrm{ft}^{3} / \mathrm{s}$, cubic feet per second]

\begin{tabular}{lcccccccc}
\hline \multirow{2}{*}{ Site name } & \multicolumn{2}{c}{ Maximum flow, $\mathbf{f t}^{3} / \mathbf{s}$} & \multicolumn{2}{c}{ Minimum flow, $\mathbf{f t}^{3} / \mathbf{s}$} & \multicolumn{2}{c}{ Median flow, $\mathbf{f t}^{3} / \mathbf{s}$} & \multicolumn{2}{c}{ Mean flow, $\mathbf{f t}^{3} / \mathbf{s}$} \\
& $\mathbf{1 9 9 0 - 2 0 0 8}$ & $\mathbf{2 0 0 9 - 2 0 1 0}$ & $\mathbf{1 9 9 0 - 2 0 0 8}$ & $\mathbf{2 0 0 9 - 2 0 1 0}$ & $\mathbf{1 9 9 0 - 2 0 0 8}$ & $\mathbf{2 0 0 9 - 2 0 1 0}$ & $\mathbf{1 9 9 0 - 2 0 0 9}$ & $\mathbf{2 0 0 9 - 2 0 1 0}$ \\
\hline Ark nr Avondale & 12,300 & 5,660 & 87 & 194 & 565 & 517 & 884 & 823 \\
Ark nr Nepesta & 16,700 & 3,610 & 1.6 & 80 & 431 & 402 & 681 & 622 \\
Ark at Catlin Dam & 16,200 & 5,660 & .53 & 194 & 352 & 517 & 571 & 823 \\
Ark nr Rocky Ford & 2,440 & 2,800 & .41 & 23 & 172 & 215 & 340 & 446 \\
Ark at La Junta & 19,000 & 1,220 & 3.4 & 26 & 93 & 115 & 269 & 253 \\
Ark at Las Animas & 22,600 & 1,560 & 7.5 & 26 & 123 & 133 & 278 & 211 \\
\hline
\end{tabular}

${ }^{1}$ Data are available only for $1990-2010$.

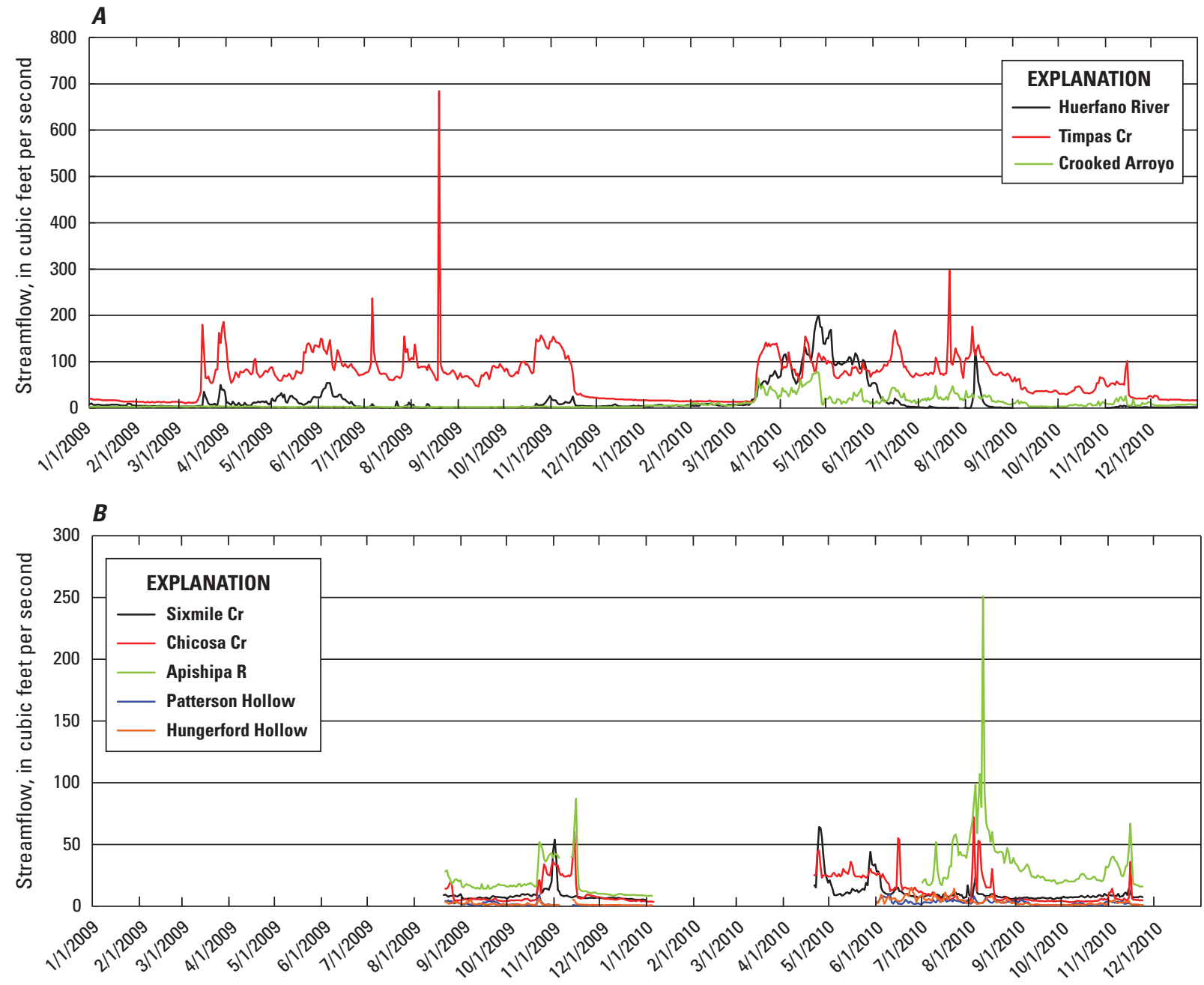

Figure 18. Annual streamflow hydrographs $(A)$ for Huerfano River, Timpas Creek, and Crooked Arroyo and seasonal hyrdrographs $(B)$ for Sixmile Creek, Chicosa Creek, Apishipa River, Patterson Hollow, and Hungerford Hollow, 2009-2010. 
Seasonal hydrographs for 2009-2010 are available for five stations (fig. 18B); Sixmile Cr, Chicosa Cr, Apishipa R, and Patterson and Hungerford Hollows. Of the seasonally measured tributaries, the lowest flow, $0.25 \mathrm{ft}^{3} / \mathrm{s}$, was measured in Patterson Hollow, the highest maximum flow, $251 \mathrm{ft}^{3} / \mathrm{s}$, was measured in the Apishipa R. Median flows in these tributaries ranged from $1.7 \mathrm{ft}^{3} / \mathrm{s}$ in Hungerford and Patterson Hollows to $21 \mathrm{ft}^{3} / \mathrm{s}$ in the Apishipa R. In general, streamflow in the tributaries is less than in the Arkansas River, and larger instantaneous flows are associated with storm runoff. Seasonal increases in streamflows in many of these tributaries can be attributed to irrigation return flows during the growing season and, in turn, seasonal decreases in streamflows during the fall and winter months can be attributed to reduced irrigation return flow (fig. 18).

\section{Water-Quality Characteristics}

Water samples from the main stem and tributaries were analyzed for selected constituents to characterize the Avondale to Las Animas reach of the Arkansas River and to identify potential source areas for dissolved solids, selenium, and uranium. Constituents sampled include specific conductance, major ions, dissolved solids, nutrients, select dissolved trace elements (selenium and uranium), and hydrogen and oxygen isotopes. Larger scale Arkansas River Basin water-quality studies (Dash and Ortiz, 1996; Ortiz and others, 1998) began in the 1990s; previous to this, studies were generally limited in scope and scale. To increase the number of observations and the power of statistical tests in this study, water-quality data from Dash and Ortiz (1996) and Ortiz and others (1998) beginning in 1990 were included in selected data sets.

\section{Specific Conductance}

Specific conductance values within the LARB generally increased downstream from Ark nr Avondale to Ark at Las Animas during 2009-2010 (fig. 19). Temporally, the lowest SC values occurred in June in both 2009 and 2010, whereas the highest values measured occurred in March and April. Spring runoff (predominantly snowmelt low in dissolved solids) and releases from Pueblo Reservoir in May and June produce high flows in the river with a low SC. In March and April, most of the streamflow in the river is presumably irrigation recharged groundwater, which could have a high SC.

\section{Major lons}

Water in the main stem of the LARB is a calcium-sulfate type, as reported previously by Ortiz and others (1998), and is likely a result of groundwater and surface-water interaction with marine shales and sandstones of Cretaceous age containing calcareous cements and marine limestones (fig. 20). The calcium-sulfate water type dominates from Avondale to Las Animas; however, the concentrations of the major ions increase downstream from Avondale to a maximum at Las Animas (fig. 21). Use and reuse of irrigation return flows (Miller and others, 2010) and inflows from groundwater are the likely causes for the increase in major ions.

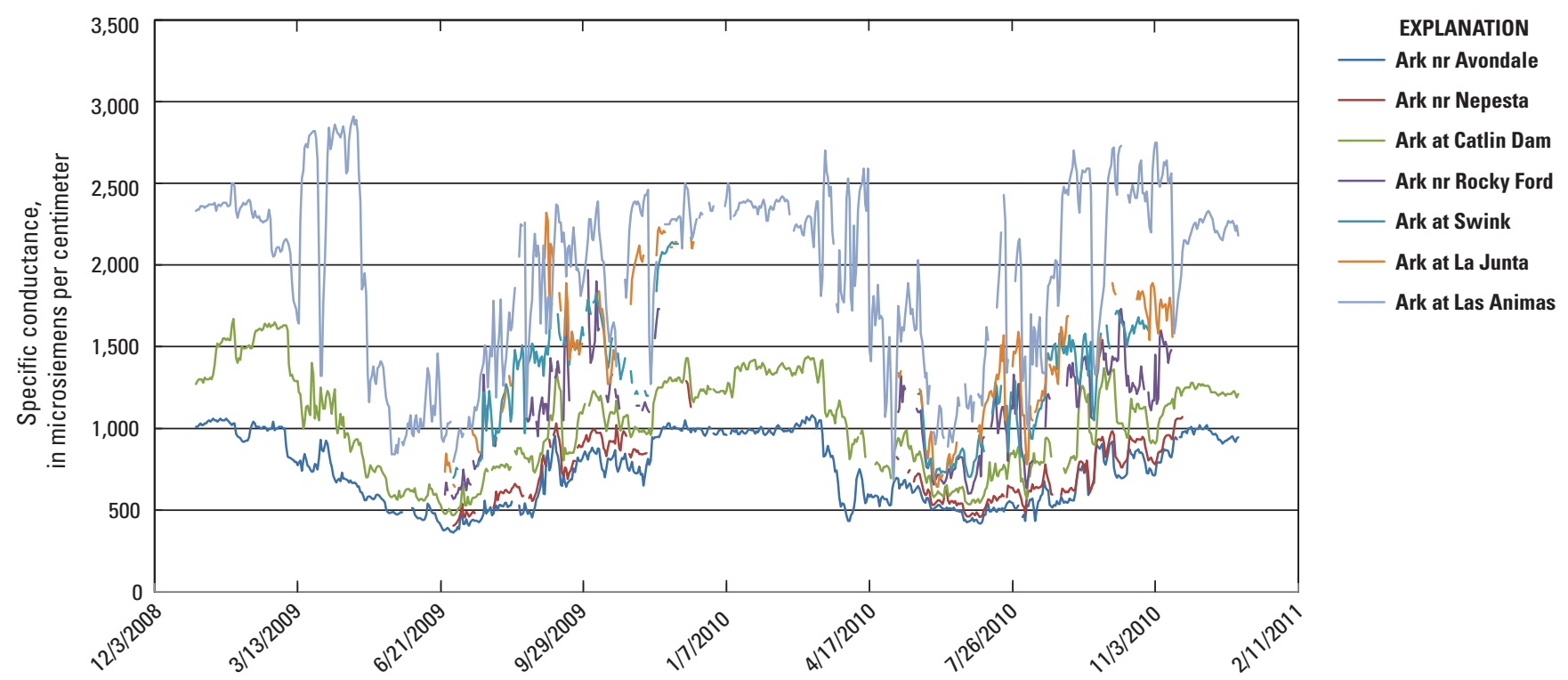

Figure 19. Continuous specific conductance values at main-stem sites in the Arkansas River Basin from Avondale to Las Animas, 2009-2010. 


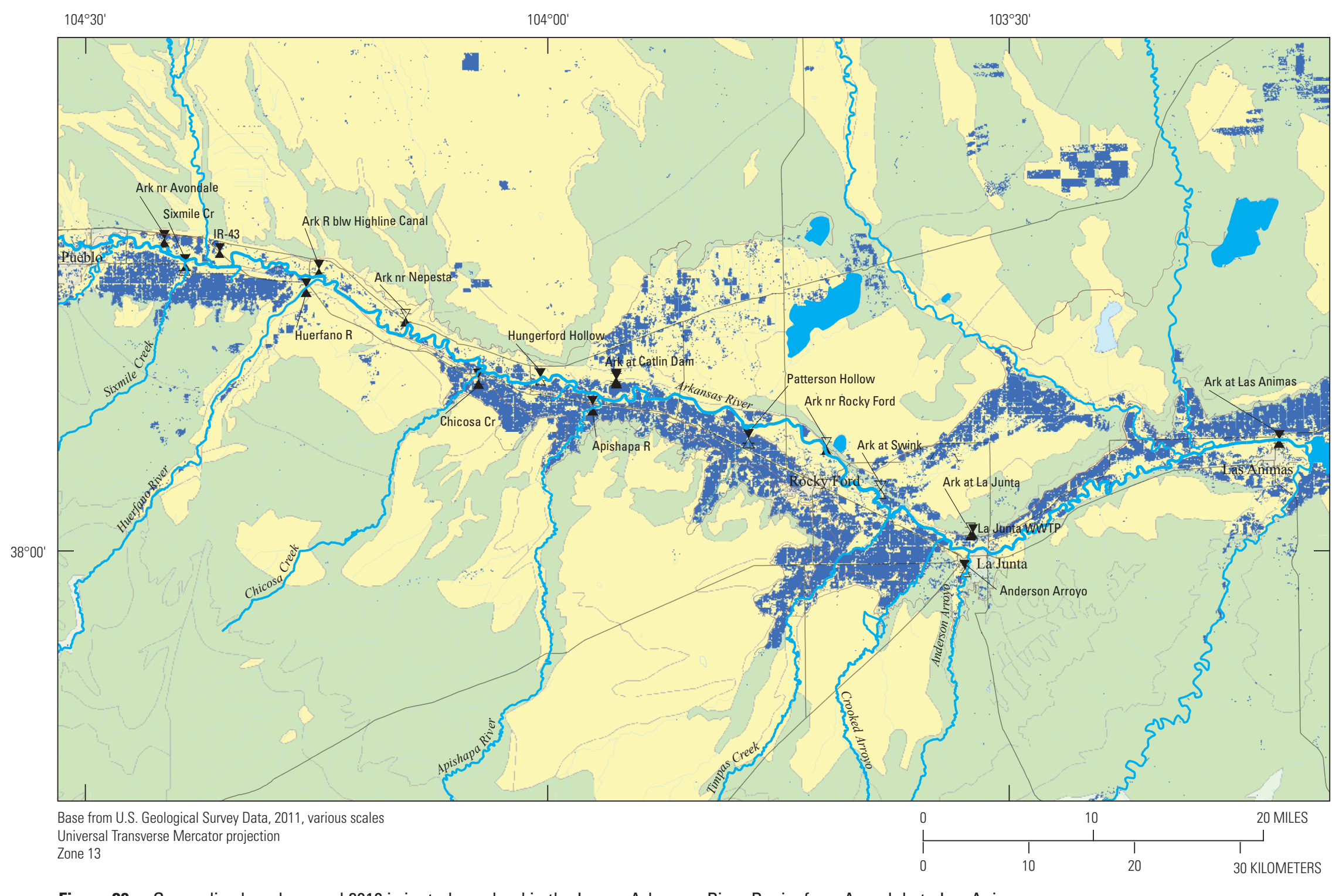

Figure 20. Generalized geology and 2010 irrigated cropland in the Lower Arkansas River Basin, from Avondale to Las Animas. 


\section{EXPLANATION}

Ouaternary alluvial deposits
Sedimentary rocks of Cretaceous age
Pierre Shale
Niobara Formation
Geology modified from Green (1992)
IR-43
Periodic streamflow and periodic water-quality site and site name
$\begin{aligned} & \text { Anderson Arroyo } \\ & \text { Seasonal continuous streamflow and periodic water-quality site and site name }\end{aligned}$
$\begin{aligned} & \text { Ark at Catlin Dam } \\ & \text { Long-term continuous discharge and periodic water-quality site with long-term water-quality } \\ & \text { monitoring and site name }\end{aligned}$
$\begin{aligned} & \text { Ark at Swink } \\ & \text { Seasonal continuous discharge and periodic water-quality site with seasonal water-quality } \\ & \text { monitoring and site name }\end{aligned}$
2010 irrigated cropland; modified
from U.S. Department of Agriculture (2011)

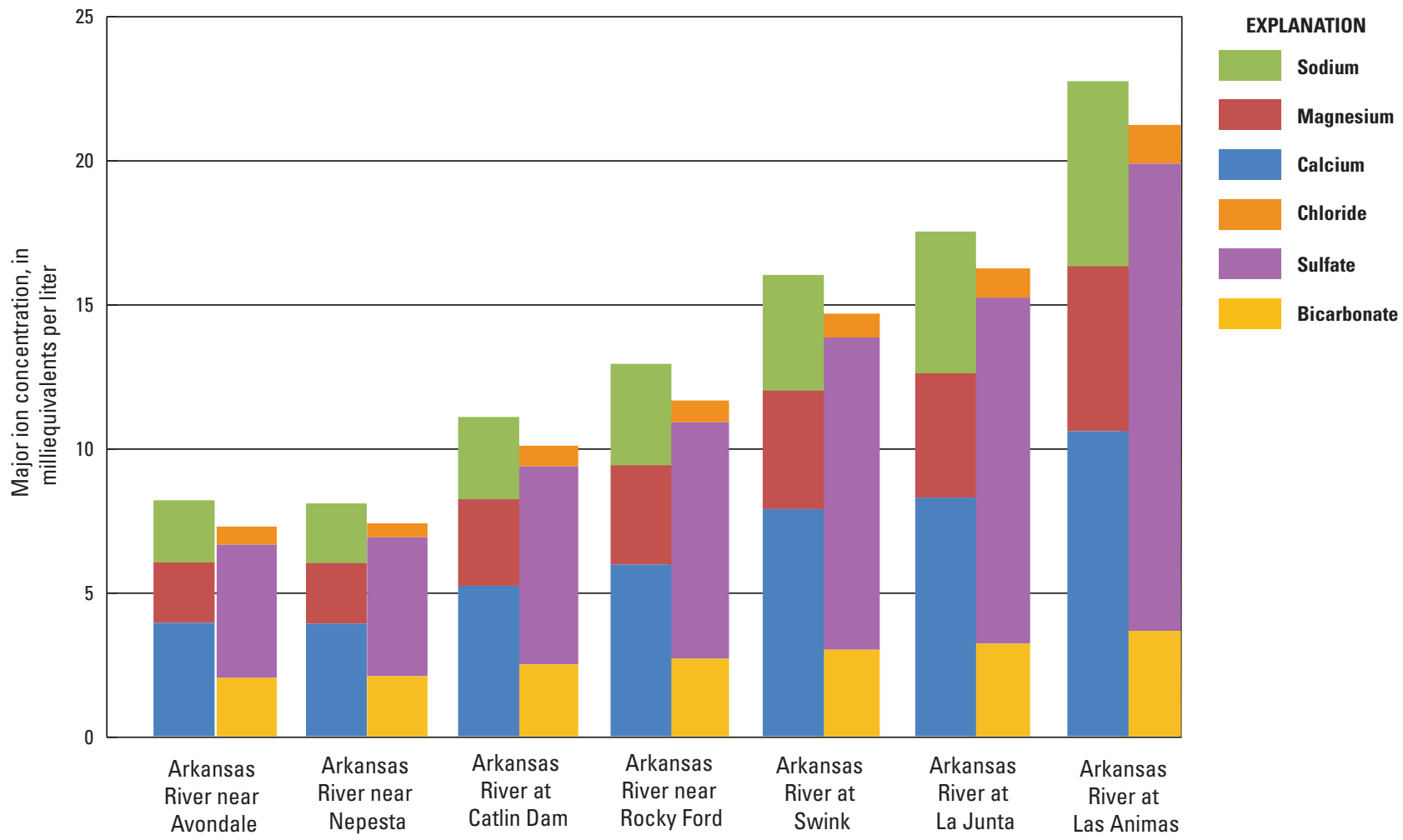

Figure 21. Comparison of median concentrations of six major ions in the Arkansas River, from Avondale to Las Animas, 2009-2010. 


\section{Dissolved Solids}

Similar to the findings of Ortiz and others (1998) and Miller and others (2010), the LARB main-stem median DS concentrations generally increase downstream (fig. 22) from Avondale $(557 \mathrm{mg} / \mathrm{L})$ to Las Animas $(1,725 \mathrm{mg} / \mathrm{L})$. Median DS concentrations in samples from tributaries and the La Junta WWTP varied, ranging from a low of $1,050 \mathrm{mg} / \mathrm{L}$ in Hungerford Hollow to a high of $2,770 \mathrm{mg} / \mathrm{L}$ in water sampled from the Huerfano R. The Huerfano R., in addition to having the highest measured median DS concentration of the sampled tributaries, has the largest range of DS concentrations, from $774 \mathrm{mg} / \mathrm{L}$ to $5,640 \mathrm{mg} / \mathrm{L}$. Irrigation return flows (Miller and others, 2010) and inflows from groundwater likely contribute to the high DS concentrations in all the tributaries, whereas differences in the ranges of DS concentration among the selected tributaries can be attributed to differences in geology and the chemical composition of the bedrock among the tributary basins (fig. 20).

Dissolved-solids concentrations at the main-stem LARB Arkansas River sites were analyzed and compared to specific conductance and streamflow. Table 13 lists results of the linear regression analysis of DS and SC from water samples collected in 2009-2010 from individual sites. All of the sites, even with a small number of samples (less than 10), indicate a significant relation between DS and $\mathrm{SC}\left(\mathrm{r}^{2}>0.95\right)$. As in the UARB, the likely sources of DS in the LARB are geologic units and the continuous recharge and reuse of irrigation water that results in increased concentrations of DS (Miller and others, 2010).

A relation was developed between main-stem Arkansas River flow and DS concentrations. The natural log of DS is moderately correlated to the natural $\log$ of flow $\left(\mathrm{r}^{2}=0.59\right.$; p-value $<0.00001$ ) for the 2009-2010 main-stem site data set (fig. 23A). Regression analysis of the combined data set of DS for all tributary sites for the same period showed minimal correlation $\left(\mathrm{r}^{2}=0.16\right)$ to the natural $\log$ of streamflow (fig. $23 B$ ), indicating that streamflow would not be a reasonable variable to estimate DS concentrations in the tributaries. However, additional paired DS samples and streamflow measurements, in a variety of flow regimes, could be used to build a statistical relation for each tributary.

\section{Nutrients}

Multiple nutrient samples were collected during 2009-2010 from selected main-stem sites, which include Ark at Nepesta, Ark nr Rocky Ford, Ark at Swink, and Ark at La Junta. One set of nutrient samples was collected during 2009-2010 at each of 10 selected tributary sites-Sixmile Cr, IR-43, Huerfano R, Chicosa Cr, Hungerford Hollow, Apishipa R, Patterson Hollow, Timpas Cr, Crooked Arroyo, and Anderson Arroyo. For samples collected from 1990-2010, concentrations of dissolved nitrite-plus-nitrate concentrations from samples collected from Arkansas River main-stem and tributary sites ranged from a low of $1.43 \mathrm{mg} / \mathrm{L}$, at Ark nr Nepesta, to a high of $2.73 \mathrm{mg} / \mathrm{L}$, at Ark at La Junta (fig. 24A). The median nitrite-plus-nitrate concentration was constant from Ark nr Avondale to Ark at Swink, increased at Ark at La Junta and decreased downstream at Ark at Las Animas. Median concentrations of nitrite-plus-nitrate in samples collected from tributaries ranged from a low of $0.35 \mathrm{mg} / \mathrm{L}$ at Huerfano $\mathrm{R}$, to a high of $3.07 \mathrm{mg} / \mathrm{L}$ at Crooked Arroyo (fig. 24A). The concentrations of nitrite-plus-nitrate in Crooked Arroyo and Apishipa River may be contributing to the concentrations at Ark at La Junta and Ark at Catlin Dam, respectively. As in the UARB, concentrations of dissolved nitrite-plus-nitrate for the LARB did not exceed the USEPA drinking-water standard $(10 \mathrm{mg} / \mathrm{L}$ as nitrogen) (U.S. Environmental Protection Agency, 2011).

Multiple total phosphorus samples were collected during 2009-2010 for Ark nr Nepesta, Ark nr Rocky Ford, Ark at Swink, and Ark at La Junta; however, to increase the amount of data for comparison, the boxplots shown in figure $24 B$ are based on samples collected from 1990 through 2010 (Ortiz and others, 1998; and Miller and others, 2010). The median total phosphorus concentrations for the five main-stem sites decreased downstream from $0.3 \mathrm{mg} / \mathrm{L}$ at Ark nr Avondale to $0.1 \mathrm{mg} / \mathrm{L}$ at Ark at Las Animas. Total phosphorous currently does not have a USEPA primary or secondary drinking-water standard (U.S. Environmental Protection Agency, 2011).

\section{Trace Elements}

Concentrations of dissolved selenium and dissolved uranium were analyzed in samples collected from main-stem and selected tributary sites during 2009-2010. Samples for trace-element analyses were collected more frequently at the main-stem sites than at sites on the selected tributaries (table 3). Median dissolved selenium concentrations at the main-stem sites ranged from 8.4 to $12.2 \mu \mathrm{g} / \mathrm{L}$, increasing downstream from Ark nr Nepesta to Ark at La Junta (fig. 25A). However, the median selenium concentration decreased between Ark at La Junta and Ark at Las Animas, the most downstream site in the study area. Miller and others (2010) reported that historical selenium concentrations were variable between Ark nr Avondale and Ark at Las Animas.

Median dissolved selenium concentrations for tributaries generally were higher than those for main-stem sites; however, the median concentration at tributary site IR-43 $(7.5 \mu \mathrm{g} / \mathrm{L})$ was lower than other tributary or main-stem sites. The highest median selenium concentration $(18.9 \mu \mathrm{g} / \mathrm{L})$ was measured in the La Junta WWTP effluent (fig. 25A). Patterson Hollow had the largest interquartile range of dissolved selenium concentrations, which indicates high variability in sample concentrations. No concentrations of dissolved selenium for any of the sampled sites exceeded the USEPA primary drinking-water standard of $50 \mu \mathrm{g} / \mathrm{L}$ (U.S. Environmental Protection Agency, 2011). The origin of the selenium is likely geologic, as summarized by Miller and others (2010), and associated with groundwater or irrigation recharge coming in contact with the Cretaceous-age marine Pierre Shale and Niobrara Formation. 


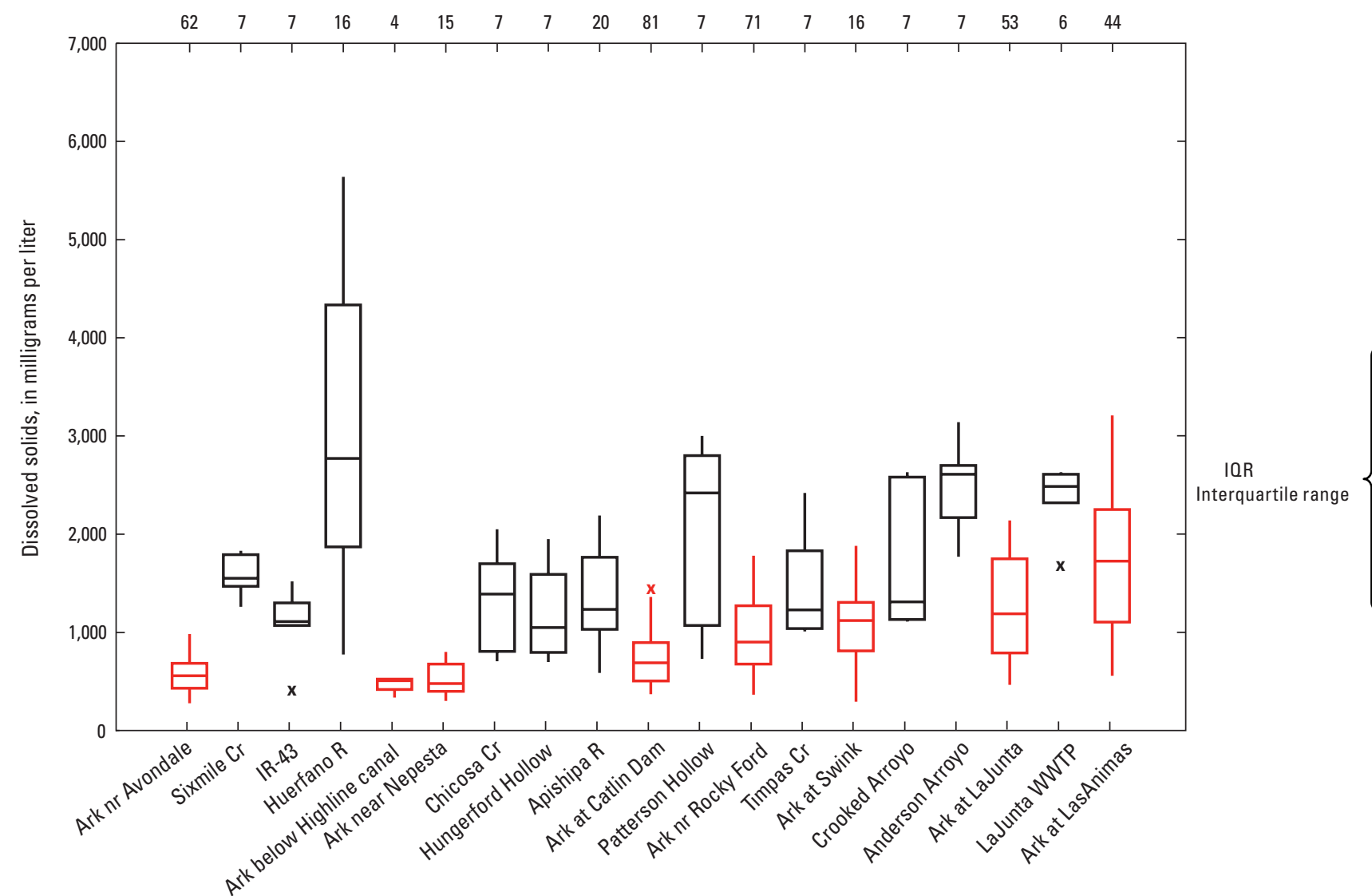

\section{EXPLANATION}

$10 \longleftarrow$ Number of samples

Outside value

(greater than 1.5 times the IOR)

$\longleftarrow$ Upper tail

(less than or equal to 1.5 times the IOR)

$\longleftarrow$ 75th percentile

50th percentile

(median or middle value)

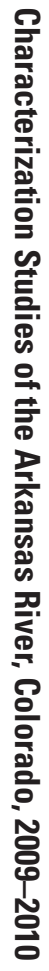

$\longleftarrow$ 25th percentile

$\leftarrow$ Lower tail

(less than or equal to 1.5 times the IOR)

Main-stem site boxplots in red

Figure 22. Comparison of dissolved-solids concentrations in the Arkansas River and selected tributaries from Avondale to Las Animas, $1990-2010$. 
Table 13. Regression equations relating concentrations of dissolved solids and specific conductance in the Lower Arkansas River and selected tributaries from Avondale to Las Animas, 2009-2010.

[Complete site names given in table 1; DS, dissolved solids, in milligrams per liter; SC, specific conductance, in microsiemens per centimeter at 25 degrees Celsius; $\mathrm{r}^{2}$, coefficient of determination]

\begin{tabular}{llcc}
\hline \multicolumn{1}{c}{ Site name } & \multicolumn{1}{c}{ Equation } & Number of comparisons & $\mathbf{r}^{2}$ \\
\hline Ark nr Avondale & DS $=0.71 \mathrm{SC}-35$ & 13 & 0.979 \\
Sixmile Cr & DS $=0.99 \mathrm{SC}-251$ & 7 & 0.968 \\
IR-43 & DS $=0.88 \mathrm{SC}-135$ & 7 & 0.998 \\
Huerfano R & DS $=1.08 \mathrm{SC}-577$ & 5 & 0.995 \\
Ark blw Highline Canal & DS $=0.77 \mathrm{SC}-72$ & 4 & 0.957 \\
Ark nr Nepesta & DS $=0.76 \mathrm{SC}-63$ & 15 & 0.988 \\
Chicosa Cr & DS $=0.95 \mathrm{SC}-240$ & 7 & 0.997 \\
Hungerford Hollow & DS $=0.98 \mathrm{SC}-357$ & 7 & 0.983 \\
Apishipa R & $\mathrm{DS}=1.04 \mathrm{SC}-400$ & 7 & 0.939 \\
Ark at Catlin Dam & $\mathrm{DS}=0.86 \mathrm{SC}-138$ & 14 & 0.983 \\
Patterson Hollow & $\mathrm{DS}=0.90 \mathrm{SC}-151$ & 7 & 0.961 \\
Ark nr Rocky Ford & $\mathrm{DS}=0.86 \mathrm{SC}-133$ & 28 & 0.989 \\
Timpas Cr & $\mathrm{DS}=1.07 \mathrm{SC}-436$ & 7 & 0.999 \\
Ark at Swink & $\mathrm{DS}=0.88 \mathrm{SC}-142$ & 16 & 0.986 \\
Crooked Arroyo & $\mathrm{DS}=1.08 \mathrm{SC}-435$ & 7 & 0.999 \\
Anderson Arroyo & $\mathrm{DS}=1.04 \mathrm{SC}-415$ & 7 & 0.996 \\
Ark at La Junta & $\mathrm{DS}=0.88 \mathrm{SC}-149$ & 16 & 0.992 \\
\hline
\end{tabular}

Concentrations of dissolved uranium in water samples from the LARB increase in the Arkansas River with distance downstream from Ark nr Avondale to Ark at Las Animas (fig. 3), with median concentrations ranging from 6.1 to 27.4 $\mu \mathrm{g} / \mathrm{L}$ (fig. 25B). The median uranium concentration $(39 \mu \mathrm{g} / \mathrm{L})$ in Sixmile $\mathrm{Cr}$ exceeded the USEPA drinking-water standard $(30 \mu \mathrm{g} / \mathrm{L})$ (U.S. Environmental Protection Agency, 2011). Sixmile $\mathrm{Cr}$ also had the highest median uranium concentration. The tributaries Sixmile Cr, IR-43, Huerfano R, and Chicosa Cr all drain the lower part of the Cretaceous-age Pierre Shale and upper part of the Niobrara Formation, which are thought to be geologic sources of uranium (Landis, 1959; Miller and others, 2010). Two samples from Patterson Hollow exceeded the USEPA drinking-water standard for uranium - one collected in November 2009 and the other in June 2010. One sample from Timpas $\mathrm{Cr}$ and one from Crooked Arroyo, both collected in the fall when streamflow was low, exceeded the USEPA drinkingwater standard. Patterson Hollow, Timpas $\mathrm{Cr}$, and Crooked Arroyo basins are underlain by the upper part of the Niobrara Formation.

Regression analysis of dissolved selenium and dissolved uranium concentrations, as in the UARB, showed some correlation with SC, DS, and streamflow (figs. $26 A$ and $B$ ). Selenium in the main-stem samples from Ark nr Avondale to Ark at Las Animas is weakly correlated with SC $\left(\mathrm{r}^{2}=0.42\right)$ and DS $\left(r^{2}=0.50\right)$ (fig. 26A). However, uranium shows a strong correlation to SC and DS, with a linear regression $\mathrm{r}^{2}$ of 0.86 and 0.92 respectively (fig. $26 B$ ), suggesting that uranium concentrations can be reasonably estimated from either SC or DS.

Both dissolved selenium and uranium concentrations in samples from main-stem LARB sites (2009 to 2010) decrease with increasing streamflow (fig. 27); however, uranium concentrations $\left(r^{2}=0.53\right)$ show a moderate correlation with streamflow. As in the UARB, it can be suggested from the selenium-flow and uranium-flow relations that groundwater may be the main source of these constituents to the Arkansas River rather than main-stem or tributary surface-water runoff at lower streamflows. The increased surface-water flow in the Arkansas River may dilute selenium and uranium concentrations of groundwater inflows and (or) impede groundwater inflow containing dissolved selenium and uranium. However, data pertaining to groundwater and groundwater surface-water interaction in the LARB are insufficient to confirm this. 

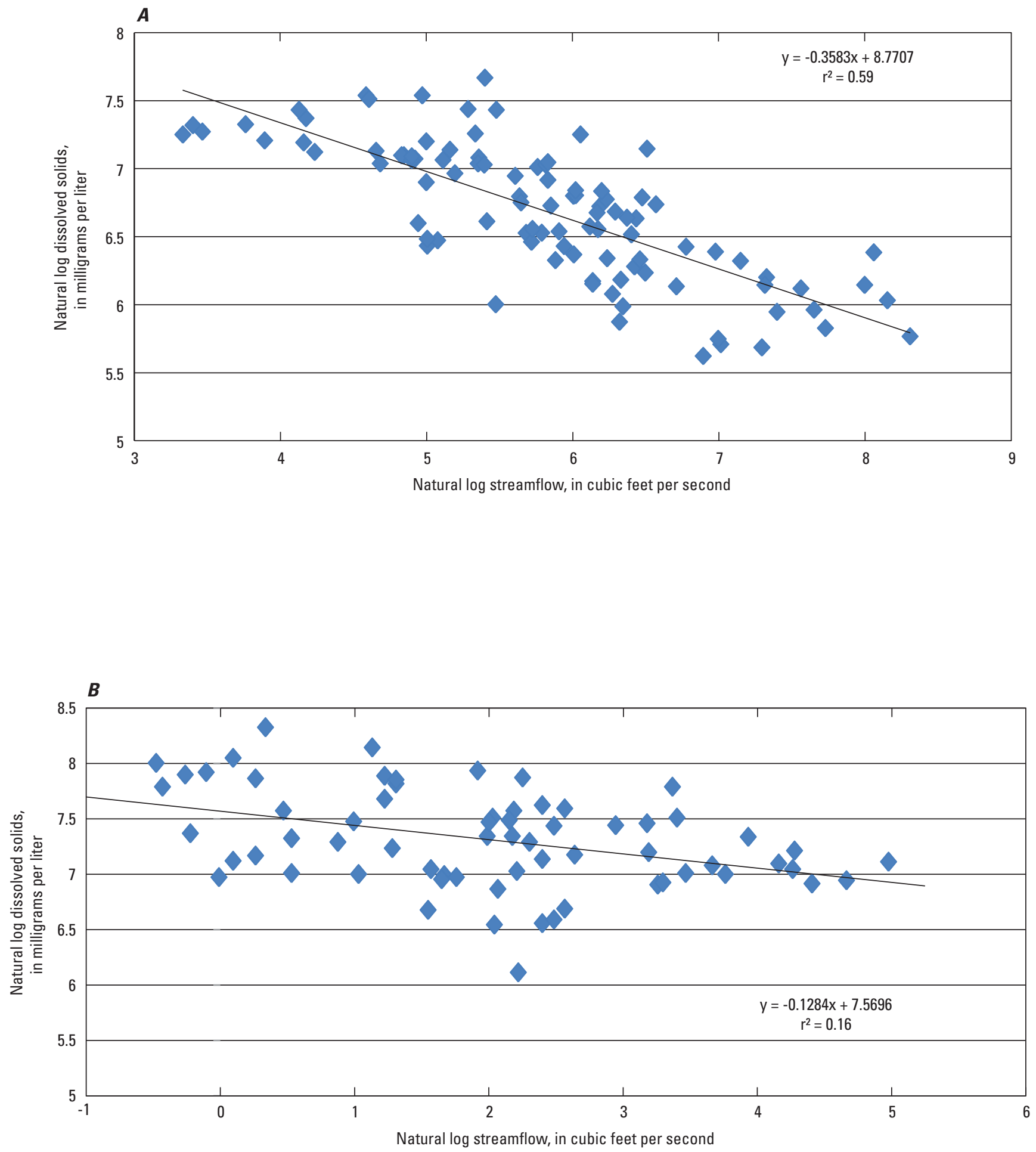

Figure 23. Concentrations of dissolved solids and streamflow in the Arkansas River $(A)$ and selected tributaries $(B)$ from Avondale to Las Animas, 2009-2010. 

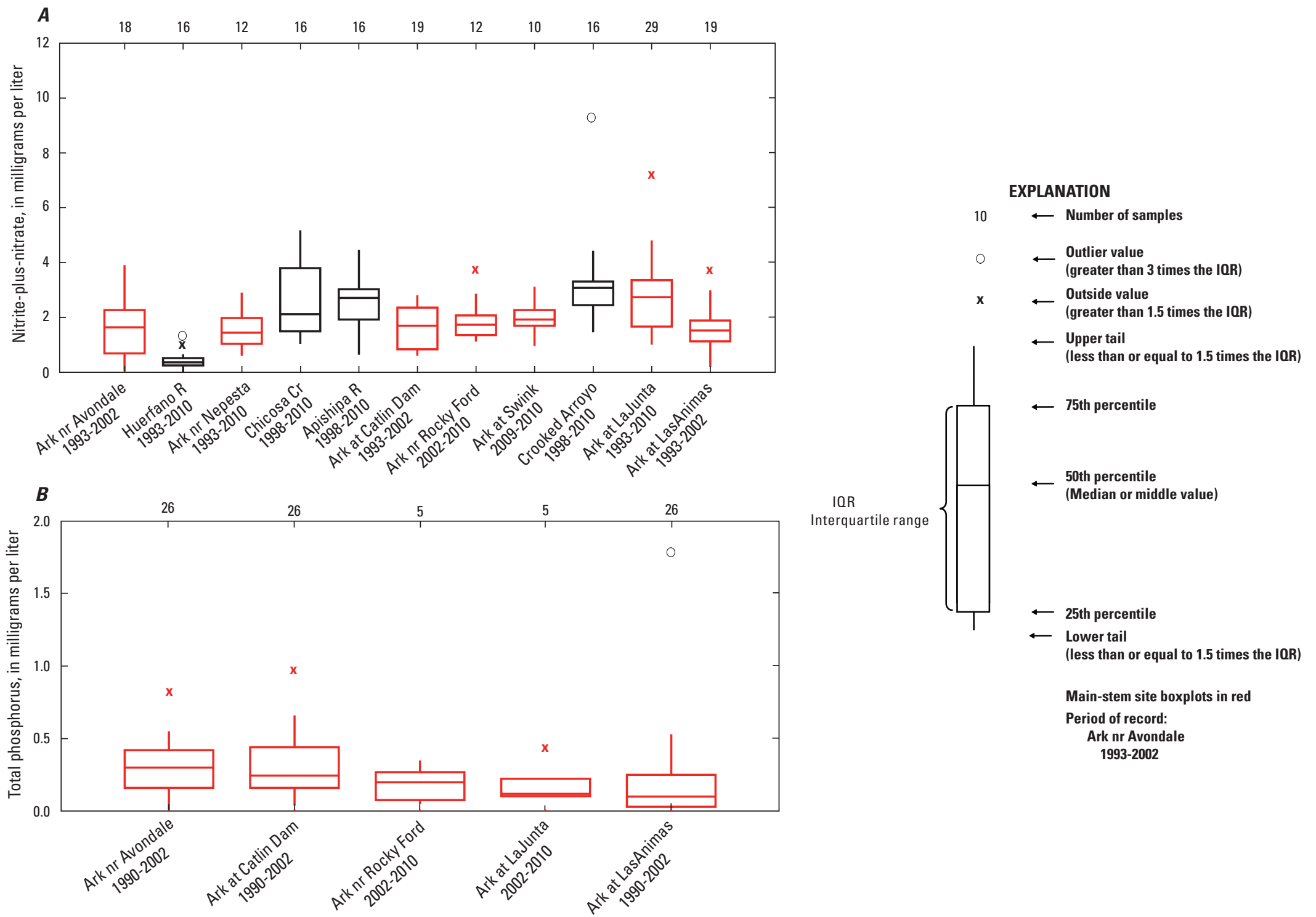

Figure 24. Comparison of concentrations of $(A)$ nitrite-plus-nitrate and $(B)$ total phosphorus in the Arkansas River from Avondale to Las Animas, $1990-2010$. 

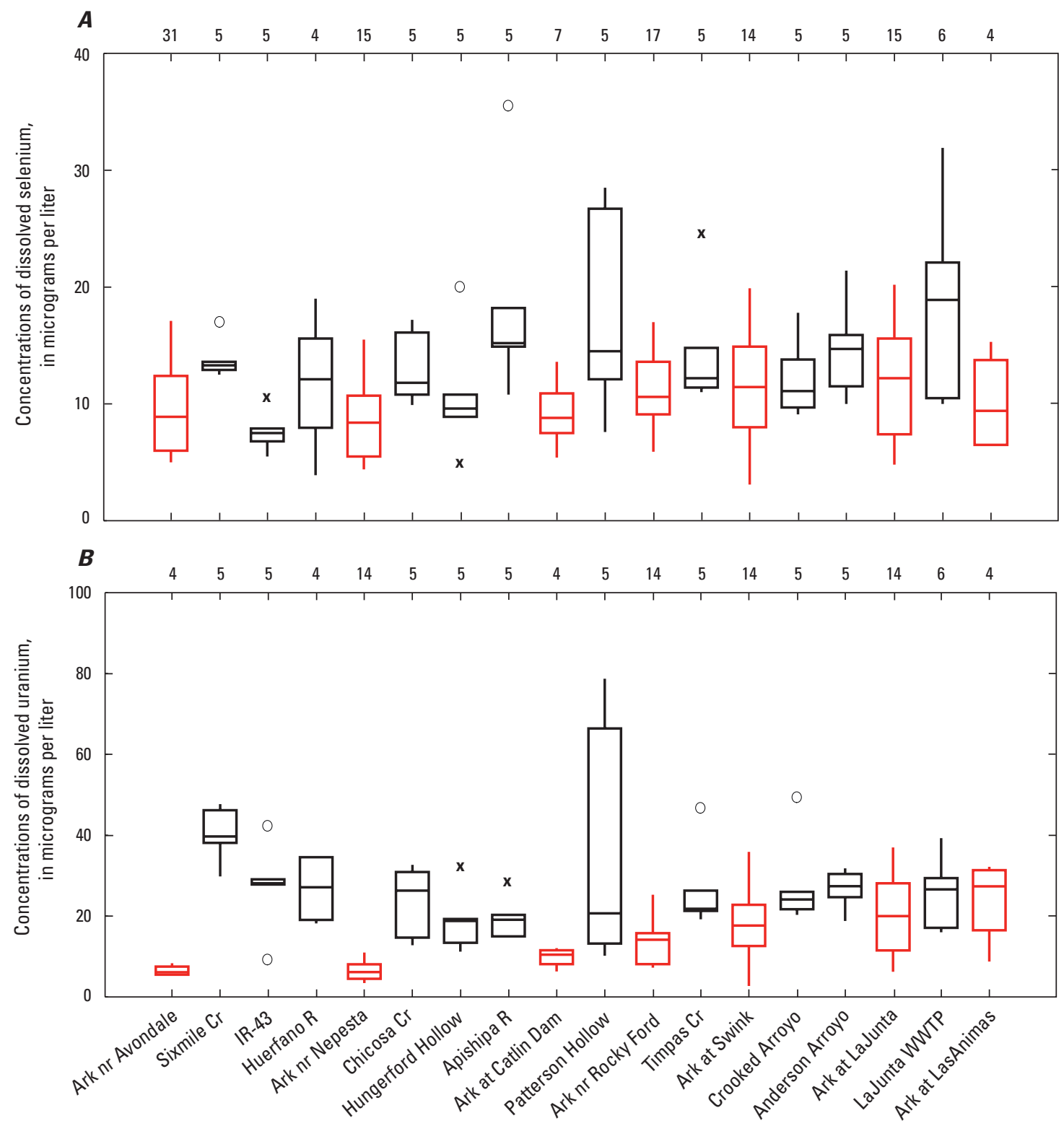

- 25th percentile

(less than or equal to 1.5 times the IOR) Main-stem site boxplots in red

Figure 25. Comparison of concentrations of $(A)$ dissolved selenium and $(B)$ dissolved uranium in the Arkansas River from Avondale to Las Animas, $2009-2010$. 

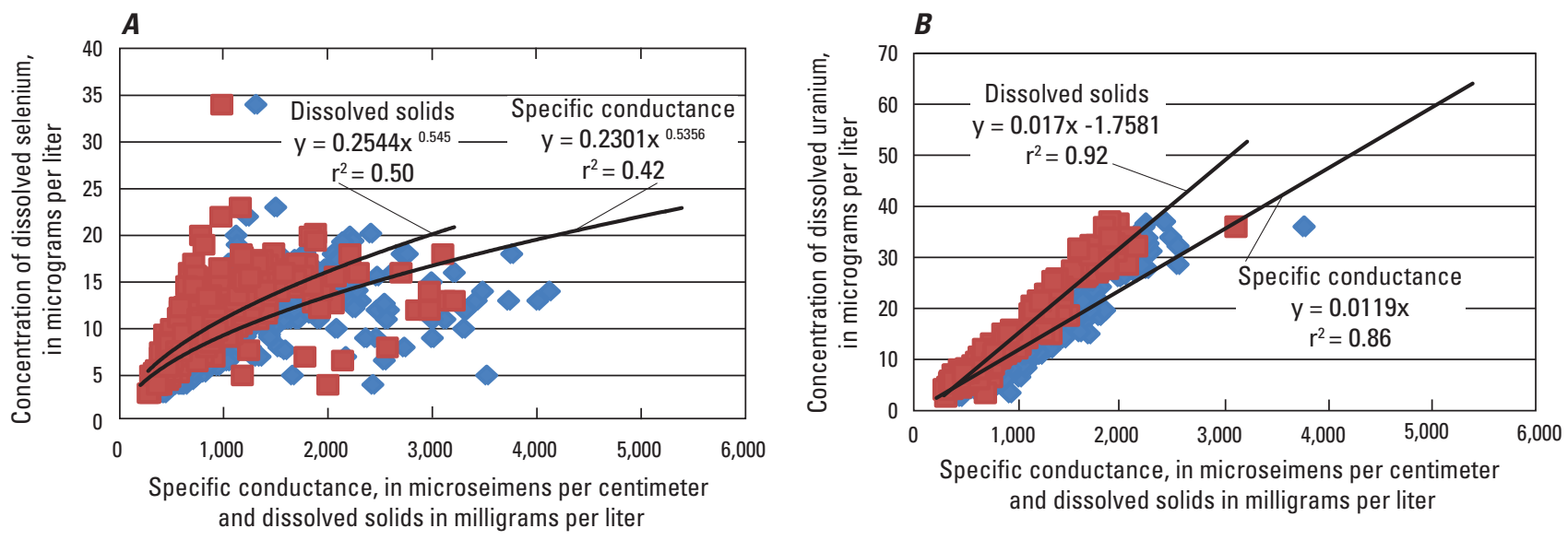

Figure 26. Relation of concentrations of $(A)$ dissolved selenium and $(B)$ dissolved uranium with specific conductance and dissolved solids in the Arkansas River from Avondale to Las Animas, 1990-2010.

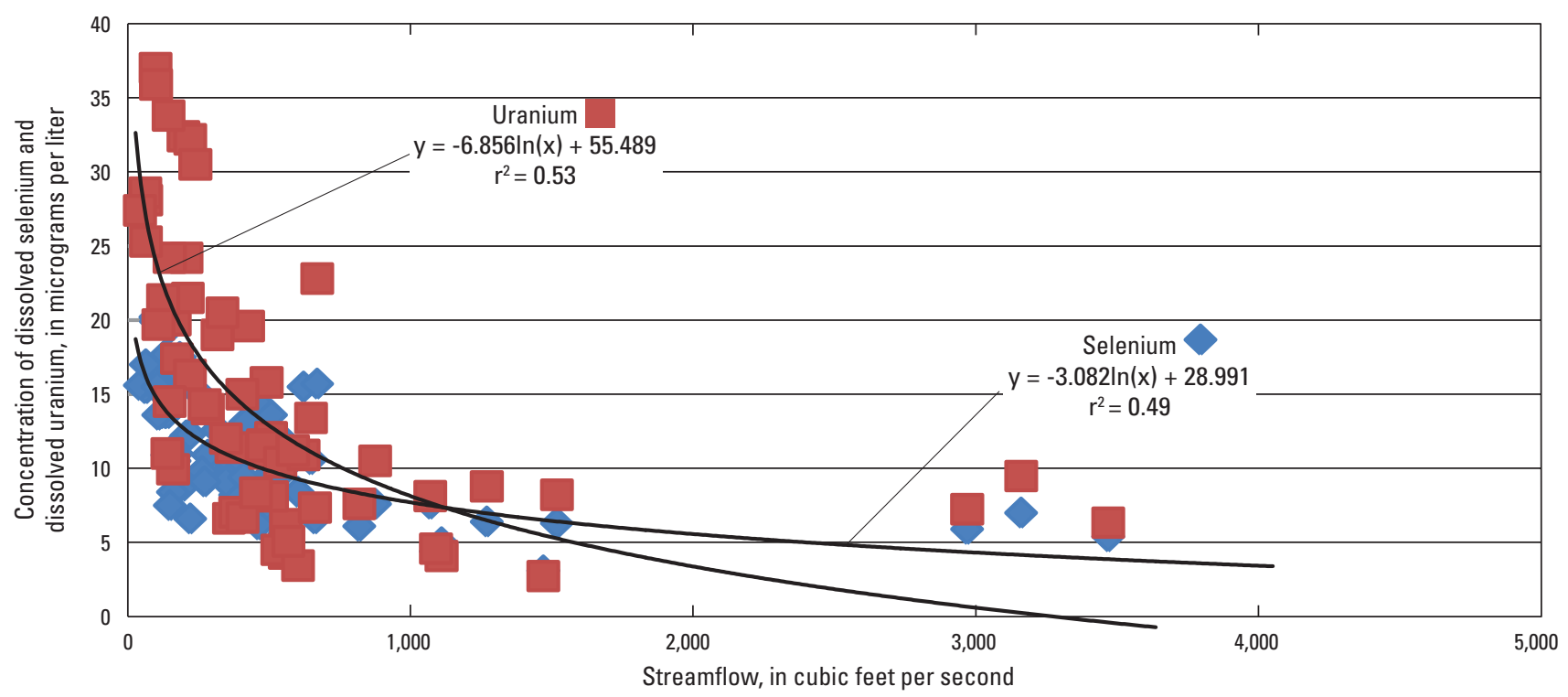

Figure 27. Relation of concentrations of dissolved selenium and dissolved uranium with streamflow in the Arkansas River from Avondale to Las Animas, 2009-2010.

\section{Hydrogen and Oxygen Isotopes}

Values of $\delta \mathrm{D}$ and $\delta^{18} \mathrm{O}$ for samples of water collected from main-stem sites in the LARB show a linear trend that plots below the GMWL (line slope of 8 ) and the Colorado LMWL (line slope of 6.3) (fig. 28A). These results indicate isotopic enrichment of $\delta \mathrm{D}$ and $\delta^{18} \mathrm{O}$ for these samples through evaporation and possibly evapotranspiration. The main-stem samples collected in early June 2010 are the most isotopically light samples in comparison to other samples collected at the same sites in other months; however, the main-stem samples for June are not isotopically similar to the Lake $\mathrm{Cr}$ snowmelt sample $\left(\delta \mathrm{D}=-126\right.$ per mil and $\mathrm{d}^{18} \mathrm{O}=-17$ per mil). The water collected in June 2010 likely has been affected by evaporation and may be representative of water released from Pueblo Reservoir. The LARB main-stem samples from October and November 2009 and August 2010 plot (fig. 28A) with no clear temporal groupings such as those in the UARB. Samples from Ark at Las Animas, the most downstream site in the LARB, are the most isotopically heavy, suggesting possible increased surface-water evaporation and (or) increasing contribution of groundwater that has been affected by evaporation and irrigation recharge.

Most of the tributary samples and samples from the La Junta WWTP plot (fig. 28B) below the GMWL and the Colorado LMWL, indicating enrichment in $\delta \mathrm{D}$ and $\delta^{18} \mathrm{O}$, probably as a result of evaporation. A regression line calculated for 

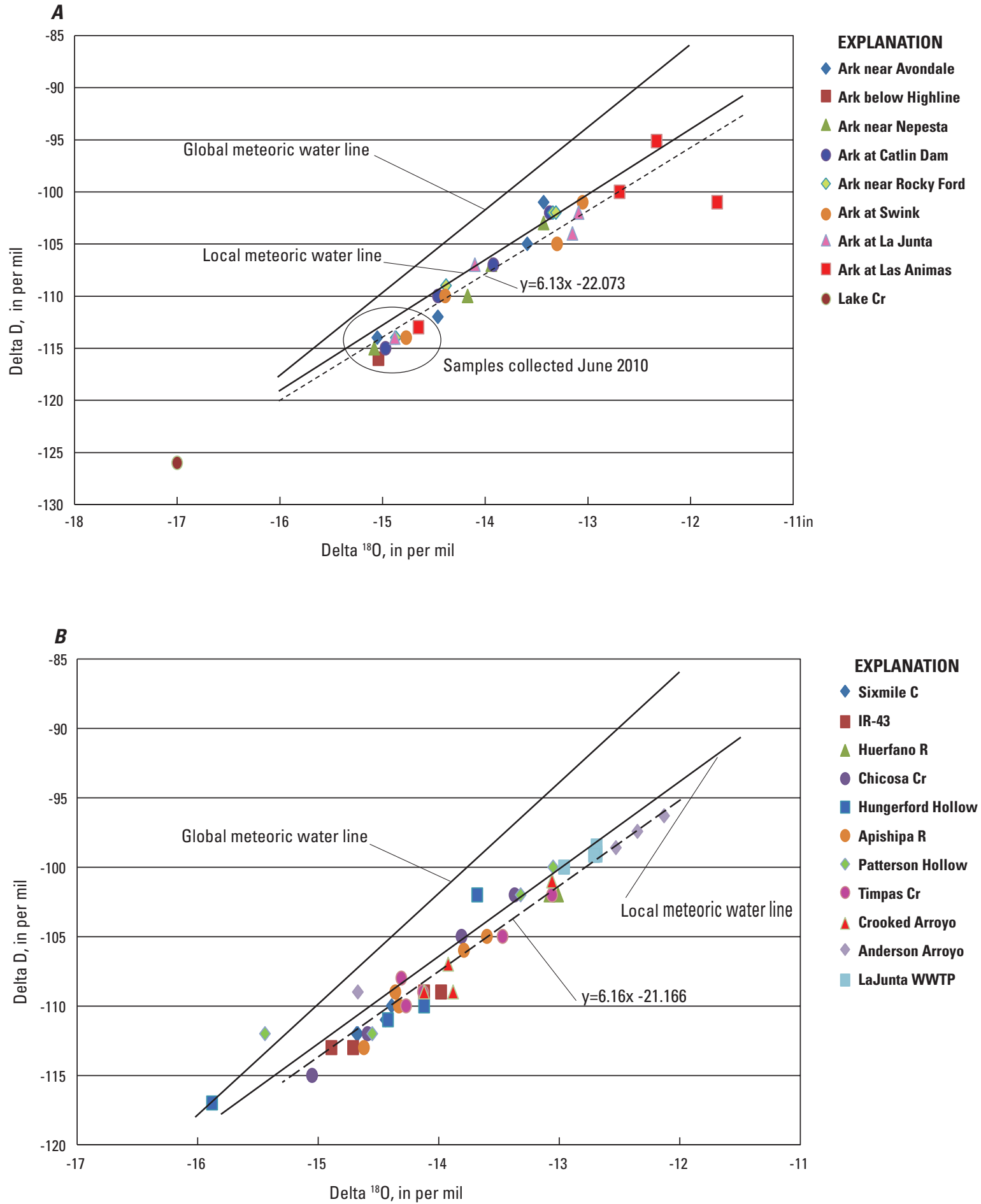

Figure 28. Delta $D$ and delta ${ }^{18} O$ in samples from $(A)$ main-stem sites on the Arkansas River from Avondale to Las Animas and (B) selected tributaries, 2009-2010. 
the tributary samples is similar to the main-stem line (slope of 6.16). Isotope ratios from Sixmile Cr, IR-43, Huerfano R, Crooked Arroyo, and La Junta WWTP group with little or no temporal variation (within 1 per mil unit), which suggests the source water for these tributaries does not undergo numerous evaporation cycles through irrigation return and reuse. The remaining sampled tributaries have greater temporal variation in isotopic ratios suggesting multiple evaporation cycles or, as for the main-stem sites, possibly increasing contribution of groundwater that has been affected by evaporation and irrigation recharge. However, as in the UARB, no LARB groundwater isotope samples are available for comparison to the surface-water samples. Finally, samples collected from Anderson Arroyo in October 2009 and Hungerford Hollow in November 2009 plot above the Colorado LMWL. A single sample from Patterson Hollow collected in October 2009 plots above the GMWL. In these samples, the $\delta \mathrm{D}$ and $\delta^{18} \mathrm{O}$ may have been affected by isotopically light water in runoff from localized storms.

\section{Characteristics of Instantaneous Dissolved Solids, Selenium, and Uranium Loading}

Characterization of loading in the LARB focused on the synoptic samples collected during low streamflow (November 16-19, 2009) when the influence from groundwater inflow to the river would likely be large (table 14). In the Arkansas River from Ark nr Avondale to Ark nr Nepesta, streamflow increased downstream; however, the contribution $\left(18.2 \mathrm{ft}^{3} / \mathrm{s}\right)$ from the measured tributaries (Huerfano R, IR-43, and Sixmile $\mathrm{Cr}$ ), does not account for all of the increase in streamflow at Ark nr Nepesta. This suggests a possible groundwater contribution in this reach that has not been measured. From Ark nr Nepesta to Ark at Catlin Dam, diversion of water through the Otero Canal (table 14) diverts $40 \mathrm{ft}^{3} / \mathrm{s}$ of the measured streamflow at Ark at Catlin Dam, whereas tributaries in this reach contribute $26.6 \mathrm{ft}^{3} / \mathrm{s}$ of the streamflow. The net decrease in streamflow (table 14) from Ark nr Nepesta to Ark at Catlin Dam may be attributed in part to the diversions to the Otero Canal. From Ark at Catlin Dam to Ark nr Rocky Ford, water removed from the Arkansas River through the Fort Lyon Storage Canal had the dominant effect on the total flow in the river. The canal (active in the months November to February) diverted $382 \mathrm{ft}^{3} / \mathrm{s}$ of the flow within the reach between Ark at Catlin Dam and Ark nr Rocky Ford, whereas Patterson Hollow contributed $0.62 \mathrm{ft}^{3} / \mathrm{s}$ to the flow at Ark nr Rocky Ford. Downstream from the Ft Lyon Storage Canal diversion, flows generally increased with distance downstream to Ark at Las Animas. Timpas Creek contributed approximately $29 \mathrm{ft}^{3} / \mathrm{s}$ of the flow at Ark at Swink. No diversions remove water in the reaches Ark at Swink to Ark at La Junta and Ark at La Junta to Ark at Las Animas (table 14); however, Crooked Arroyo and Anderson Arroyo contribute minor amounts of inflow $\left(10.6 \mathrm{ft}^{3} / \mathrm{s}\right)$ to the river at Ark at La Junta (table 14). For the synoptic event November 16-19, 2009, the La Junta WWTP contributed $1.97 \mathrm{ft}^{3} / \mathrm{s}$ to the streamflow at Ark at Las Animas, the only measured contribution in that reach. As in the other reaches of the LARB, the groundwater contribution was not measured but may be a source of streamflow in the reach from Ark at Swink to Ark at Las Animas.

Based on data collected November 16-19, 2009, in the LARB, DS loads followed a pattern similar to that of measured streamflow and increased in the Arkansas River from Ark nr Avondale to Ark at Catlin Dam (table 14). In the reach Ark nr Avondale to Ark nr Nepesta, the measured tributaries contributed 91.4 tons/d of DS load to the Arkansas River. In the reach Ark nr Nepesta to Ark at Catlin Dam, tributaries contributed 133.4 tons/d to the DS load, but the Otero Canal removed 93.9 tons/d. In the reach Ark at Catlin Dam to Ark nr Rocky Ford, DS loads decreased from 1,199.2 tons/d to 408.4 tons/d. The Fort Lyon Storage Canal diverts 841.6 tons/d, while tributaries contributed 5 tons/d of the DS load to Ark nr Rocky Ford (table 14). In the reach from Ark nr Rocky Ford to Ark at Swink, the DS load increased from 408.4 tons/d to 730.9 tons/d, the greatest increase in DS load (322.5 tons/d) for any of the study reaches (table 14). Timpas Cr, the only measured tributary in the Ark nr Rocky Ford to Ark at Swink reach, contributed 189.5 tons/d of the DS load at Ark at Swink. In the reaches Ark at Swink to Ark at La Junta, and Ark at La Junta to Ark at Las Animas, DS loads increased from 730.9 tons/d at Ark at Swink to 1,044.9 tons/d at Ark at Las Animas. Tributaries in the reach Ark at Swink to Ark at La Junta contributed 76.8 tons/d to the main-stem Arkansas River.

A Kruskall-Wallis test on periodic and synoptic DS loads in 2009-2010, excluding high streamflow samples collected in May, June, and July, indicated statistically significant (p-value 0.038 ) differences between DS loads at the main-stem sites. Using the Tukey's test for multiple comparisons, the significant differences between instantaneous DS loads at the mainstem sites were from Ark nr Rocky Ford to Ark at La Junta. Further investigation would be needed to evaluate potential dissolved-solids source areas within the Arkansas River from Ark nr Rocky Ford to Ark at La Junta.

For the reach from Ark nr Avondale to Ark nr Nepesta for the synoptic event of November 16-19, 2009, streamflow in the main-stem increased from $453 \mathrm{ft}^{3} / \mathrm{s}$ at Ark nr Avondale to $539 \mathrm{ft}^{3} / \mathrm{s}$ at Ark nr Nepesta (table 14). The measured contribution to streamflow from tributaries within the reach was $18.2 \mathrm{ft}^{3} / \mathrm{s}$. No diversions were present within the reach. Therefore, the ungaged streamflow within the reach was calculated to be $67.8 \mathrm{ft}^{3} / \mathrm{s}$. The DS load in the same reach increased from 876.9 tons/d at Ark nr Avondale to 1,164.2 tons/d at Ark $\mathrm{nr}$ Nepesta. The contribution to the DS load from tributaries was 91.4 tons/d. Therefore, the ungaged contribution to DS load within the reach was calculated to be 195.9 tons/d. Using the water balance method, as discussed in the section "Characteristics of Instantaneous Dissolved Solids, Selenium, and Uranium Loading" for the UARB, and substituting values for Ark nr Avondale to Ark nr Nepesta, and assuming a single ungaged source, the DS concentration of the single source (such as groundwater) is calculated to be $1,069 \mathrm{mg} / \mathrm{L}$. 
Table 14. Measured and calculated ungaged streamflow, contributions to dissolved-solids load, and dissolved-solids concentration for six reaches in the Lower Arkansas River Basin, November 16-19, 2009.

[Complete site names given in table 1; UC, ungaged contribution; negative numbers indicate a loss of water from the river; WWTP, wastewater treatment plant]

\begin{tabular}{|c|c|c|c|c|}
\hline Reach & $\begin{array}{c}\text { Site name or component } \\
\text { of flow }\end{array}$ & $\begin{array}{l}\text { Streamflow, in cubic } \\
\text { feet per second }\end{array}$ & $\begin{array}{l}\text { Dissolved solids concentra- } \\
\text { tion, in milligrams per liter }\end{array}$ & $\begin{array}{c}\text { Dissolved solids load, in } \\
\text { tons per day }\end{array}$ \\
\hline \multirow{4}{*}{ Reach 1} & Ark nr Avondale & 453 & 717 & 876.9 \\
\hline & Tributaries $^{2}$ & 18.2 & 5,300 & 91.4 \\
\hline & $\mathrm{UC}$ & 67.8 & $1,069^{1}$ & 195.9 \\
\hline & Ark nr Nepesta & 539 & 800 & $1,164.2$ \\
\hline \multirow{5}{*}{ Reach 2} & Ark nr Nepesta & 539 & 800 & $1,164.2$ \\
\hline & Tributaries $^{2}$ & 26.6 & 5,640 & 133.4 \\
\hline & Diversions & -40 & 869 & -93.9 \\
\hline & $\mathrm{UC}$ & -18.6 & $89.6^{1}$ & -4.5 \\
\hline & Ark at Catlin Dam & 507 & 876 & $1,199.2$ \\
\hline \multirow{5}{*}{ Reach 3} & Ark at Catlin Dam & 507 & 876 & $1,199.2$ \\
\hline & Tributaries $^{2}$ & 0.62 & 3,000 & 5.0 \\
\hline & Diversions & -382 & 816 & -841.6 \\
\hline & $\mathrm{UC}$ & -0.62 & NA & 45.8 \\
\hline & Ark nr Rocky Ford & 125 & 1,210 & 408.4 \\
\hline \multirow{4}{*}{ Reach 4} & Ark nr Rocky Ford & 125 & 1,210 & 408.4 \\
\hline & Tributaries $^{2}$ & 29 & 2,420 & 189.5 \\
\hline & $\mathrm{UC}$ & -10.0 & $4,926^{1}$ & 133.0 \\
\hline & Ark at Swink & 144 & 1,880 & 730.9 \\
\hline \multirow{4}{*}{ Reach 5} & Ark at Swink & 144 & 1,880 & 730.9 \\
\hline & Tributaries $^{2}$ & 10.6 & 5,770 & 76.8 \\
\hline & $\mathrm{UC}$ & 42.4 & $843^{1}$ & 96.5 \\
\hline & Ark at La Junta & 197 & 1,700 & 904.2 \\
\hline \multirow{4}{*}{ Reach 6} & Ark at La Junta & 197 & 1,700 & 904.2 \\
\hline & WWTP & 1.97 & NA & NA \\
\hline & $\mathrm{UC}$ & 30.03 & $1,725^{1}$ & 140.7 \\
\hline & Ark at Las Animas & 229 & 1,690 & $1,044.9$ \\
\hline
\end{tabular}

${ }^{1}$ Value is based on the assumption that the ungaged contribution (UC) is from a single source.

${ }^{2}$ Dissolved solids concentration summed for all tributaries in the reach.

For the reach from Ark nr Nepesta to Ark at Catlin Dam for the same synoptic event, the ungaged streamflow within the reach was calculated to be $-18.6 \mathrm{ft}^{3} / \mathrm{s}$ and the DS load was calculated to be 4.5 tons/d. A negative streamflow in this reach indicates that for the period evaluated, the Arkansas River within this reach is losing water to the aquifer, or inflows and loads from ungaged sources are smaller than discharge from the Arkansas River to the aquifer. For the ungaged streamflow and ungaged contribution to DS load, the DS concentration is calculated to be $89.6 \mathrm{mg} / \mathrm{L}$ (table 14).

For the reach from Ark at Catlin Dam to Ark nr Rocky Ford for the same synoptic event, the ungaged streamflow from contributions within the reach was calculated to be
$-0.62 \mathrm{ft}^{3} / \mathrm{s}$ and the DS load was calculated to be 45.8 tons/d (table 14). As in the reach from Ark nr Nepesta to Ark at Catlin Dam, a negative streamflow in this reach suggests the Arkansas is losing water to the local aquifer. The DS concentration for ungaged sources in the reach Ark at Catlin Dam to Ark nr Rocky Ford was not calculated because the of the small ungaged streamflow $\left(-0.62 \mathrm{ft}^{3} / \mathrm{s}\right)$.

For the reach from Ark nr Rocky Ford to Ark at Swink, the ungaged streamflow from contributions within the reach was calculated to be $-10 \mathrm{ft}^{3} / \mathrm{s}$, and the estimated DS load was calculated to be 133 tons/d. As in the reach from Ark nr Nepesta to Ark at Catlin Dam, a negative streamflow in this reach suggests the Arkansas is losing water to the local 
aquifer. For the ungaged streamflow and ungaged contributions to DS load, the DS concentration is calculated to be $4,926 \mathrm{mg} / \mathrm{L}$ (table 14). Substantial differences between DS concentration in the main stem and for the ungaged contributions could indicate unaccounted for inputs or losses in the reach or streamflow measurement error.

For the reach from Ark at Swink to Ark at La Junta, for November 16-19, 2009, the ungaged streamflow from losses within the reach were calculated to be $42.4 \mathrm{ft}^{3} / \mathrm{s}$ and ungaged contributions to DS load was 96.5 tons/d. Assuming a single source, such as groundwater discharge, for the ungaged streamflow and ungaged contributions to DS load, the DS concentration of the ungaged single source is calculated to be $843 \mathrm{mg} / \mathrm{L}$ (table 14).

For the reach from Ark at La Junta to Ark at Las Animas, for the same synoptic event, the ungaged streamflow within the reach was calculated to be $30 \mathrm{ft}^{3} / \mathrm{s}$ and DS load was 140.7 tons/d. Assuming an ungaged single source for the DS load, for the ungaged streamflow and ungaged contributions to DS load, the DS concentration of the single ungaged source is calculated to be $1,725 \mathrm{mg} / \mathrm{L}$. The ungaged streamflow, ungaged contributions to DS load, and calculated DS concentration for an assumed ungaged single source for all six reaches in the LARB are applicable only for November 16-19, 2009 , and may likely vary throughout the year for different streamflow and water-quality conditions.

The Quaternary alluvial deposits in the LARB are reported to have a median DS concentration of $1,700 \mathrm{mg} / \mathrm{L}$, and concentrations range from approximately 150 to 7,000 $\mathrm{mg} / \mathrm{L}$ (Miller and others, 2010). The DS concentrations of ungaged sources for each of the reaches in the LARB fall within the reported range of groundwater DS concentrations, and groundwater is a plausible source for the estimated DS load. In addition to groundwater, ungaged irrigation return flow and tributaries may also be sources of the DS load; however, proportions of contributions, as in the UARB, from these sources are unknown.

Selenium loads on November 16-19, 2009, in the LARB for main-stem sites increased from Ark at Avondale to Ark at Catlin (table 15), but loads decreased substantially from Ark at Catlin Dam to Ark nr Rocky Ford. Selenium loads increased again from Ark nr Rocky Ford to Ark at Las Animas. The Fort Lyon Storage Canal diverts $25.6 \mathrm{lbs} / \mathrm{d}$ of the selenium load from downstream of Ark at Catlin Dam removing the selenium from the Arkansas River. No selenium load contribution was calculated for the La Junta WWTP as no selenium samples were collected for this synoptic event.

Table 15. Change in streamflow and loads of dissolved solids, selenium, and uranium between main-stem sites in the Lower Arkansas River Basin, November 16-19, 2009.

[Complete site names given in table 1]

\begin{tabular}{|c|c|c|c|c|c|c|}
\hline \multirow{2}{*}{ Site name } & \multirow{2}{*}{$\begin{array}{c}\text { Streamflow, } \\
\text { in cubic feet } \\
\text { per second }\end{array}$} & \multicolumn{2}{|c|}{ Percent change } & \multirow{2}{*}{$\begin{array}{c}\text { Dissolved } \\
\text { solids load, } \\
\text { in tons per } \\
\text { day }\end{array}$} & \multicolumn{2}{|c|}{ Percent change } \\
\hline & & $\begin{array}{l}\text { Within } \\
\text { reach }\end{array}$ & Cumulative & & $\begin{array}{l}\text { Within } \\
\text { reach }\end{array}$ & Cumulative \\
\hline Ark nr Avondale & 453 & & & 876.9 & & \\
\hline Ark nr Nepesta & 539 & 19 & 19 & 1164.2 & 33 & 33 \\
\hline Ark at Catlin Dam & 507 & -6 & 12 & 1199.2 & 3 & 37 \\
\hline Ark nr Rocky Ford & 125 & -75 & -72 & 408.4 & -66 & -53 \\
\hline Ark at Swink & 144 & 15 & -68 & 730.9 & 79 & -17 \\
\hline Ark at La Junta & 197 & 37 & -57 & 904.2 & 24 & 3 \\
\hline Ark at Las Animas & 229 & 16 & -49 & 1044.9 & 16 & 19 \\
\hline \multirow{2}{*}{ Site name } & \multirow{2}{*}{$\begin{array}{c}\text { Selenium load, } \\
\text { in pounds per } \\
\text { day }\end{array}$} & \multicolumn{2}{|c|}{ Percent change } & $\begin{array}{l}\text { Uranium } \\
\text { load, in }\end{array}$ & \multicolumn{2}{|c|}{ Percent change } \\
\hline & & $\begin{array}{l}\text { Within } \\
\text { reach }\end{array}$ & Cumulative & $\begin{array}{c}\text { pounds per } \\
\text { day }\end{array}$ & $\begin{array}{l}\text { Within } \\
\text { reach }\end{array}$ & Cumulative \\
\hline Ark nr Avondale & 35.5 & & & 20.4 & & \\
\hline Ark nr Nepesta & 35.2 & -1 & -1 & 30.3 & 49 & 49 \\
\hline Ark at Catlin Dam & 38.8 & 10 & 9 & 34.5 & 14 & 69 \\
\hline Ark nr Rocky Ford & 10.1 & -74 & -72 & 14.4 & -58 & -29 \\
\hline Ark at Swink & 15.1 & 50 & -57 & 26.3 & 83 & 29 \\
\hline Ark at La Junta & 17.2 & 14 & -52 & 32.7 & 24 & 60 \\
\hline Ark at Las Animas & 18.9 & 10 & -47 & 37.7 & 15 & 85 \\
\hline
\end{tabular}


A Kruskall-Wallis test on selenium loads from samples collected during low-flow periods for this study from 20092010 indicated statistically significant (p-value 0.0036 ) differences between loads at the main-stem sites. Using the Tukey's test for multiple comparisons, the differences between the sites were statistically significant for Ark nr Nepesta to Ark at La Junta.

Uranium loads during November 16-19, 2009, increased in main-stem sites from Ark at Avondale to Ark at Catlin Dam (table 15), but loads decreased substantially from Ark at Catlin Dam to Ark nr Rocky Ford. Uranium loads increased again from Ark nr Rocky Ford to Ark at Las Animas. The Fort Lyon Storage Canal diverts $24.3 \mathrm{lbs} / \mathrm{d}$ of the uranium load from downstream of Ark at Catlin Dam removing the uranium from the Arkansas River. No uranium load contribution was calculated for the La Junta WWTP as no uranium samples were collected for this synoptic event.

A Kruskall-Wallis test on uranium loads from low-flow samples collected for this study from 2009-2010, indicated statistically significant ( $p$-value 0.048 ) differences between loads at the main-stem sites. Using the Tukey's test for multiple comparisons, the differences between the sites are significant, as with selenium, for Ark nr Nepesta to Ark at La Junta. The river reaches from Ark nr Nepesta to Ark at La Junta are potential source areas of selenium and uranium. Further investigation would be needed to describe the source or sources in greater detail.

\section{Summary}

As a result of continued water-quality concerns in the Arkansas River, including metal contamination from historical mining practices, potential effects associated with storage and movement of water, point- and nonpoint-source contamination, population growth, storm-water flows, and future changes in land and water use, the Arkansas River Basin Regional Resource Planning Group (RRPG) developed a strategy to address these issues. As such, a cooperative strategic approach to address the multiple water-quality concerns within selected reaches of the Arkansas River was developed to (1) identify stream reaches where stream-aquifer interactions have a pronounced effect on water quality and (or) where reactive transport, and physical and (or) chemical alteration of flow during conveyance is occurring, (2) quantify loading from point sources, and (3) determine source areas and mass loading for selected constituents.

To date in the Arkansas River Basin, most existing water-quality data have been collected for the purposes of characterizing current water-quality conditions for selected river reaches as they pertain to in-stream classifications and standards or had not been collected in a manner that allows for rigorous and accurate analysis of mass loading. Poor understanding of streamflow from ungaged tributary and return flows frequently result in poorly defined water budgets that are the basis for determining source contributions. The purpose of this report is to characterize streamflow and water-quality data collected along the selected reaches of the Arkansas River from Canon City to near Portland (Upper Arkansas River Basin (UARB)) and from Avondale to Las Animas (Lower Arkansas River Basin (LARB)) during 2009 and 2010, identify critical stream reaches where stream-aquifer interactions may potentially have a pronounced effect on water quality (or where point-source discharges are a significant load to the stream), and to identify potential load source areas for selected constituents within the UARB and LARB study reaches.

Data-collection activities were conducted for 2 years in the UARB and LARB. Water-quality samples were collected from June through December 2009 and from May through October 2010. In each study area, samples were collected periodically to characterize the water quality throughout the various hydrologic conditions observed in the Arkansas River Basin. Additionally, a limited number of synoptic (time-oftravel) sampling events were conducted to provide a better understanding of the in-stream water-quality processes using mass-loading analyses.

In the UARB, major-ion water-quality analyses indicate water from main-stem sites beginning at Canon City are a calcium-magnesium-bicarbonate water type and transition downstream to a calcium-magnesium-sulfate water type at the Arkansas River near Portland site. Changes in water type are likely due to changes in geology from igneous and metamorphic to sedimentary bedrock and the chemical composition of the various bedrocks within the basin with distance downstream.

Main-stem dissolved solids (DS) (salinity) median concentrations increase downstream in the Arkansas River from Canon City (153 milligram per liter $(\mathrm{mg} / \mathrm{L}))$ to near Portland $(264 \mathrm{mg} / \mathrm{L})$. Median DS concentrations in tributaries range from a low of $213 \mathrm{mg} / \mathrm{L}$ in the Oak Creek tributary to a high of $6,305 \mathrm{mg} / \mathrm{L}$ in water sampled from Arkansas River tributary 1 at CR 112 (Ark trib 1 at CR 112). In addition to irrigation return flows, inflows from groundwater may contribute to the high DS concentrations in the tributaries, especially those tributaries below Arkansas River tributary 2 at CR 119 (Ark trib 2 at CR 119) in Florence, Colorado, and those that drain the Penrose, Colorado, area where hay, pasture, orchard, and cropland acres are irrigated. The higher DS concentrations downstream from Florence can be attributed to differences in geology and variation in the chemical composition of the bedrock.

Concentrations of dissolved selenium and dissolved uranium increase in water samples downstream from Canon City to near Portland. One concentration of selenium in a sample from Bear Creek and concentrations of uranium in samples from Bear, Hardscrabble, and Ranger Creeks and Brush Hollow equaled or exceeded U.S. Environmental Protection Agency (USEPA) drinking-water standards (50 and $30 \mu \mathrm{g} / \mathrm{L}$, respectively) for those elements.

Hydrogen $(\delta \mathrm{D})$ and oxygen $\left(\delta^{18} \mathrm{O}\right)$ isotope ratios in samples from main-stem and tributary waters for the Arkansas 
River have a linear trend; however, most samples plot below the global meteoric water line (GMWL). The samples have a slope similar to the Colorado local meteoric water line (LMWL) of 6.3. Arkansas River main-stem and some tributary samples can be grouped into three sets of samples showing temporal variability. The first set are main-stem and tributary samples were collected in May 2010; Chandler, Oak, and Lake Creeks are the most isotopically light samples, suggesting that the water has not been affected by evaporation. An isotope sample was collected at Lake Creek near the headwaters of the Arkansas River as a background site for snowmelt and plots within this group, indicating that precipitation is the source for this water. The next grouping of samples includes main-stem samples collected in June, July and August and the tributary sample from Oak Creek. The isotopically heaviest group of samples includes those collected from Beaver, Ranger, and Bear Creeks and Brush Hollow, indicating water from these tributaries has been substantially affected by or contains greater amounts of irrigation return flows than Fourmile Creek, Hardscrabble Creek, Arkansas River tributary 1 at CR119, Ark trib 2 at CR119, and Ark trib1 at CR112. Evaporation, decreasing snowmelt runoff, and possible increasing contribution of groundwater that may contain isotopically heavier (more $\delta \mathrm{D}$ and $\delta^{18} \mathrm{O}$ ) water originating from irrigation recharge may explain the progression of Arkansas River main-stem isotope-light samples in May to heavier samples in August. No groundwater isotope samples have been collected in this area of the Arkansas River Basin, however, to compare to surface-water isotope samples.

There were statistical differences between the DS loads in the Arkansas River during low-streamflow conditions in 2009-2010. The groundwater DS load contribution to the water quality of the Arkansas River may be small in relation to the surface-water contribution during high-flow periods, and removing the high-flow samples from the data set allows for the groundwater contribution to be accounted for in the statistical analysis. Using the Tukey's test for multiple comparisons to determine which sites were different from each other resulted in showing statistically significant differences between instantaneous DS loads for sites Arkansas River at Canon City to Arkansas River at Portland. The same sites were significant for selenium loads. The river section from Arkansas River at Canon City to Arkansas River at Portland is a potential source area of dissolved solids and selenium to the UARB. No statistically significant difference between sites was determined for uranium loads.

To estimate the amount of ungaged contribution to DS loads from ungaged flows and other sources, the water balance for the synoptic on September 15, 2010, was used as the basis for calculating the concentration of DS from the ungaged sources. Calculated DS concentrations from ungaged sources for the UARB were Arkansas River at Canon City to Arkansas River near Canon City, 500.4 mg/L; Arkansas River near Canon City to Arkansas River at Portland, $706.8 \mathrm{mg} / \mathrm{L}$; and Arkansas River at Portland to Arkansas River near Portland, $191 \mathrm{mg} / \mathrm{L}$. The calculated DS concentrations for each of the reaches in the UARB fall within the reported range of groundwater DS concentrations, and groundwater is a plausible source for the ungaged contribution to the DS load. In addition to groundwater, ungaged irrigation return flow and tributaries may also be sources of the DS load; however, proportions of contributions from these sources is unknown. The ungaged contributions to DS load, ungaged streamflow, and calculated DS concentration are only for the synoptic samples collected in September, 2010, and may likely vary throughout the year for different streamflow and water-quality conditions.

Major-ion water-quality analyses indicate water from main-stem sites in the LARB beginning at Avondale are a calcium-magnesium-sulfate type, and sulfate becomes the more dominant cation downstream. The LARB main-stem DS median concentrations increase downstream from Avondale $(557 \mathrm{mg} / \mathrm{L})$ to Las Animas $(1,725 \mathrm{mg} / \mathrm{L})$. Median DS concentrations in tributaries and the La Junta wastewater treatment plant (WWTP) range from $1,050 \mathrm{mg} / \mathrm{L}$ in Hungerford Hollow to $2,770 \mathrm{mg} / \mathrm{L}$ in water sampled from the Huerfano River. As in the UARB, irrigation return flows and inflows from groundwater likely contribute to the high DS concentrations in all the tributaries, whereas differences in DS concentration ranges between the selected tributaries can be attributed to differences in geology and the chemical composition of the bedrock.

Median dissolved selenium concentrations vary in the main-stem sites and ranged from 8.4 to $12.2 \mu \mathrm{g} / \mathrm{L}$ in Arkansas River near Avondale to Arkansas River at Las Animas, and selenium concentrations increase downstream at sites from Arkansas River near Nepesta to Arkansas River at La Junta. Median selenium concentrations measured in tributaries generally were higher than those in the main-stem sites; however, no concentrations of selenium in any of the sampled sites exceeded USEPA primary drinking-water standards. The median dissolved uranium concentration $(39 \mu \mathrm{g} / \mathrm{L})$ in Sixmile Creek exceeded the USEPA drinking-water standard. The tributaries, Sixmile Creek, IR-43, Huerfano River, and Chicosa Creek all drain the lower part of the Cretaceous-age Pierre Shale and upper part of the Niobrara Formation, which are suspected geologic sources of uranium. Patterson Hollow had two samples that exceeded the drinking-water standard, one collected in November 2009 and the other in June 2010. Timpas Creek and Crooked Arroyo each had one sample that exceeded the drinking-water standard. Patterson Hollow, Timpas Creek, and Crooked Arroyo basins are underlain by the upper part of the Niobrara Formation. The samples with exceedences were collected in the fall, when flows in these tributaries were low.

Values of $\delta \mathrm{D}$ and $\delta^{18} \mathrm{O}$ for samples of water collected from main-stem sites in the LARB show a linear trend that plots below the GMWL (line slope of 8 ) and the Colorado LMWL (line slope of 6.3), indicating isotopic enrichment of $\delta \mathrm{D}$ and $\delta^{18} \mathrm{O}$, representing water that has been affected by evaporation and possibly evapotranspiration. The main-stem samples collected in early June 2010 are the most isotopically light samples in comparison to other samples but have been affected by evaporation and may represent water released from 
the Pueblo Reservoir. The LARB main-stem samples from October and November 2009 and August 2010 have no clear temporal groupings such as those in the UARB. Samples from Arkansas River at Las Animas, the most downstream site in the LARB, are the most isotopically heavy, suggesting possible increased surface-water evaporation and (or) increasing contribution of groundwater that has been affected by evaporation and irrigation recharge.

The tributary samples and samples from the La Junta WWTP plot below the GMWL and the Colorado LMWL, indicating that all samples are enriched in $\delta \mathrm{D}$ and $\delta^{18} \mathrm{O}$, probably as a result of evaporation. A line calculated for the tributary samples is similar to the main stem (slope of 6.16). Samples from Sixmile Creek, IR-43, Huerfano River, Crooked Arroyo, and La Junta WWTP group with little or no temporal variation (within 1 per mil unit) in the isotope concentrations, suggesting the source water for these tributaries does not undergo evaporation through irrigation return and reuse. The remaining sampled tributaries have greater temporal variation in isotopic ratios suggesting multiple evaporation cycles or, as for the main-stem sites, possibly increasing contribution of groundwater that has been affected by evaporation and irrigation recharge. However, as in the UARB, no LARB groundwater isotope samples are available for comparison to the surfacewater samples.

A Kruskall-Wallis test on periodic and synoptic DS loads in 2009-2010, excluding high streamflow samples collected in May, June, and July, indicated statistically significant (p-value 0.038 ) differences between DS loads at the main-stem sites. Using the Tukey's test for multiple comparisons, the significant differences between instantaneous DS loads at the main-stem sites were from Arkansas River near Rocky Ford to Arkansas River at La Junta. Further investigation would be needed to evaluate potential dissolved-solids source areas within the Arkansas River from Arkansas River near Rocky Ford to Arkansas River at La Junta. A Kruskall-Wallis test on selenium loads from samples collected during low-flow periods for this study from 2009-2010 indicated statistically significant ( $p$-value 0.0036) differences between loads at the main-stem sites. Using the Tukey's test for multiple comparisons, the differences between the sites were statistically significant for Arkansas River near Nepesta to Arkansas River at La Junta. The same statistical test for uranium loads in the LARB indicated the differences between the sites are significant, as with selenium, for Arkansas River near Nepesta to Arkansas River at La Junta. The river reaches from Arkansas River near Nepesta to Arkansas River at La Junta are potential source areas of selenium and uranium. Further investigation would be needed to describe the source or sources in greater detail.

To estimate the amount of ungaged contribution to DS loads from ungaged flows and other sources in the LARB, the water balance for the synoptic on November16-19, 2009, was used as the basis for calculating the concentration of DS from the ungaged sources. Calculated DS concentrations from ungaged sources for the LARB were Arkansas River near Avondale to Arkansas River near Nepesta, 1,069 mg/L;
Arkansas River near Nepesta to Arkansas River at Catlin Dam, 89.6 mg/L; Arkansas River at Catlin Dam to Arkansas River near Rocky Ford, not calculated; Arkansas River near Rocky Ford to Arkansas River at Swink, 4,926 mg/L; Arkansas River at Swink to Arkansas River at La Junta, $843 \mathrm{mg} / \mathrm{L}$; and Arkansas River at La Junta to Arkansas River at Las Animas, $1,725 \mathrm{mg} / \mathrm{L}$. The Quaternary alluvial deposits in the LARB are reported to have a median DS concentration of $1,700 \mathrm{mg} / \mathrm{L}$, and concentrations range from approximately 150 to 7,000 $\mathrm{mg} / \mathrm{L}$. The DS concentrations of ungaged sources for each of the reaches in the LARB fall within the reported range of groundwater DS concentrations, and groundwater is a plausible source for the estimated DS load. In addition to groundwater, ungaged irrigation return flow and tributaries may also be sources of the DS load; however, proportions of contributions, as in the UARB, from these sources are unknown. The ungaged streamflow, ungaged contributions to DS load, and calculated DS concentration for an assumed ungaged single source for all six reaches in the LARB are applicable only for November 16-19, 2009, and may likely vary throughout the year for different streamflow and water-quality conditions.

\section{Acknowledgments}

The authors would like to thank the many individuals who assisted in the collection and interpretation of data in support of this report. Thanks to Colorado Division of Water Resources Water Commissioners (Division 2) John VanOort, Charlie Judge, and Don Taylor (retired) for their efforts collecting periodic specific-conductance samples. Thanks also to USGS personnel Sheryl Ferguson, Shaylynn Mincic, Pamela Tello, Crystal Brown, Ryan Kopp, Russ Lewins, and Brenden Ortiz (volunteer) for their tireless efforts collecting data at all hours of the day.

\section{References Cited}

Abbott, P.O., 1985, Description of water-systems operations in the Arkansas River Basin, Colorado: U.S. Geological Survey Water-Resources Investigations Report 85-4092, 67 p.

Bureau of Reclamation, 2012, Fryingpan-Arkansas Project, accessed October 15, 2012, at http://www.usbr.gov/projects/ Project.jsp?proj_Name=Fryingpan-Arkansas\%20Project.

Cain, Doug, 1985, Quality of the Arkansas River and irrigation return flows in the lower Arkansas River valley, Colorado: U.S. Geological Survey Water-Resources Investigations Report 84-4273, 85 p. 
Cain, Doug, 1987, Relations of specific conductance to streamflow and selected water-quality characteristics of the Arkansas River Basin, Colorado: U.S. Geological Survey Water-Resources Investigations Report 87-4041, 93 p.

Cain, Doug, and Edelmann, Patrick, 1980, Selected hydrologic data, Arkansas River Basin, Pueblo and southeastern Fremont Counties, Colorado, 1975-80: U.S. Geological Survey Open-File Report 80-1185, 237 p.

Cain, Doug, Baldridge, Duaina, and Edelmann, Patrick, 1980, Waste-assimilation capacity of the Arkansas River in Pueblo County, Colorado, as it relates to water-quality guidelines and stream classification: U.S. Geological Survey WaterResources Investigations Report 80-82, 104 p.

Colorado Division of Water Resources, 2010, Cumulative yearly statistics of the Colorado Division of Water Resources-2009: Colorado Department of Natural Resources Web site, accessed February 23, 2011, at http://water.state.co.us/DWRIPub/DWR\%20Annual\%20 Reports/CYS rpt 2009.pdf.

Colorado Division of Water Resources, 2011, Colorado's surface water conditions: accessed March 28, 2011, at http:// www.dwr.state.co.us/SurfaceWater/Default.aspx.

Colorado State University, 2009, Lower Arkansas River valley research: Colorado State University Web site, accessed February 25, 2010, at http://www.csuarkriver.colostate.edu/ publications.html.

Coplen, T.B., 1993, Uses of environmental isotopes, in Alley, W.M., ed., Regional ground-water quality: New York, Van Norstrand Reinhold, 634 p.

Craig, H., 1961, Isotopic variations in meteoric waters: Science, v. 133, p. 1702-1703.

Crouch, T.M., Cain, Doug, Abbott, P.O., Penley, R.D., and Hurr, R.T., 1984, Water-resources appraisal of the Upper Arkansas River Basin from Leadville to Pueblo, Colorado: U.S. Geological Survey Water-Resources Investigations Report 82-4114, 123 p.

Dash, R.G., and Ortiz, R.F., 1996, Water-quality data for the Arkansas River Basin, southeastern Colorado, 1990-93: U.S. Geological Survey Open-File Report 95-464, 137 p.

Fishman, M.J., and Friedman, L.C., eds., Methods for determination of inorganic substances in water and fluvial sediments: U.S. Geological Survey Techniques of WaterResources Investigations, Book 5, Chapter A1, 466 p.

Gaydos, M.W., 1980, Summary of water-quality data for selected streams in Colorado: U.S. Geological Survey Open-File Report 80-682, 152 p.
Green, G.N., 1992, The digital geologic map of Colorado in ARC/INFO format: U.S. Geological Survey Open-File Report 92-0507, 9 p.

Helsel, D.R., and Hirsch, R.M., 2002, Statistical methods in water resources: U.S. Geological Survey Techniques of Water-Resources Investigations, book 4, chap. A3, 510 p., accessed February 2, 2012, at http://pubs.usgs.gov/twri/ twri4a3/pdf/twri4a3-new.pdf.

Hem, J.D., 1985, Study and interpretation of the chemical characteristics of natural water: U.S. Geological Survey Water-Supply Paper 2254, 263 p.

Kendall, Carol, and Coplen, T.B., 2001, Distribution of oxygen-18 and deuterium in the river waters across the United States: Hydrological Processes, v. 15, p. 1363-1393.

Landis, E.R., 1959, Radioactivity and uranium content, Sharon Springs Member of the Pierre Shale, Kansas and Colorado: U.S. Geological Survey Bulletin 1046-L, p. B299-B319.

Lewis, M.E., and Brendle, D.L., 1998, Relations of streamflow and specific-conductance trends to reservoir operations in the lower Arkansas River, southeastern Colorado: U.S. Geological Survey Water-Resources Investigations Report 97-4239, $48 \mathrm{p}$.

McGinn, S.M., Jansen, H.H., and Coates, T., 2003, Atmospheric pollutants and trace gases atmospheric ammonia, volatile fatty acids, and other odorants near beef feedlots: Journal of Environmental Quality, v. 32, p. 1173-1182.

Miles, D.L., 1977, Salinity in the Arkansas valley of Colorado: U.S. Environmental Protection Agency and Colorado State University, Interagency Agreement, EPA-IAG-D4-0544, $80 \mathrm{p}$.

Miller, L.D., Watts, K.R., Ortiz, R.F., and Ivahnenko, Tamara, 2010, Occurrence and distribution of dissolved solids, selenium, and uranium in groundwater and surface water in the Arkansas River Basin from the headwaters to Coolidge, Kansas, 1970-2009: U.S. Geological Survey Scientific Investigations Report 2010-5069, 59 p., accessed January 20, 2012, at http://pubs.usgs.gov/sir/2010/5069/.

Mueller, D.K., DeWeese, L.R., Garner, A.J., and Spruill, T.B., 1991, Reconnaissance investigation of water quality, bottom sediment, and biota associated with irrigation drainage in the Middle Arkansas River Basin, Colorado and Kansas, 1988-89: U.S. Geological Survey Water-Resources Investigations Report 91-4060, 84 p.

National Center for Atmospheric Research, 2011, Flood summary El Paso County, Colorado, April 29 through May 2, 1999: National Center for Atmospheric Research Web site, accessed April 21, 2011, at http://www.assessment.ucar.edu/ flood/flood_summaries/04_29_1999.html. 
Ortiz, R.F., Lewis, M.E., and Radell, M.J., 1998, Water-quality assessment of the Arkansas River Basin, southeastern Colorado, 1990-93: U.S. Geological Survey Water-Investigations Report 97-4111, 69 p.

Rantz, S.E., and others, 1982a, Measurement and computation of streamflow-v. 1, Measurement of stage and discharge: U.S. Geological Survey Water-Supply Paper 2175, 283 p., accessed February 9, 2005, at http://water.usgs.gov/pubs/ wsp/wsp 2175.

Rantz, S.E., and others, 1982b, Measurement and computation of streamflow-V. 2, Computation of discharge:

U.S. Geological Survey Water-Supply Paper 2175, 347 p., accessed February 9, 2005, at http://water.usgs.gov/pubs/ wsp/wsp 2175 .

Snow, D.D., and Spalding, R.F., 1994, Uranium isotopes in the Platte River drainage basin of the North American High Plains region: Applied Geochemistry, v. 9, no. 3, p. $271-278$.

The Ditch Project, 2011, The Ditch Project-150 years of ditches: Boulder's constructed landscape: Website accessed April 11, 2011, at http://bcn.boulder.co.us/basin/ ditchproject/?History:Water_Development_Timeline.

U.S. Department of Agriculture, 2011, National Agricultural Statistics Service 2010 cropland data layer: Website accessed July 22, 2011, at http://www.nass.usda.gov/ research/Cropland/SARS1a.htm.

U.S. Environmental Protection Agency, 2011, National primary drinking water regulations: U.S. Environmental Protection Agency Web site, accessed March 23, 2011, at .http://water.epa.gov/drink/contaminants/index.cfm\#List.

U.S. Geological Survey, 2006, Collection of water samples (ver. 2.0): U.S. Geological Survey Techniques of WaterResources Investigations, book 9, chap. A4, accessed May 23, 2011, at http://pubs.water.usgs.gov/twri9A4/.

U.S. Geological Survey, 2009, Arkansas River water-quality data: U.S Geological Survey database, accessed February 2, 2012, at http://rmgsc.cr.usgs.gov/cwqdr/Arkansas/index. shtml.

U.S. Geological Survey, 2012, National Water Information System, accessed January 10, 2012, at http://waterdata. usgs.gov/co/nwis/.

Wagner, R.J., Boulger, R.W., Jr., Oblinger, C.J., and Smith, B.A., 2006, Guidelines and standard procedures for continuous water-quality monitors: Station operation, record computation, and data reporting: U.S. Geological Survey Techniques and Methods 1-D3, 51 p., 8 attachments; accessed June 15, 2011, at http://pubs.water.usgs.gov/tm1d3.
Whittmore, D.O., Petroske, Elizabeth, Magnisun, Michael, Ahring, T.S., and Norquest, J.L., 2010, Uranium variations and loads of the Arkansas River in the High Plains, USA [abs.]: Geological Society of America Abstracts with Programs, v. 42, no. 5, p. 502.

Wilde, F.D., ed., variously dated, Field measurements: U.S. Geological Survey Techniques of Water-Resources Investigations, book 9, chap. A6, accessed January 10, 2012, at http://pubs.water.usgs.gov/twri9A/.

Zielinski, R.A., Asher-Bolinder, S., and Meier, A.L., 1995, Uraniferous waters of the Arkansas River valley, Colorado, U.S.A. A function of geology and land use: Applied Geochemistry, v. 10, no. 2, p. 133-144.

Zuellig, R.E., Sprague, L.A., Collins, J.A., and Cox, O.N. 2007, Aquatic communities and selected water chemistry in St. Vrain Creek near the City of Longmont, Colorado, wastewater-treatment plant, 2005 and 2006: U.S. Geological Survey Data Series DS 253, 30 p.

Publishing support provided by:

Denver Publishing Service Center

For more information concerning this publication, contact:

Director, USGS Colorado Water Science Center

Box 25046, Mail Stop 415

Denver, CO 80225

(303) 236-4882

Or visit the Colorado Water Science Center Web site at:

http://co.water.usgs.gov/ 


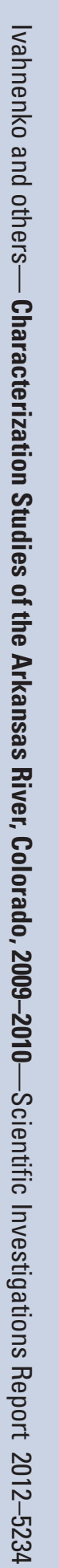

